\title{
LA MORFOLOGÍA DE LAPAROCERUS UNDATUS WOLLASTON, 1864 Y CONSIDERACIONES SOBRE LA TRIBU LAPAROCERINI LACORDAIRE, 1863 (COLEOPTERA, CURCULIONIDAE, ENTIMINAE)
}

\author{
A. Machado*
}

\section{RESUMEN}

A. Machado. 2010. La morfología de Laparocerus undatus Wollaston, 1864 y consideraciones sobre la tribu Laparocerini Lacordaire, 1863 (Coleoptera, Curculionidae, Entiminae). Graellsia, 66(2): 233-280.

Se presenta un estudio morfológico de Laparocerus undatus Wollaston, 1864 que comprende la anatomía externa e interna del adulto, incluido el canal alimentario, sistema nervioso central y sistema reproductor. También se describen las anatomías de la larva y de la pupa, hasta ahora desconocidas en el género. Los Laparocerus son curculiónidos entiminos que muestran algunos caracteres primitivos infrecuentes en el grupo. Se plantea si se justifica o no mantener la tribu Laparocerini, pendiente de revisión desde que fuera establecida por Lacordaire en 1863. Se discuten las semejanzas halladas en los caracteres imaginales y preimaginales con otros géneros y tribus, y se buscan las relaciones genéticas más cercanas empleando secuencias parciales del gen 16SrRNA de una veintena de especies, obtenidas de GenBank. Laparocerus presenta importantes caracteres singulares o combinación de ellos, y se separa claramente de los demás Entiminae estudiados, ocupando una posición posiblemente basal dentro del grupo. Se proponen algunos caracteres diagnósticos para Laparocerini: presencia de mandíbulas con prolongación dehiscente (o su cicatriz), piezas bucales fanerognatas, escapo antenal largo, ojos y escrobas no dorsales, sutura entre el primer y segundo ventrito sinuosa al medio, éste tan largo como el tercero y cuarto reunidos; fémures sin dientes, tibias mucronadas con cestilla abierta, uñas soldadas y esternito VIII masculino completamente membranoso y provisto de un pequeño espículo relicto; en la larva coinciden las antenas de base oval con sensilo en forma de almohadilla y una mala con cinco setas en su cara ventral; la pupa carece de setas mandibulares. En función de estos y otros caracteres, se discuten los demás géneros atribuidos a Laparocerini, corroborando las exclusiones hechas por otros autores recientemente, y proponiendo la exclusión de Merimnetes, Neomerimnetes y Cyrtozemia. Quedan pendientes de confirmar si son Laparocerini dos géneros africanos: Asmaratrox y Straticus. Finalmente se discute en contexto biogeográfico la conveniencia de desglosar Laparocerus en una quincena de géneros independientes, o de mantenerlo unificado como un único género con varios subgéneros.

Palabras clave: Anatomía; Curculionidae; Entiminae; Laparocerus; canal alimentario; 16SrRNA; sistema nervioso; larva; pupa; islas Canarias. 


\begin{abstract}
A. Machado. 2010. The morphology of Laparocerus undatus Wollaston, 1864 and considerations on the tribe Laparocerini Lacordaire, 1863 (Coleoptera, Curculionidae, Entiminae). Graellsia, 66(2): 233-280 (in Spanish).

This morphological study of Laparocerus undatus Wollaston, 1864 covers the external and internal anatomy of the imago, including the alimentary canal, the central nervous system and the reproductive system. The anatomy of the larva and pupa, unknown in this genus, is also described. Laparocerus are Entimin weevils that bear some primitive characters, not frequent in the group. The justification of a tribe Laparocerini, not revised since it was established by Lacordaire in 1863, is considered. Similarities of adult and preimaginal characters with those of other genera and tribes are discussed, and genetic relationships are researched using partial sequences of the 16SrRNA gen obtained from GenBank for some twenty tribe representative species. Laparocerus has important singular characters or a combination of them and is clearly separate from the other Entiminae studied. It has possibly a basal phylogenetic position within the group. Some combined diagnostic characters for Laparocerini are proposed, in particular: presence of a dehiscent mandible process (or its scar), phanerognatus mouth parts, long scape, eyes and antennal scroba not dorsal, suture of ventrites 1-2 arcuate at middle, ventrite 2 as long as 3 and 4 together, femora unarmed, tibiae mucronate with open corbels, claws connate, and VIII sternite of male membranaceous bearing a short spiculum relictum; in the larvae, antennae are cushion shaped with an oval base and the mala has five ventral setae; the pupa lacks mandibular setae. These and other characters are used to evaluate the other genera traditionally assigned to Laparocerini. Recent exclusion of some of these genera by other authors is corroborated and the removal of Merimnetes, Neomerimnetes and Cyrtozemia is here proposed. Asmaratrox and Straticus from Africa remain as Laparocerini, pending confirmation. Finally, the convenience of splitting Laparocerus into several genera or keeping it as a single genus with many subgenera is discussed in a biogeographical context.
\end{abstract}

Keywords: Anatomy; Curculionidae; Entiminae; Alimentary canal; 16SrRNA; Nervous system; Larva; Pupa; Laparocerus; Canary Islands.

\section{Introducción}

Este estudio está inspirado en el homólogo de Van den Berg (1972) dedicado a la morfología de Eremnus cerealis (Marshall, 1921), Curculionidae, Entiminiae, Tanyrhynchini. La ausencia de trabajos equivalentes en español justifica en parte este ensayo, pero su objetivo principal es profundizar más en el conocimiento del género Laparocerus Schoenherr, 1834, sobre el que el autor viene trabajando en los últimos años, y contribuir a esclarecer el concepto de la tribu Laparocerini, a todas luces insatisfactorio.

Lacordaire (1863), en su Histoire Naturelle des Insectes. Genera des Coléoptéres, establece los "Laparocérides" como grupo VII de los Otiorrhynchides, agrupando siete géneros: Elytrodon Boheman, 1843; Laparocerus Schoenherr, 1834; Aomus Schoenherr, 1834; Aprepes Schoenherr, 1847; Pholicodes Schoenherr, 1826; Epiphaneus Schoenherr, 1842 y Merimnetes Schoenherr, 1842. Posteriormente, Faust (1890) añade a esta lista Mitophorus Gerstaecker, 1855 y Edmundia Faust, 1891 (=Reitteria Faust, 1890).
Los "Laparocérides" ("Laparoceridi" in Bargagli, 1883) han sido posteriormente tratados como tribu Laparocerini (e.g. Heyne \& Taschenberg, 1907; Pierce, 1913; Lona, 1938; Alonso-Zarazaga \& Lyal, 1999), como familia Laparoceridae por Heller (1909) o como superfamilia Laparoceroidea por Ienistea (1986), sin que falten autores que no reconocen el grupo, como Seidlitz (1868) que los reúne con los "Otiorhynchides vrais", o Winkler (1932) que asigna Laparocerus a los Mylacini.

Hoy sabemos que los caracteres que justificaron este agrupamiento inicial son homoplásicos. El propio género Laparocerus, del que en aquellas fechas se conocía solo un par de especies, cuenta en la actualidad con casi dos centenas, mostrando una plasticidad morfológica extraordinaria que confirma la inutilidad de la mayoría de los caracteres empleados por Lacordaire para establecer relaciones de parentesco.

Lona (1938) excluye de Laparocerini a Elytrodon (Omiini), Aprepes (Phyllobiini), Pholicodes y Epiphaneus (Brachyderini), Edmundia (Sciaphilini) y Mitophorus (Peritelini), a la vez que añade nuevos 
géneros a la tribu, quedando el grupo como sigue: Aomus (Irán, Arabia Saudita y Siria) Laparocerus (Macaronesia) y Merimnetes (Australia), más los añadidos Aphyonotus Faust 1895 (Etiopía), Asmaratrox Heller, 1909 (Eritrea), Cyrtozemia Pascoe, 1872 (India), Lichenophagus, Wollaston 1854 (Macaronesia), Neomerimnetes Blackburn, 1900 (Australia) y Straticus, Pascoe 1886 (Zaire); nueve géneros en total.

La acepción de Laparocerini más generalizada en la actualidad es ésta de Lona, recogida directamente en el catálogo mundial de familias y géneros de Curculionoidea de Alonso-Zarazaga \& Lyal (1999), donde la tribu Laparocerini aparece bajo la subfamilia Entiminae ijunto a otras 54 más! Bien es sabido que la sistemática de los curculiónidos en general, y la de los entiminos en particular (con más de 12.000 especies), dista mucho de reflejar un esquema natural (Oberprieler et al., 2007).

Los estudios detallados de los caracteres anatómicos externos e internos (Aslam, 1961; Morimoto, 1962; Crowson, 1984; Calder, 1989; Thomson, 1992; Morimoto et al., 2006; Velázquez de Castro et al., 2007), de la morfología larvaria (Van Emden, 1952; May, 1993; Kuschel, 1995; Marvaldi. 1997, 2003; Gosik et al., 2010) de los aspectos biológicos y de las relaciones moleculares basadas en el ADN mitocondrial (Marvaldi et al., 2002; Hundsdoerfer et al., 2009; McKenna et al., 2009), han esclarecido algo la sistemática general, pero queda mucho por hacer. En la mayoría de estos trabajos se investiga la sistemática superior de Curculionoidea o de las tribus y familias conflictivas, sin que aparezcan los Laparocerini para nada. Todo parece indicar que esta tribu no ha sido revisada en su conjunto, al margen de algunas reasignaciones genéricas puntales.

Los estudios moleculares de Machado et al. (2008), aunque aún incompletos, apuntan claramente hacia una monofilia de los Laparocerus, con un clado madeirense y otro canario, incorporando el primero al género Lichenophagus como subclado interno, mientras que el subgénero Drouetius de las Azores queda completamente aislado y es promovido a género independiente (Machado, 2009), postulándose una posible relación con Peritelini o Brachyderini.

Fremuth \& Lodos (1987) transfieren Aomus a Brachyderini, pero posteriormente Yunakov \& Korotyaev (2008) demuestran su afinidad con el género Eusomomorphus Daniel, 1905 y lo trasladan a la tribu Sciaphilini. La información sobre la filia- ción real de Aphyonotus, Asmaratrox, Cyrtozemia, Merimnetes, Neomerimnetes y Straticus es inexistente o difícil de localizar. Suelen aparecer registrados como Laparocerini por defecto, o se omite su adscripción tribal, seguramente a la espera de que alguien aclare el concepto de esta tribu. A diferencia de Aomus, el aspecto externo de estos insectos, sobre todo Merimnetes y Neomerimnetes, recuerda muy poco a los Laparocerus, pero ante la inusitada variación morfotípica que se da dentro de este género, dicho criterio no es nada concluyente. No disponemos de material para poder abordar un estudio comparativo; sin embargo, al ser Laparocerus el genero tipo de los Laparocerini, un estudio morfológico en profundidad como el que se presenta aquí puede ayudar a detectar caracteres singulares del grupo o aquéllos otros que pudieran aportar algún indicio sobre las relaciones de Laparocerus con otros géneros conocidos. También se ensaya una búsqueda en GenBank del marcador mitocondrial 16SrRNA de Laparocerus undatus, por si hubiera secuencias homólogas próximas que dieran alguna pista.

El género Laparocerus se distribuye por la Macaronesia (archipiélagos de Madeira, Salvajes y Canarias) donde al parecer ha radiado profusamente, alcanzando cerca de las doscientas especies, además de contar con un representante en Marruecos occidental. La especie tipo es Laparocerus morio Boheman, 1834, de la isla de Madeira, pero se ha elegido Laparocerus undatus Wollaston, 1864 para este estudio anatómico por su gran talla y por habitar en la isla de Tenerife, lo que facilitó sobremanera la obtención de los estadios preimaginales. $\mathrm{Su}$ nombre común es "chascón gigante de Anaga" (Machado \& Morera, 2005).

\section{Material y métodos}

Los ejemplares estudiados se colectaron en el macizo de Anaga, en la isla de Tenerife (Canarias), región de la que la especie es endémica. Algunos individuos se montaron enteros o despiezados sobre etiquetas entomológicas, al modo clásico, y otros se guardaron en líquido de Scheerpeltz $(60 \%$ etanol $97^{\circ}, 38 \%$ agua destilada, $1 \%$ ácido acético glacial y $1 \%$ glicerina) para mantener las vísceras en buen estado. Para analizar la presencia de suturas no muy evidentes se utilizaron ejemplares inmaturos con la cutícula poco esclerosada y semi- 


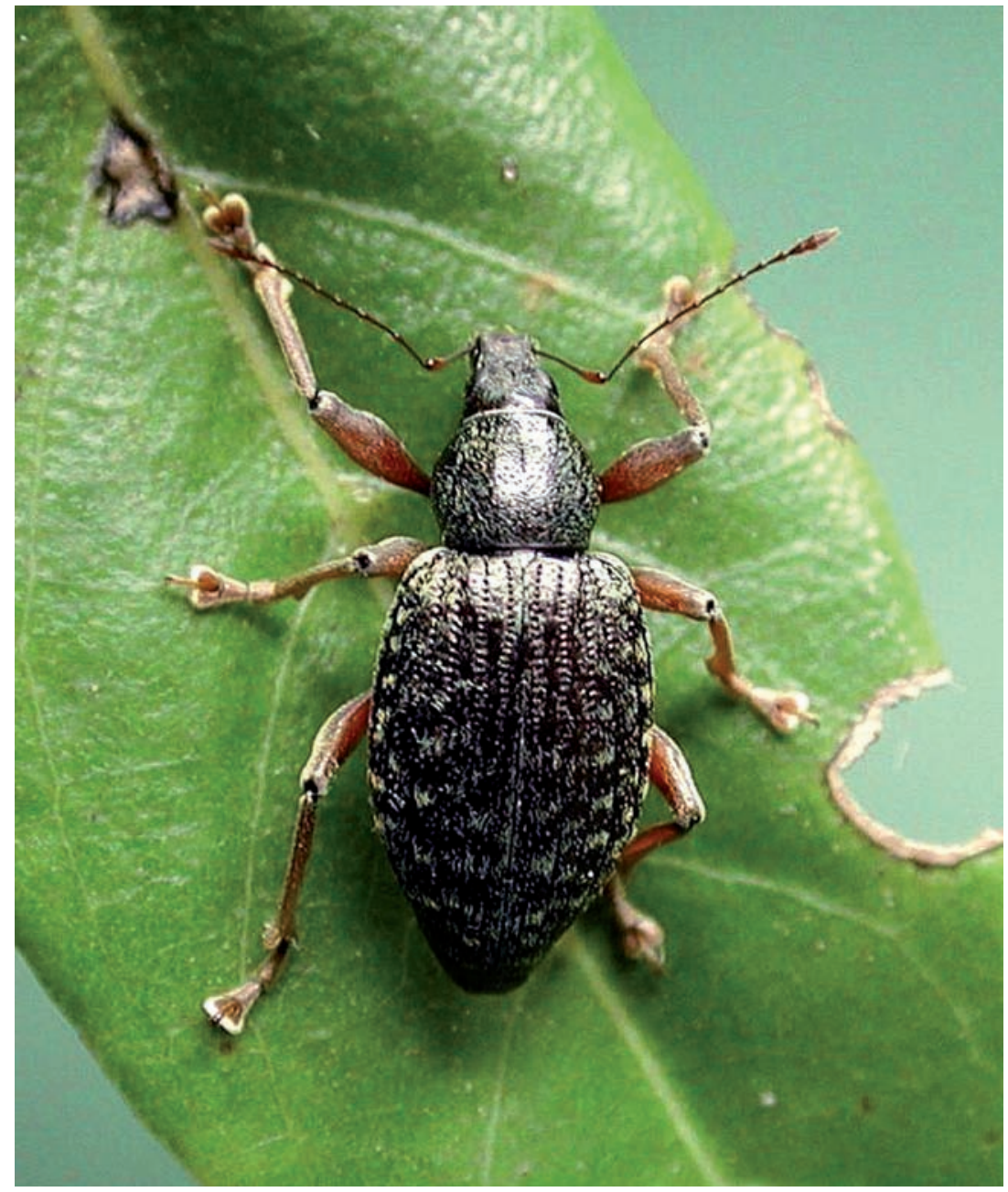

Fig. 1.- Adulto vivo de Laparocerus undatus sobre una hoja de viñátigo (Persea indica Spreng.: Lauraceae).

Fig. 1.- Living adult of Laparocerus undatus on a leaf of "viñátigo" (Persea indica Spreng.: Lauraceae).

transparente. Las larvas y un imago recién eclosionado, se encontraron al escarbar la tierra al pie de zarzas (Rubus ulmifolius) comidas por esta especie. La crisálida se obtuvo por cría a partir de las larvas, y los huevos fueron extraídos del vientre de hembras grávidas. Larvas y pupas se conservaron en líquido de Pampel (4 partes de ácido acético glacial, 6 partes de formaldehído $40 \%, 15$ partes de etanol $95^{\circ}$ y 30 partes de agua destilada).

Las disecciones se realizaron dentro de glicerina diluida. Para el estudio anatómico y dibujo se emplearon una lupa binocular y un microscopio, ambos equipados con cámara clara. Una larva, tratada con potasa al $20 \%$ para limpiar su interior, fue decapitada y rellenada con glicerina a presión para extender los tegumentos al máximo y facilitar el análisis de la disposición de los protoescleritos y estructura interna de los espiráculos. No se empleó tinción alguna, aunque sí el contraste de fases en microscopía para distinguir algunas estructuras poco evidentes. En el caso de las larvas observadas a la lupa binocular, se aplicó luz lateral sobre fondo oscuro.

La terminología empleada es básicamente la escogida o propuesta por Van den Berg (op.cit.), salvo en aquéllos casos en que se indique otra fuente. Los términos en español se han tomado mayormente del glosario de Quintanilla y Fraga (1969) o traducido directamente del inglés (Torre-Bueno, 1989; Lyal, 2010) o latín. Se han empleado números arábigos para indicar la secuencia de piezas seriadas, y los números romanos para designar su orden anatómico original en el caso de que algunas queden ocultas o se hayan perdido (segmentos del abdomen, tarsos, antenas, etc.).

Se empleó BLASTN (Zhang et al., 2000) para buscar secuencias homólogas del gen 16rRNA de Laparocerus undatus en el banco de genes (GenBank + $\mathrm{EMBL}+\mathrm{DDBJ}+\mathrm{PDB})$ que mantiene el Centro Nacional para la Información Biotecnológica (NCBI). La secuencia parcial undat $2137 \mathrm{~T}$ de 422 nucleótidos proviene de la misma serie y metodología expuestas en Machado et al. (2008), y su código de acceso es: HQ113102. El gen mitocondrial de la citocromo oxidasa II se descartó por existir demasiado pocas secuencias representativas.

La divergencia genética (p-distancia) se calculó con Mega4 (Tamur et al., 2007) después de alinear con Mafft V.5 empleando la estrategia E-INST-i (Katoh et al., 2005), y eliminar las posiciones con huecos o sin datos (408 posiciones finales). La Tabla 1 (ver Discusión, Los caracteres moleculares) 
muestra los valores de la divergencia obtenidos entre Laparocerus undatus y las demás especies seleccionadas, sus códigos de acceso a GenBank, los grupos establecidos por Marvaldi (1998) para las larvas de Entimini, y las tribus a la que pertenecen según Alonso-Zarazaga \& Lyal (1999). Los análisis filogenéticos se realizaron con MrBayes y Paup.

\section{Morfología externa del adulto}

Laparocerus undatus (fig. 1) es un insecto robusto cuya talla (medida sin contar el rostro) varía entre 9,8-12,7 $\mathrm{mm}$ en los machos $(\mathrm{n}=24)$ y $10,5-12,6 \mathrm{~mm}$ en las hembras $(\mathrm{n}=12)$. El cuerpo es de forma oblongo-elíptica, con élitros más anchos que el pronoto, moderadamente deprimidos y de hombros marcados. Carece de alas y los élitros están sólidamente encastrados a lo largo de la línea media dorsal, que constituye la sutura.

Ambos sexos presentan similar coloración. El tegumento es brillante, de color pardo negruzco, más ennegrecido o negro en el pronoto y la cabeza, y más claro o rojizo en las extremidades o las antenas. La vestimenta es muy pobre y está constituida por escasas escamitas lanceoladas adpresas, de color hialino o flavo las más anchas, con visos cobrizos o verdosos, dispuestas separadas y sin solaparse, salvo en las interestrías elitrales impares, donde se agrupan en parches que conforman un dibujo de teselas alternas (claras /oscuras) más o menos definido. Existen además escamas setiformes (fig. 6) el doble de largas que las escamitas adpresas, dispuestas erectas y sobresalientes en el tercio apical, y más inclinadas y disminuyendo de tamaño hacia la base elitral. La microescultura del tegumento varía según la región del cuerpo.

El dimorfismo sexual externo es notable: Los machos son más brillantes y estilizados que las hembras, con los élitros elípticos claramente acuminados en el tercio apical (declive suave); las protibias presentan una escotadura en la mitad apical de su cara interna y un fuerte mucrón (figura 2). Las hembras son más anchas, opacas, de élitros inflados, hombros más marcados y tercio apical apenas acuminado (declive más abrupto), presentando en la $9^{\mathrm{a}}$ interestría un callo o tumefacción alargada bastante llamativo (fig. 37); las meso- y metatibias son simples e inermes, y el último esternito abdominal es más ancho y termina redondeado (fig. 54), en vez de truncado como en el macho (fig. 55).

\section{CABEZA}

La cápsula cefálica comprende una porción posterior globular (epicráneo), abierta por detrás (foramen occipital), que se prolonga hacia delante en el rostro, más estrecho y de sección casi cuadrangular, abierto anteriormente (foramen oral) para albergar las piezas bucales en posición prognata (figs. 8-9). Existen además orificios dorso-laterales pares en los que encajan las antenas y los ojos. En la cápsula cefálica se distinguen varias regiones: la occipital, la parietal, la frontoparietal y la ventrogular.

\section{Región occipital}

La región occipital corresponde a la porción posterior del epicráneo generalmente oculta al encajar la cabeza dentro del protórax, y está generalmente mal delimitada en los coleópteros al no existir suturas bien definidas. El foramen occipital se abre en ella, y es cuadrangular, de ángulos redondeados. Una sutura postoccipital separa dos escleritos estrecho laterales o postoccipucios, además de la postgula (Hopkins, 1909), impar, que se emplaza interpuesta en el medio, en posición ventral. La membrana del cuello se une a esta sutura postoccipital (fig. 9).

\section{Región parietal}

La región parietal se corresponde con el vértex o parte dorsal de la cápsula cefálica, y las genas o parietales, que se extienden lateralmente hasta unirse a la sutura gular en la línea media ventral, excepto en el rostro (figs. 8 y 11). No se aprecian protuberancias o formaciones especiales, salvo por la profunda fóvea romboidal longitudinal que se abre en medio del vértex a la altura de los ojos (punto de anclaje del tentorio), a menudo algo prolongada hacia adelante y hacia atrás en forma de surco. En la praxis descriptiva es común referirse a ella como fóvea frontal, y a esta zona interocular como "frente" por analogía con otros animales, aunque la auténtica frente o frons en los curculiónidos está situada en la parte anterior del rostro, en la región fronto-parietal. La fóvea frontal o facial coincide con una cúspide aguda en el interior del epicráneo, formada por invaginación de la pared, que sirve de anclaje de la musculatura.

Los ojos compuestos (ca. 350 omatidios) son grandes, ovales, más curvados dorsal que ventralmente, y bastante aplastados. Si se expresa su convexidad como la relación entre la altura del casquete ocular que sobresale del perfil de la cápsula cefálica (hay que inclinar el insecto para apreciarlo bien) y el diámetro mayor del ojo, se obtiene un 10\% (un ojo 
muy prominente y completamente semiesférico tendría convexidad del $50 \%$ ). En esta especie no se aprecia bien una sutura perioftálmica y los omatidios se anclan con espículas directamente sobre el borde del orificio ocular del epicráneo. Tampoco parece existir un anillo de escleritos interpuestos ni un surco periocular profundo y destacado. El ojo está emplazado en la mitad superior de la gena, tangente al canto lateral de la frente, en posición latero-dorsal; es decir, visibles desde arriba y apenas, desde abajo.

El rostro, formado por extensión de la región parietal hacia delante, queda delimitado por la constricción que se produce, más pronunciada ventral- y lateralmente que en el vértex (apenas una ligera inflexión). Como en la mayoría de los Entiminae, el rostro es corto y, en esta especie, cuadrangular en vista dorsal, con los márgenes dorsales angulosos bien definidos y paralelos (fig. 8). Su sección en el medio es ligeramente trapezoide, más ancha basal que dorsalmente. A efectos topográficos, la parte dorsal de esta región parietal del rostro se denomina epifrons (DuPorte, 1960), y en L. undatus no forma canal con los márgenes levantados; en su tramo distal existe a lo sumo una pequeña naveta o zona algo deprimida y lisa. Lateralmente, en el extremo antero-superior, se abre el acetábulo antenal en medio de un recinto articular más amplio para permitir el movimiento de la base de la antena. Esta escroba anterior ("swinging fossa" s. Morimoto et al., 2006) es visible desde arriba, está abierta por delante y delimitada externamente por el pterigio; hacia atrás se prolonga y abre en forma triangular (escroba posterior), siendo poco profunda al comienzo (en esta especie) y luego muy superficial; su margen superior se dirige más o menos hacia la mitad del ojo, sin alcanzarlo, y el margen inferior coincide con el surco escrobal que es breve y discurre inclinado hacia atrás y abajo, desvaneciéndose sin alcanzar el margen ventral del rostro (fig. 11). La pregena o parte latero-ventral del rostro delimitada por el surco escrobal (Hopkins, 1909), es poco abultada y su margen anterior es recto, prácticamente en vertical, sin formar un seno pleurostomal; el pterigio, o lámina auriculariforme que enmarca inserción antenal por fuera y configura el canal escrobal anterior, es corto, avanzado y abierto por delante; en vista dorsal sobresale poco.

El tegumento presenta algunas escamitas, punteado superficial y microestrías longitudinales y conspicuas a lo largo del vértex, ausentes en el occipucio y curvadas o trasversales sobre sienes y genas, aunque menos marcadas.

\section{Región fronto-parietal}

En curculiónidos, la región fronto-parietal comprende la porción anterior del rostro entre el vértex (epifrons) y el foramen oral que alberga las piezas bucales (figs. 10-11). Su ontogénesis se atribuye a la pérdida de individualidad del clípeo y a la fusión de varios escleritos, aunque sigue habiendo dudas ya que las suturas faciales han desaparecido ( $v$. Snodgrass, 1935; DuPorte, 1960; Van den Berg, 1972). El epistoma es la parte más avanzada, originado por fusión del clípeo y labro. En Laparocerus undatus es triangular, algo escotado y queda bien delimitado por la quilla epistomal en forma de "V" que lo separa de la auténtica frente (frons). Ésta es estrecha -no forma una placa rostral lisa diferenciada- y porta tres setas rígidas flanqueando al epistoma por los lados y formando conjunto con otras 5 dispuestas sobre los ángulos latero-anteriores del rostro. Morimoto et al. (2006) emplean el término de parepistoma para designar esta región. El conjunto epistoma-parepistoma se diferencia bien en el extremo del rostro de los Laparocerus por estar inclinado hacia abajo en relación al plano del vértex, y por presentar usualmente una microescultura diferenciada (microrreticulación poligonal diminuta en esta especie) y los márgenes laterales algo elevados.

En trabajos anteriores sobre Laparocerus he empleado con sentido meramente topográfico, el término de prorrostro, para referir a esta parte dorsal e inclinada, y el de metarrostro para el resto del rostro (Machado 2007, 2008a, b, etc.). Estos términos fueron acuñados por Damoiseau (1967) para curculiónidos fanerognatos (Brentidae) con el obje-

Figs. 2-6.- Aspecto general del imago. 2) Imago $\sigma^{7}$ en vista dorsal. 3) Tórax y abdomen en vista ventral (patas derechas retiradas). 4) Cabeza en vista ventral. 5) Imago + en vista lateral. 6) Escamas.

Figs. 2-6.- General aspect of imago. 2) Imago $\sigma^{7}$ in dorsal view. 3) Thorax and abdomen in ventral view (right legs removed). 4) Head in ventral view. 5) Imago $ᄋ$ in lateral view. 6) Scales. 


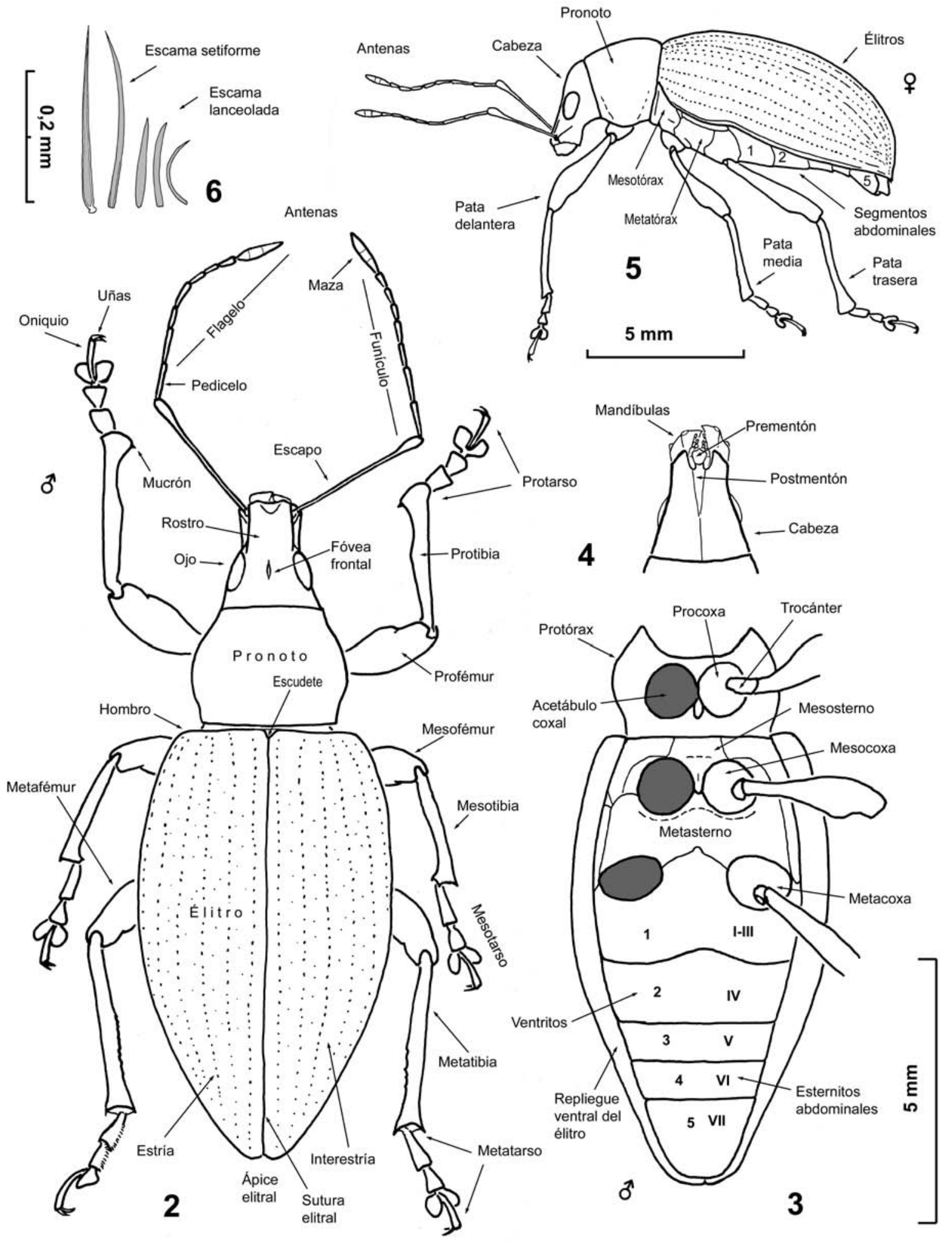


to de distinguir entre la porción del rostro anterior a la inserción de las antenas (prorrostro) y la posterior (metarrostro). En Laparocerus la separación de la región parietal de la fronto-parietal no coincide del todo con el punto exacto de inserción de las antenas, pero como quiera que esta distinción resulta útil en la praxis descriptiva, parece justificado redefinir los términos de prorrostro y metarrostro en el sentido expuesto aplicable a curculiónidos de morro corto. La epifrons (DuPorte, op. cit.) coincidiría con el dorso del metarrostro.

\section{Región gular y cara ventral del rostro}

En el epicráneo de Laparocerus, como ocurre en la mayoría de Curculionoidea, las genas se unen ventralmente a lo largo de la línea media dejando una sutura gular (fig. 9). No existen gula ni pregula, y la sutura gular se une directamente a la sutura postoccipital. La estrecha postgula impar que orla el foramen occipital en esta zona se origina por fusión de escleritos cervicales y no tiene nada que ver con la gula (v. Lyal, 1995). En el metarrostro, los parietales (gena y pregena) se separan hacia delante a partir del punto medio de su base, que coincide con la fóvea tentorial posterior, dejando un estrecho espacio triangular que ocupa el postmentón ( $s$. Morimoto 1962). Existe además una pequeña fóvea hipostomal imprecisa en la subgena, a cada lado del postmentón y más o menos a mitad del rostro.

El tegumento en toda la cara ventral es más brillante, con escamitas pequeñas salvo en las pregena y subgena, donde son grandes, y sobre todo en el postmentón, que está densamente tapizado de ellas, además de presentar un par de setas muy largas en su parte distal. Las setas largas del margen anteroventral de las pregenas disminuyen en tamaño hacia atrás.

\section{Tentorio}

En Laparocerus undatus el tentorio arranca como una lámina sagital única fusionada a lo largo de la sutura gular, que parte de la fovea tentorial posterior hasta unirse a la pared ventral del occipucio; luego, en su borde interno y a todo lo largo se abre en dos brazos, igualmente laminares, que enlazan con el borde del foramen occipital en su mitad ventral (fig. 12). Como es común en Curculionoidea, los brazos tentoriales anteriores no están desarrollados.

\section{Piezas bucales}

Las piezas bucales de los Entiminae son las mandíbulas, maxilas, labio e hipofaringe (hypopharynx), acomodadas en la cavidad gnatal u oral (fig. 10), en la parte delantera del rostro; no existe labro,

Mandíbulas (figs. 14-15).- En Laparocerus las mandíbulas son cortas, cuadrangulares e iguales en ambos sexos; carecen de mola y están dispuestas para moverse en un plano casi horizontal, apropiado para el mordisqueo. Al cerrarse, la mandíbula izquierda solapa a la derecha. El borde masticador superior cuenta con un diente apical prominente y otro basal menos conspicuo, a los que se suma un tercer diente ventral en el borde inferior; todos sufren bastante desgaste en la vida del adulto. En la cara lateral externa existe media docena de setas mandibulares (3 largas y 3-4 más cortas) y en el extremo anterior externo, en posición fronto-ventral, se aprecia bien la huella o cicatriz (plana, no pedunculada en L. undatus) de la base de la prolongación mandibular caduca. Casi todos los Entiminae cuentan con este tipo de prolongación falciforme en las mandíbulas de la pupa, que es temporal y emplea el recién transformado imago para abrirse paso, desprendiéndose luego, a veces, pasados unos días. No es infrecuente observar Laparocerus inmaturos con el característico apéndice falciforme, sin denticula-

Figs. 7-20.- Cabeza del imago. 7) Antena con detalle de la base del escapo y de la maza. 8) Capsula cefálica (con ojos) en vista dorsal. 9) Cabeza sin antenas en vista ventral. 10) Cabeza sin piezas bucales de frente, mostrando la abertura gnatal. 11) Cabeza sin antenas en vista lateral. 12) Corte coronal (latero-lateral) de la cápsula cefálica mostrando el tentorio occipital. 13) Hipofaringe en vista dorsal. 14) Mandíbulas en vista dorsal. 15) Mandíbula izquierda en vista ventral. 16) Mandíbulas con la prolongación dehiscente en individuo recién eclosionado. 17) Labio en vista ventral. 18) Labio en vista lateral. 19) Prementón en vista dorsal. 20) Maxila izquierda en vista dorsal.

Figs. 7-20.- Head of imago. 7) Antenna and details of base of scape and of club. 8) Head capsule (with eyes) in dorsal view. 9) Head without antennae in ventral view. 10) Head without mouth pieces in frontal view, showing gnatal cavity. 11) Head without antennae in lateral view. 12) Transversal cut of head capsule showing occipital tentorium. 13) Hypopharynx in dorsal view. 14) Mandibles in dorsal view. 15) Left mandible in ventral view. 16) Mandibles with dehiscent process in recently hatched specimen. 17) Labium in ventral view. 18) Labium in lateral view. 19) Prementum in dorsal view. 20) Left maxilla in dorsal view. 


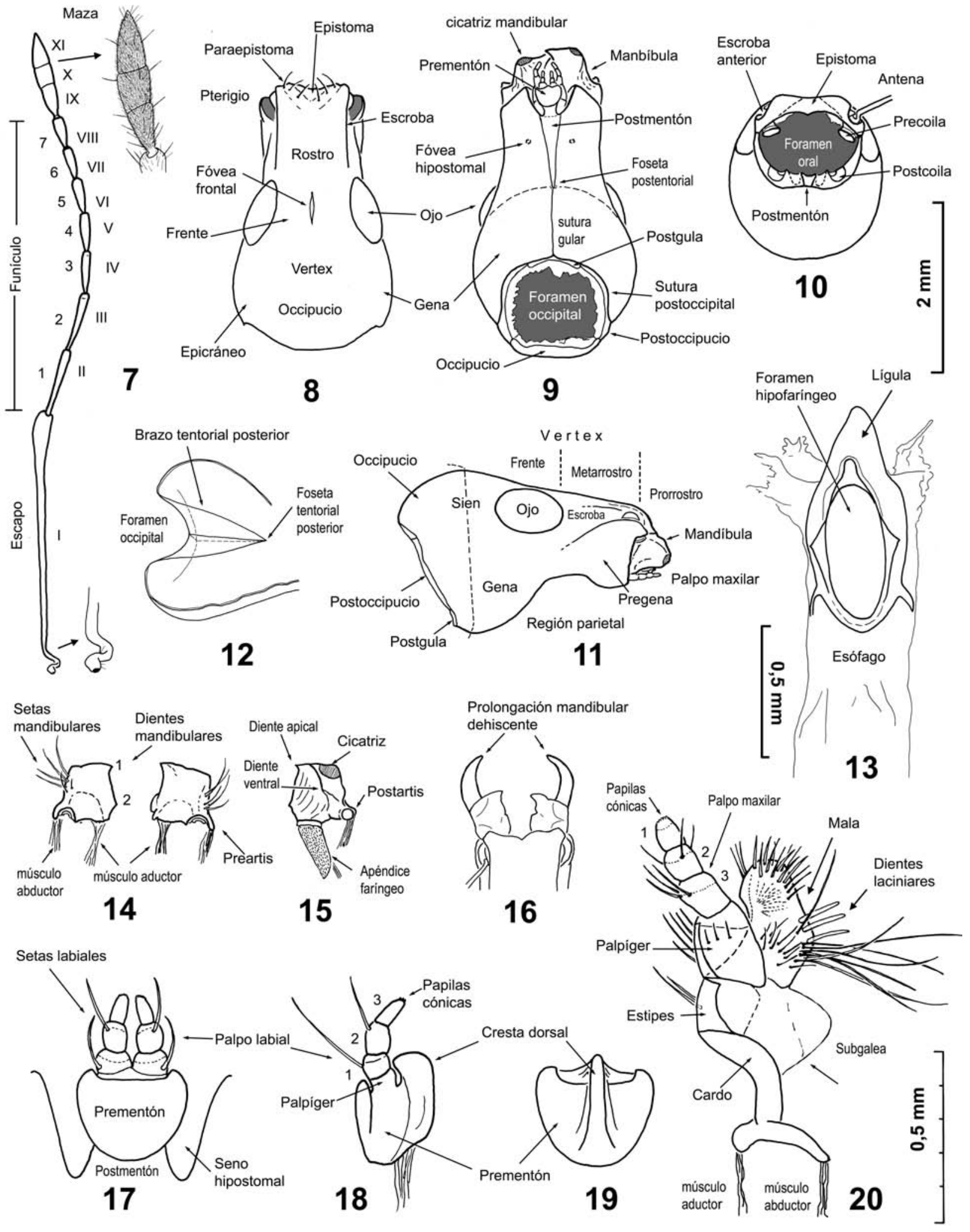


ciones en su cara interna, y tan largo como la parte basal (fig. 16). La articulación dorsal (preartis) de la mandíbula consiste en un cóndilo arqueado ahuecado que delimita un acetábulo en el que encaja la precoila del rostro. La articulación ventral se establece a través de un cóndilo globular muy prominente situado en el ángulo basal externo de la mandíbula, el cual encaja en el acetábulo cóncavo de la postcoila, en el margen antero-ventral del rostro (fig. 10). Las mandíbulas están agarradas en su ángulo basal interno por músculos aductores, mucho más robustos que los abductores, situados próximos a su ángulo basal externo. La pieza membranosa que acompaña a la musculatura es estrecha en los abductores, y laminar y ancha en los aductores. Existe además, como es característico en los Curculionoidea, el apéndice faríngeo, lengüeta membranosa tapizada de minúsculas espículas que, perteneciendo a la faringe (Sting, 1936), se ancla en la base de la mandíbula, y se extienden hacia el foramen hipofaríngeo (fig. 15); en Laparocerus undatus es tan largo como la mandíbula.

Maxilas (fig. 20).- Las maxilas en Rhynchophora han rotado para poder moverse dentro de la boca en sentido vertical, de modo que su cara dorsal deviene en externa, y la ventral en interna. Cada maxila está compuesta por varias piezas. El cardo es la más basal, no muy larga, glabra, curvada y bifurcada en la base a modo de herradura abierta y oblicua (parartis), a cuyos brazos se agarran terminalmente los músculos abductores y aductores. La concavidad del parartis se articula con las paracoilas de la cápsula cefálica. El cardo se une por su extremo distal al estipe, que es cuadrangular y porta dos setas, y éste al palpígero, algo mayor y con varias setas en su cara externa y unas pocas, menores, en la interna. La mala -formada por fusión de la gálea y lacinia- es amplia, laminar y está unida lateralmente a la base del palpígero. Cuenta con un campo distal (región galear) de abundantes setas cortas agregadas, y con otro más proximal de setas menos robustas (región laciniar); además, junto a este último y junto al margen existe un grupo de setas flageliformes muy largas, y a lo largo del margen interno una hilera de robustas setas laminares, rígidas, romas y encajadas en pequeños zócalos, denominadas dientes laciniares. En Laparocerus undatus, el número de estos dientes varía bastante (3-6) y pueden internarse en la región galear. Por debajo de la mala y unida al estipe y mitad distal del cardo existe en esta especie una lámina poco esclerotizada (subgálea) a través de la que se estable- ce la unión de la maxila con la hipofaringe. Finalmente, y asentado sobre el extremo del palpígero, se encuentra el palpo maxilar, compuesto de tres artejos, con una zona anular más esclerotizada; el primero porta 3 setas en el borde externo distal de dicho anillo; el segundo 3 setas formando corona, y el tercero carece de setas pero culmina en el característico grupito de diminutas papilas cónicas sensoriales.

Labio (figs. 12-19).- El prementón es la pieza cordiforme, gruesa y ventralmente lisa emplazada en el espacio hipostomal abierto entre las pregenas, sin que llegue a tocarlas, de modo que las bases de las maxilas son perfectamente visibles por el hueco que queda a ambos lados del prementón (condición fanerognata sensu Lacordaire, 1863). El prementón se asienta sobre una prolongación peduncular estrecha y corta de la pieza alargada que encaja entre las subgenas y se extiende estrechándose hasta la fóvea tentorial posterior. Esta pieza se ha originado en Rhynchophora hipotéticamente por la fusión del mentón y submentón y es designada postmentón por Ting (1936) mientras que otros autores la interpretan como el submentón. El postmentón presenta dos setas largas próximas a la base de su pedúnculo apical, además de varias escamitas setiformes a todo su largo. El prementón carece de setas en su cara ventral, y en la cara dorsal interna desarrolla una gruesa quilla mediana longitudinal, cuyo borde anterior sobrepasa el de la cara ventral; entre ambas caras queda un espacio ocupado por un esclerito deprimido interpretable como palpígero (fig. 18). Sobre este último se asientan los dos palpos labiales, que son contiguos y están formados por tres artículos rígidos, progresivamente más largos y estrechos; los dos primeros con una única seta, y el terminal con unas pocas papilas cónicas en el ápice, similares a las del último artejo del palpo maxilar.

Hipofaringe (fig. 13).- La hipofaringe (hypopharynx) es una pieza oval flexible que ocupa la parte ventral de la cavidad oral y enmarca la abertura del canal alimentario. Se une mediante membranas al prementón por la base de su cara interna, y lateralmente a la subgálea de las maxilas; por delante se prolonga en una corta lígula membranosa cuyas paredes internas, así como las del canal alimentario en esta zona, están tapizadas de espículas microscópicas y sedosas, dirigidas hacia atrás.

\section{Antenas}

Las antenas son geniculadas, muy largas y delgadas (fig. 7). Cuando el insecto las recoge reposan 
en el canal escrobal y quedan por debajo del ojo. Están compuestas por once artejos o antenómeros repartidos en tres secciones (s. Hopkins, 1909): escapo, funículo y maza. El escapo es el primero y más largo, rectilíneo y delgado salvo en su quinto apical, donde se engruesa hasta el doble de su diámetro (escapo capitado). Dispuesto hacia atrás, rebasa la cabeza. Su extremo basal se acoda hacia abajo para recurvarse brevemente hacia arriba, de modo que encaja en el foramen antenal que se abre protegido por un corto saliente a modo de visera, en la pared lateral del rostro. Con esta disposición el escapo puede balancearse en la escroba anterior de adelante hacia atrás. El funículo lo componen siete desmómeros (s. Alonso-Zarazaga, 1989), siendo el primero el pedicelo que pivota y hace ángulo en el extremo ahuecado del escapo. Solo el escapo y el pedicelo presentan muculatura propia, los siguientes desmómeros carecen de ella y representan el flagelo de otras antenas (Imms, 1970). Éstos son progresivamente más cortos, y a partir del $3^{\circ}$ algo más anchos distalmente. La maza es fusiforme, elíptica, no mucho más ancha que el desmómero precedente, y está formada por tres segmentos, terminando el último en una punta breve de tegumento diferenciado por una constricción o annulus.. El tegumento en el escapo es liso y porta escamitas setiformes tumbadas, más largas y destacadas en el engrosamiento apical. En los desmómeros del funículo las escamitas y algunas setas subapicales están más levantadas. La maza (fig. 7, detalle) está cubierta por una pubescencia sedosa y corta, de la que emergen algunos pelos sensoriales radiales, y un ligero agrupamiento justo en el ápice.

\section{TÓRAX}

El tórax está compuesto por tres segmentos, el protórax, individualizado y con movimiento libre, y el conjunto del meso y metatórax, unidos para formar el llamado pterotórax que, visto desde arriba, queda oculto bajo los élitros, salvo por el escudete. Todos los Laparocerus carecen de alas funcionales.

\section{Protórax}

El protórax es dolioliforme (= forma de barril), abierto por delante para acoger la cápsula cefálica, y abierto por detrás, donde se acopla el mesotórax (fig. 3). Es más ancho que largo, con la máxima anchura hacia la mitad, y mucho más corto ventralque dorsalmente (fig. 21). El pronoto abarca el dorso y los flancos como pieza única; sus lados son bastante convexos, con ligera sinuosidad preangular, más estrechados por delante que por detrás, donde los ángulos laterales son subrectos; sus márgenes carecen de reborde y el anterior es recto en toda su extensión, sin lóbulos oculares o prominencias equiparables. No existe quilla mediana y en vista lateral, se aprecian unas impresiones basales que demarcan los márgenes más constreñidos.

En la cara ventral del protórax no hay suturas notopleurales (pronoto-propleura), tal como corresponde a todo Polyphaga (fig. 22). Las dos amplias fosas coxales (acetábulos) son contiguas, están emplazadas al medio y quedan cerradas por detrás por el arco o puente post-coxal, cuyo origen notal o pleural no es fácil de discernir (pleuras invaginadas, fundidas o desaparecidas). Su separación del margen anterior es mucho menor que la del posterior y existe un débil surco prosternal paralelo al borde anterior (surco collar). En el espacio intercoxal posterior se desarrolla una pequeña apófisis o gránulo que bien pudiera representar una reminiscencia de los escleritos esternales o lo que Hopkins (1909) designa como esternelo. Existe una impresión posterior que orla las procoxas y la apófisis intercoxal (¿huella de la sutura pleuroesternal o simple reborde?), además de otra paralela al borde posterior que podría señalar la línea de fusión de los estrechos epímeros. El canto de las piezas que demarcan los orificios anterior y posterior del protórax está orlado en todo su perímetro por un cepillo de pelitos claros.

El tegumento en el dorso presenta punteado doble, fino, denso y superficial, siendo los puntos mayores bastante más escasos y no más del doble de grande que los pequeños.

\section{Mesotórax}

El mesotórax se encuentra íntimamente unido al metatórax y es casi la mitad de largo que éste (figs. 26 y 27). El área mesotergal queda parcialmente oculta por el pronoto y es preciso retirarlo para que quede expuesta. La ocupa una pieza cordiforme muy amplia (fig. 29), compuesta por el pre-escudo (prescutum), escudo (scutum) y el escudete (scutellum). El pre-escudo es la pieza superior y convexa, surcada al medio y a todo su largo, y truncada por detrás, donde se acopla al pequeño escudete triangular, que queda emplazado entre los dos élitros (fig. 31). En gran parte de su superficie existen puntos con pequeños pelos tumbados, que quedan 
expuestos cuando el animal se estira y separa el protórax del mesotórax. La disposición del pre-escudo (figs. 33-34) impide que su borde anterior, así como la sutura antecostal y prefragma, sean visibles desde arriba (no existe postfragma). En los extremos laterales anteriores se desarrolla una pequeña apófisis donde se insertan las membranas conectivas de los élitros (fig. 30). La sutura posterior del pre-escudo es difícil de reconocer y, aparentemente, el escudo queda oculto bajo el pre-escudo. La pieza que, en vista dorsal, asoma por debajo de los márgenes oblicuos posteriores del pre-escudo pertenece al escudete, de modo que el escudo queda interrumpido al medio por detrás.

El orificio anterior del protórax está demarcado dorsalmente por el escudo, ventralmente por el premesosterno, y en cada lado por un preepisternito (fig. 28). Estos últimos escleritos pleurales se engrosan progresivamente hacia su extremo terminal, que es muy grueso, esclerosado, truncado y algo ahuecado, sirviendo de receptáculo de apoyo a la apófisis articular del élitro. El área esternal entre los preepisternitos la ocupa un grueso reborde anterior del mesosterno que presenta el mismo grosor que éstos y mantiene el margen ventral anterior del segmento rectilíneo (no cóncavo); no existe sutura posterior por lo que cabe descartar que se trate del promesosterno (fig. 27).

El mesosterno ocupa, pues, el espacio entre las cavidades coxales y el borde anterior; se prolonga en arco a ambos lados de las coxas (hasta el nivel de su mitad), así como entre ellas, formando el saliente inter-mesocoxal, que es estrecho y algo aquillado (fig. 27). El declive precoxal del mesosterno es pronunciado (ver de perfil, fig. 26). A cada lado del mesosterno y separados por la fina sutura mesopleurosternal, se encuentran los mesepisternitos que, aunque visibles también en la cara ventral, ocupan los flancos del segmento y están delimitados dorsalmente por la sutura pleural que los separa de los estrechos y alargados mesepímeros. Éstos son los escleritos pleurales que rematan la caja mesotorácica dorso-lateralmente, y quedan ocultos bajo el repliegue lateral de los élitros, salvo por su extremo posterior que asoma brevemente en la cara ventral, alcanzando el ángulo anterolateral del metasterno (fig. 3), como es típico en curculiónidos ápteros (Morimoto, 1962).

Las cavidades mesocoxales se abren a partir del margen posterior del mesosterno, son amplias, semicirculares y abiertas por detrás.

\section{Metatórax}

El área metatergal queda visible cuando se retiran los élitros. En los curculiónidos ápteros suele ser membranosa y contar con algún esclerito muy reducido o carecer de ellos (Blatchley \& Leng, 1916). En Laparocerus undatus existe una larga y fina tira esclerosada y quebrada que parte de la apófisis alar del metaepisternito (fig. 51) y se extiende por todo el margen metatergal anterior. Se trata del cordón axilar (s. Snodgrass, 1927) o de una sucesión de escleritos tergales que podría designarse como "cíngulo metatergal". Centrados sobre la mediana del cuerpo y muy próximos a él existe un par de escleritos postmarginales digitiformes -muy cortos en esta especie- dirigidos hacia atrás (fig. 53), que podría representar lo que queda de los postnotos.

El metasterno es más amplio que el mesosterno y su forma recuerda al símbolo de Batman (fig. 27). Las amplias escotaduras pares del margen anterior y del posterior coinciden, respectivamente, con los acetábulos meso y metacoxales. La distancia entre la meso y la metacoxa es menor que el diámetro longitudinal de la coxa, característico de las especies ápteras. El margen anterior está gruesamente rebordeado de lado a lado y siguiendo las inflexiones de las coxas, lo que Matsuda (1970) designa como surco paracoxal; en el margen posterior solo existe una impresión paralela a las metacoxas, aunque

Figs. 21-28.- Tórax del imago. 21) Protórax en vista lateral. 22) Protórax en vista ventral (procoxa derecha retirada). 23) Protórax y pata izquierda en vista posterior (cuerpo posterior retirado). 24) Base del metendosternito entre las metacoxa, vista dorsal (abdomen retirado). 25) Metendoesternito entre las metacoxas en vista posterior (abdomen retirado). 26) Pro-, meso- y metatórax en vista lateral, con los élitros retirados. 27) Meso- y metatórax en vista ventral. 28) Mesotórax en vista frontal (protórax retirado).

Figs. 21-28.- Thorax of imago. 21) Prothorax in lateral view. 22) Prothorax in ventral view (right procoxa removed). 23) Prothorax and left leg in rear view (hind-body removed). 24) Base of metendosternite between metaxocae, dorsal view (abdomen removed). 25) Metendosternite between metacoxae in posterior view (abdomen removed). 26) Pro-, meso- and metathorax in lateral view, without elytra (removed). 27) Meso- and metathorax in ventral view. 28) Mesothorax in frontal view (prothorax removed). 


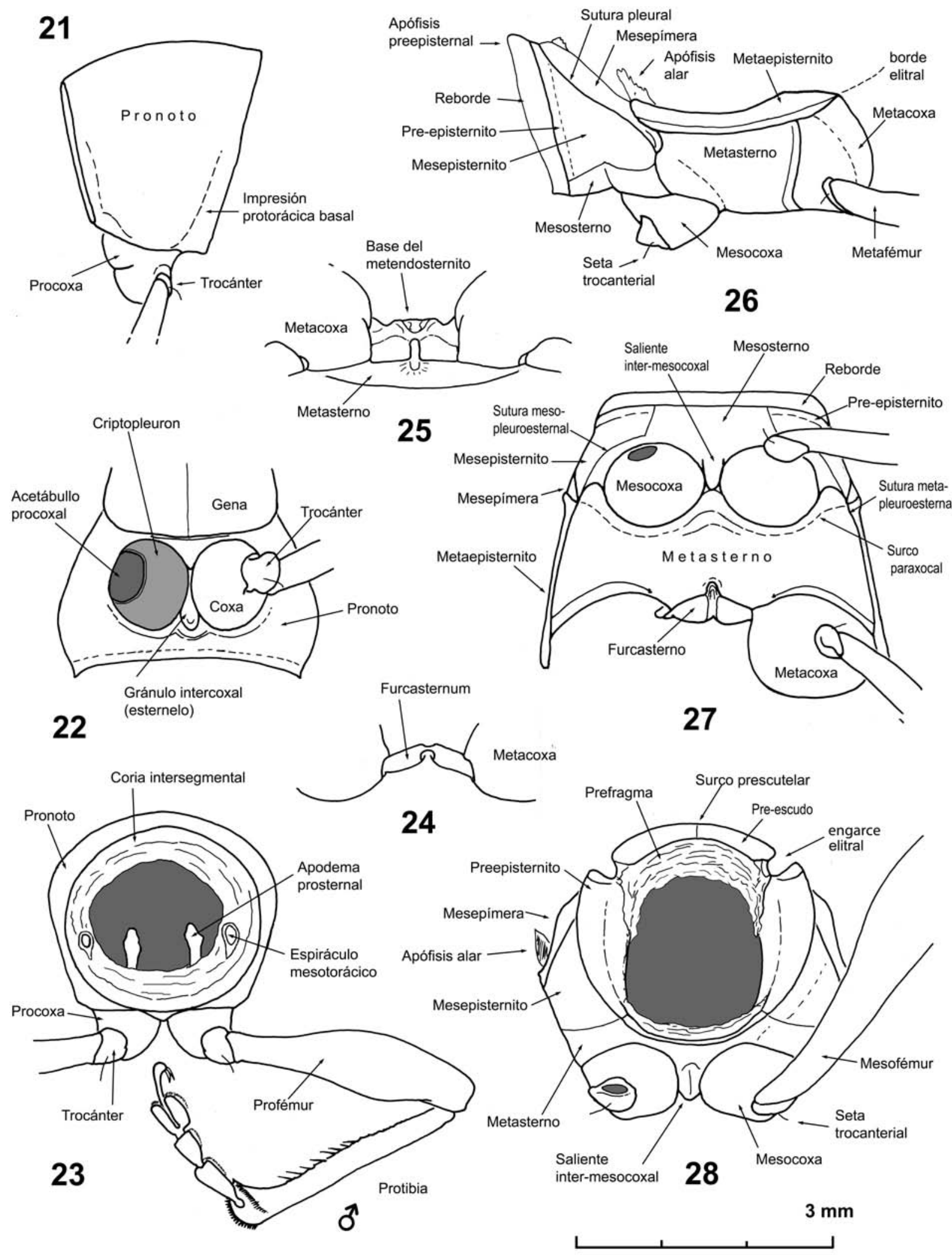


interrumpida al medio. El metasterno lo flanquean los metaepisternitos, separados por la sutura metapleurosternal, que es completa. Éstos son escleritos estrechos y alargados que rebasan el metasterno, alcanzando la cavidad metacoxal. A todo su largo se aprecia una carena sobre la que descansa el élitro, tapando la mitad dorsal. En su extremo posterior se encuentra el metaepímero fusionado sin solución de continuidad, aunque en ejemplares inmaturos se puede apreciar la sutura pleural oblicua que los une. El metaepímero es corto, bordea la cavidad coxal y alcanza el primer esternito abdominal.

Las cavidades metacoxales son ovales y más amplias que las mesotorácicas, están bastante separadas entre sí, y alcanzan lateralmente el metaepímero. El saliente metacoxal posterior apenas se interna entre las coxas, donde se produce un hundimiento foveiforme, a menudo amplio, que coincide con el anclaje del metendosternito. Cuando se retira el abdomen, se puede observar una sutura transversal (fig. 24) que le separa del estrecho furcasterno, al que se encuentra unida la base del metendosternito (figs. 25 y 51). El estrecho canal sagital que presentan estas piezas al medio es donde se articula, a modo de charnela, el saliente anterior del primer ventrito abdominal.

\section{Espiráculos}

Los espiráculos torácicos son algo más grandes que los abdominales, y presentan válvula reguladora de su apertura. El par mesotorácico se encuentra emplazado en la membrana conectiva entre el protórax y el mesotórax (fig. 23), mientras que el metatorácico se sitúa a nivel de la mitad del metasterno, algo distante del esclerito y casi sobre el borde posterior de la membrana metatorácica (fig. 51).

\section{Endosqueleto}

En el interior del protórax se distinguen dos grandes endoscleritos, los apodemas prosternales (fig. 23), que nacen de la vaina que conforma el acetábulo procoxal formada por el criptopleuron (Hlávac, 1972).

Los endoscleritos del pterotórax son más complejos (fig. 51). En las paredes laterales existen invaginaciones entre los pleuritos que constituyen los apodemas laterales o endopleuritos. La llamada quilla pleural está muy poco desarrollada, como corresponde a un insecto áptero, y se une al extremo del endopleurito metaepisternal para formar la apófisis alar, que emerge oblicuamente de la caja torácica (fig. 26). El endopleurito metaepisternal conforma a lo largo del metaepisternito un canal donde se insertan las membranas tergales. El mesepímero también está acanalado y su margen dorsal es delgado y laminar.

En el mesotórax, el mesosterno y los mesepisternitos están reflejados hacia dentro en su margen anterior. A cada lado existe un mesendosternito acintado (apodema mesosternal) que parte de un contrafuerte de la pared interna del acetábulo mesocoxal, y se extiende suspendido hacia delante para formar un codo (con laminillas laterales poco desarrolladas) y terminar próximo a la pared lateral de la caja torácica, a la que se fija mediante ligamentos al mesepímero. El extremo posterior del mesepímero se une internamente a la base de la vaina coxal, constituyendo un recio puente endopleural. Las vainas mesocoxales también se unen entre sí por su cara interna formando un amplio arco, que queda hueco por debajo, dejando una suerte de túnel sobre el mesosterno, por el que pasa el cordón nervioso.

Los metendosternitos se han fusionado en una pieza impar en forma de $\mathrm{Y}$ o furca (fig. 51), unida firmemente por su amplia base bifurcada al esternelo, designado por ello como furcasterno (encajado entre las metacoxas); su tronco es alto y estrecho, con los lados ventralmente convergentes hacia delante, mientas que dorsalmente y hacia la mitad (cruz) se

Figs. 29-38.- Piezas escutelares, élitros y rudimento alar. 29) Piezas escutelares en vista dorsal. 30) Detalle del engarce elitral-escutelar en vista frontal. 31) Disposición de las piezas escutelares sobre la base elitral, en vista frontolateral. 32) Piezas escutelares en vista lateral. 33) Disposición del escudete y base elitral en vista lateral. 34) Élitros $\sigma^{7} \sigma^{7}$ en vista dorsal. 35) Élitros $\sigma^{7} \sigma^{7}$ en vista lateral. 36) Detalle de la terminación del abdomen $\sigma^{7}$. 37) Detalle de la estriación en el ápice elitral ㅇ. 38) Rudimento del ala metatorácica izquierda.

Figs. 29-38.- Scutellar pieces, elytra and rudimentary wings. 29) Scutellar pieces in dorsal view. 30) Detail of elytral-scutellar coupling in frontal view. 31) Placement of scutellar pieces on elytral base, in frontolateral view. 32) Scutellar pieces in lateral view. 33) Placement of scutellar pieces on elytral base, in lateral view. 34) Elytra $\sigma^{7} \sigma^{7}$ in dorsal view. 35) Elytra $\sigma^{7} \sigma^{7}$ in lateral view. 36) Detail of hind part of abdomen $\sigma^{\pi}$. 37) Detail of striae disposition of elytral apex 오. 38) Rudiment of left metathoracic wing. 


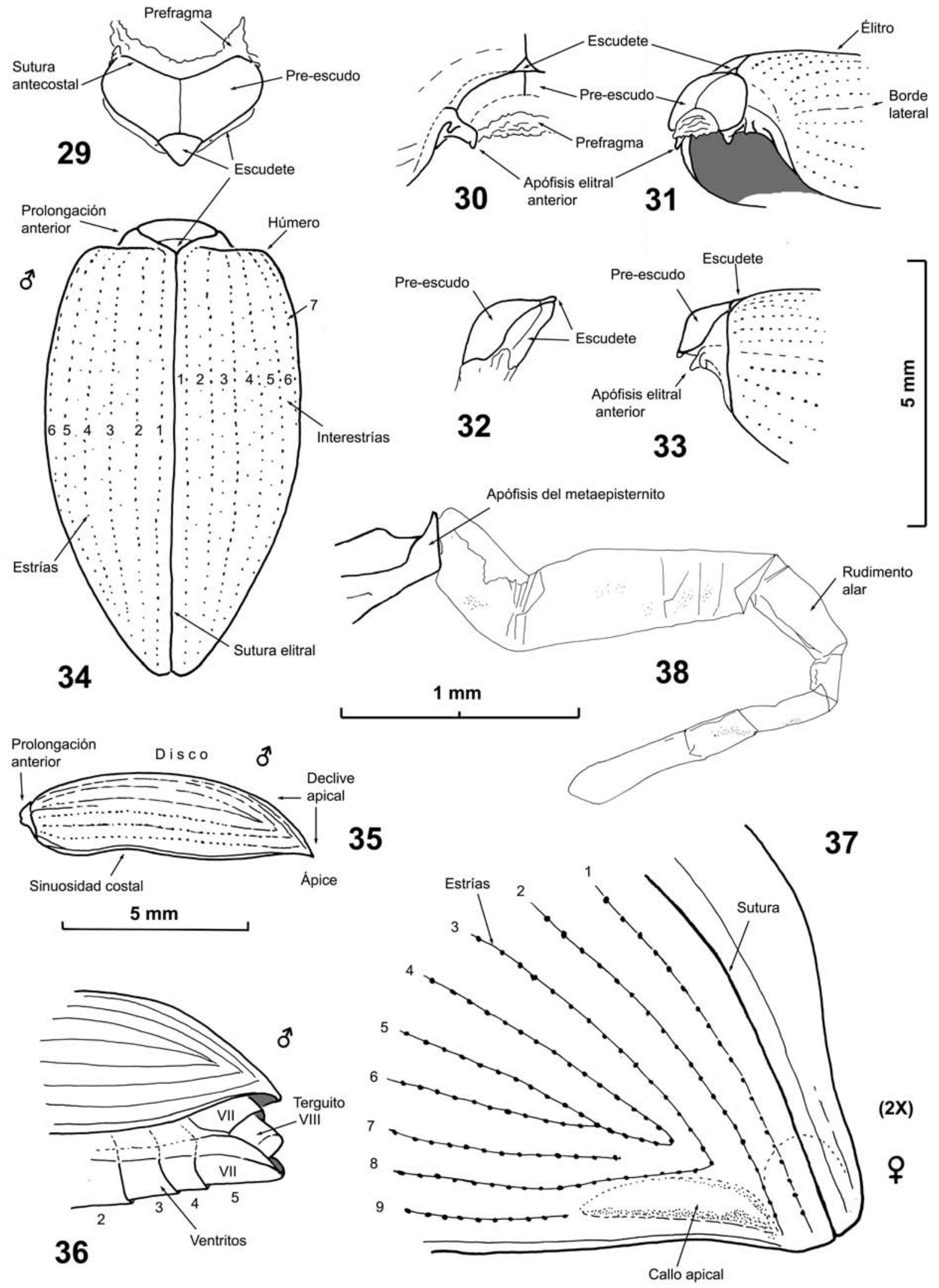

Graellsia, 66(2), Diciembre 2010, pp. 233-280 - ISSN: 0367-5041 doi:10.3989/graellsia.2010.v66.025 
abre en ángulo de $45^{\circ}$ formando dos grandes brazos a modo de alas simples, sin ramificaciones laterales como es común en Entiminae (Morimoto et al., 2006) . Estos brazos furcales poseen una expansión ventral o lámina hacia el margen anterior, que es recto; la lámina posee los bordes recurvados formando una cavidad o vaina (Balfour-Browne, 1961; Velázquez de Castro, 2002); hacia sus extremos se estrechan progresivamente, con las puntas libres (fig. 52). Toda la pieza queda suspendida en la cavidad torácica, anclada lateralmente al pliegue de cada metepisternito mediante un delgado tendón subapical, y por delante, con sendos tendones anteriores, mucho más gruesos, a las bases de los acetábulos mesocoxales y mesendosternitos. Los procesos distales (hemiductus) de las vainas están apenas desarrolladas, y a ellas se agarra la musculatura coxal. El tronco adquiere ventralmente (fig. 52) la forma de quilla longitudinal, y dorsalmente está recorrido por una estrecha carina mediana que no sobresale por delante. En Laparocerus undatus, la relación ancho/largo del metendosternito es de $0,42 x$, y la que existe entre la anchura máxima de los brazos furcales y la de la base es de 2,3x.

\section{Élitros y restos alares}

Los élitros (fig. 34) están engarzados a lo largo de su margen mesal o sutura, aunque no mucho y se pueden desprender con algo de fuerza. En su conjunto, tienen forma oblongo-elíptica subtruncada anteriormente; estilizados en los machos (fig. 35) y en las hembras más anchos, ovales, inflados y con el declive apical más pronunciado (fig. 5); el ápice, visto de perfil, se proyecta ligeramente en pico hacia abajo. Los hombros están desarrollados, el ángulo humeral es obtuso, romo, y existe un callo humeral (tumefacción basal de la $7^{\mathrm{a}}$ interestría), más notorio en las hembras. El disco es poco convexo, el declive lateral pronunciado, y el repliegue ventral muy inclinado hacia dentro y amplio.
En el extremo proximal del élitro se encuentra la apófisis anterior que encaja en el acetábulo definido entre la apófisis preepisternal y el escudo y escudete (figs. 30-33). El margen ventral del élitro presenta una marcada inflexión o sinuosidad a la altura del metasterno (fig. 35). En curculiónidos, las epipleuras se sitúan por dentro y forman parte del mecanismo de fijación del élitro, que consiste en un canal alargado submarginal donde encaja la lámina dorsal del mesepisternito junto a otra hendidura menor y marginal situada cerca de la base y por encima de las mesepímeras (según Morimoto (1962a) no existe reborde costal). A estos enganches se suma otro en el mismo ángulo apical consistente en un breve repliegue y pestaña interna, que encastra un élitro con el otro.

Cada élitro cuenta con diez estrías superficiales finamente punteadas (fig. 34); seis de ellas visibles dorsalmente (la $6^{\text {a }}$ solo en la mitad anterior). Los puntos y la impresión de la estría se hacen más superficiales hacia el ápice, y están menos marcados en las hembras que en los machos. No existe estriola escutelar. Las interestrías, salvo la sutural, que es más estrecha, son amplias y algo convexas al medio, con la superficie un poco irregular debido a abultamientos que son más marcados en las interestrías impares, sobre todo en las externas; el tegumento presenta micro-estriado transversal sobre el que destacan los puntitos algo foveiformes de las pequeñas setas suberectas que hay dispuestas en 12 hileras irregulares.

Existe una ligera depresión postescutelar que afecta a las interestrías 1-2 y otra, subhumeral en la base de la epipleura. La inflexión lateral del borde del élitro (sinuosidad costal, fig.35) se produce a lo largo de la $7^{\mathrm{a}}$ interestría. La $10^{\mathrm{a}}$ estría se desarrolla solo hasta dicha sinuosidad, integrándose la $11^{\mathrm{a}}$ interestría con el reborde elitral a partir de este punto. El anastomosamiento de las estrías en el tercio apical hay que estudiarlo por dentro y al trasluz,

Figs. 39-50'.- Patas. 39) Tibia delantera $\sigma^{7}$. 40) Pata delantera $ᄋ$ (sin coxa). 41) Primer y segundo artejo metatarsal $ᄋ$. 42) Procoxa extraída del cuerpo. 43) Mesocoxa extraídas del cuerpo. 44) Ápice de la protibia O mostrando superficie articular. 45) Ápice de la mesotibia o en visión interior. 46) Ápice de la metatibia o en visión interior. 47) Protarso $\sigma^{7}$ en vista lateral. Protarso $\sigma^{x}$ en vista dorsal. 49) Protarso $\sigma^{x}$ en vista ventrolateral, mostrando almohadillas tarsales. 50) Oniquio en vista ventral. 50') Detalle de la uña en vista lateral.

Figs. 39-50'.- Legs. 39) Fore tibia ㅇ. 40) Hind leg ㅇ (without coxa). 41) First and second metatarsal article ㅇ. . 42) Procoxa separated from body. 43) Mesocoxa separated from body. 44) Apex of protibia + showing articular surface. 45) Apex of mesotibia + , inner view. 46) Apex of metatibia, inner view. 47) Protarsus $\sigma^{7}$ in lateral view. 48) Protarsus $\sigma^{7}$ in dorsal view. 49) Protarsus $\sigma^{7}$ in ventrolateral view, showing tarsal pulvilli. 50) Oniquium in ventral view. 50') Detail of claws. 


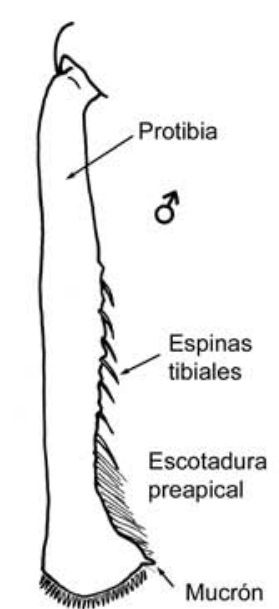

39
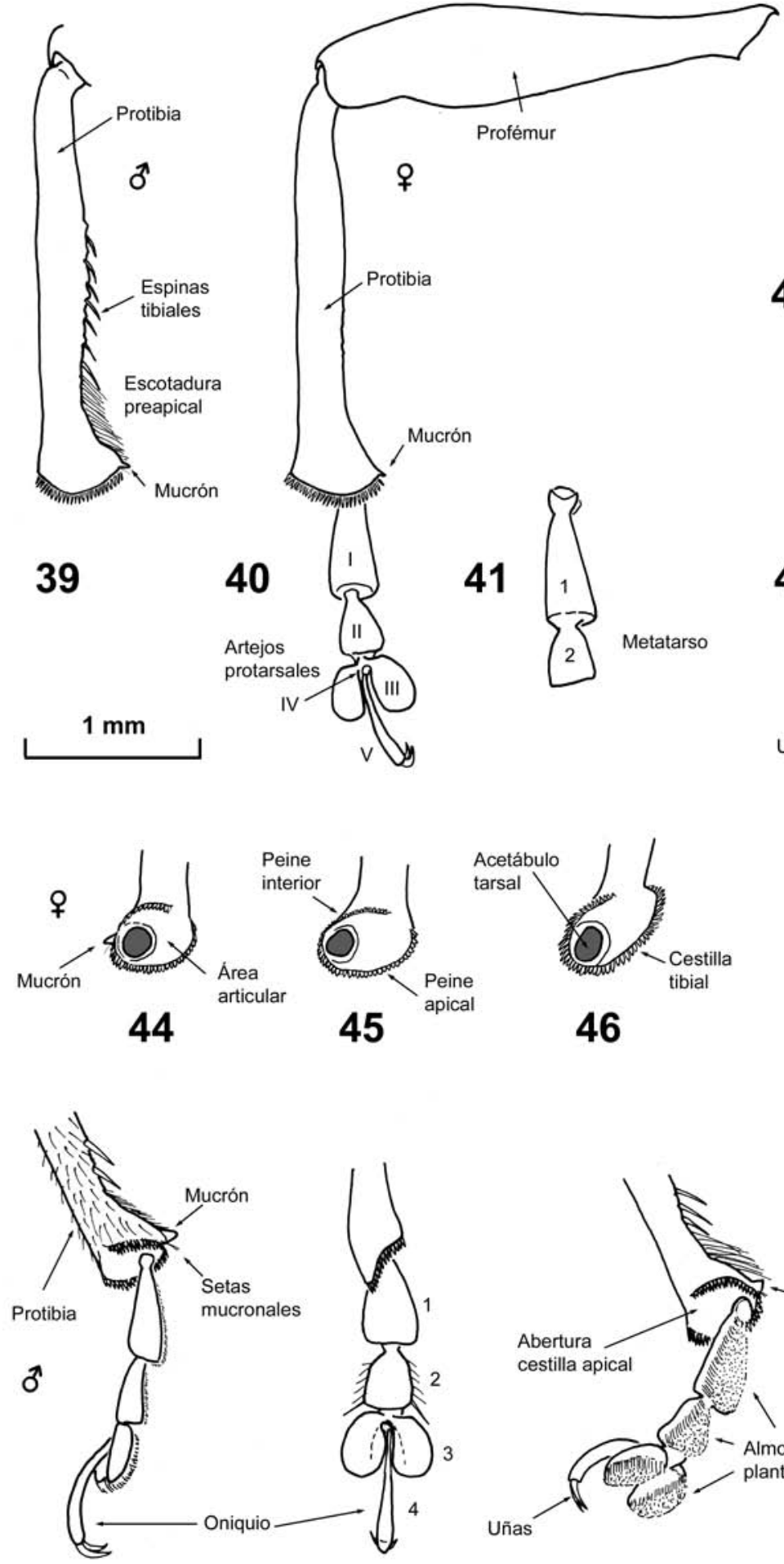

47
48
41
49
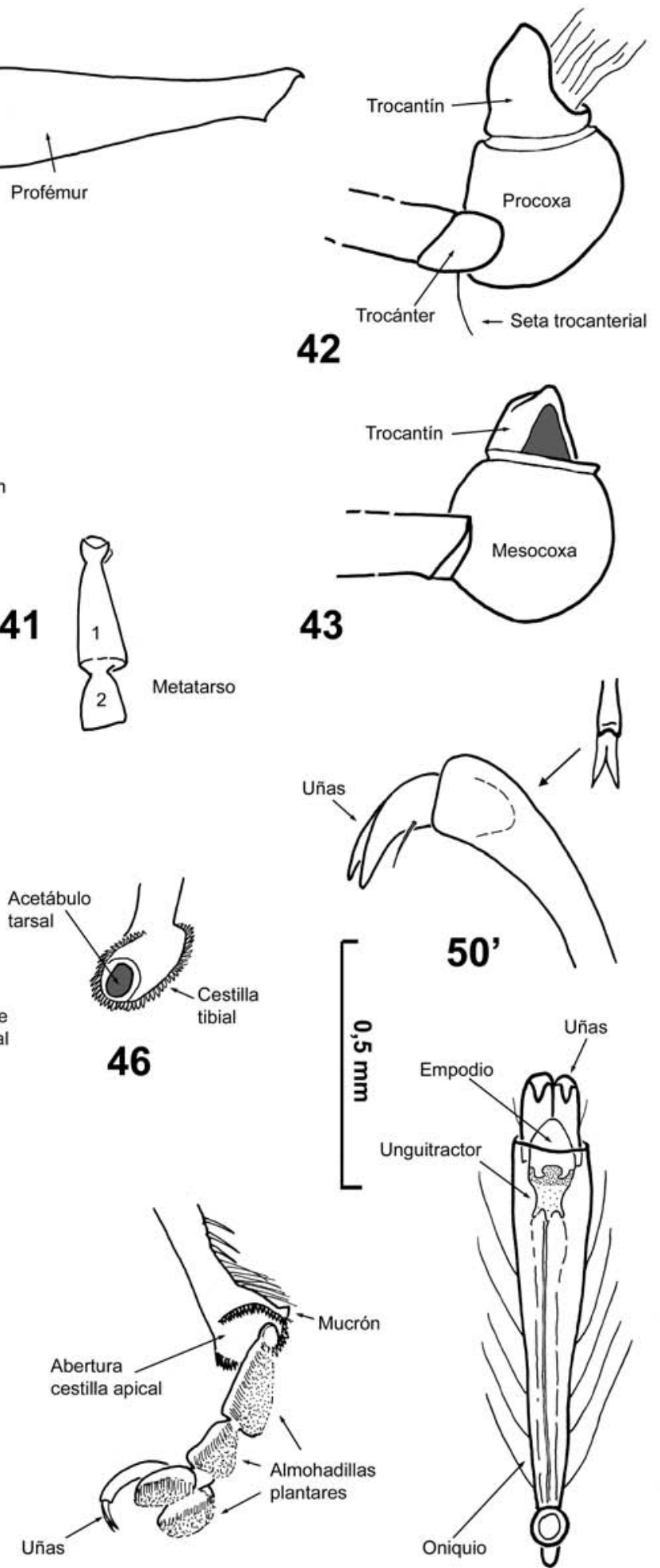

43
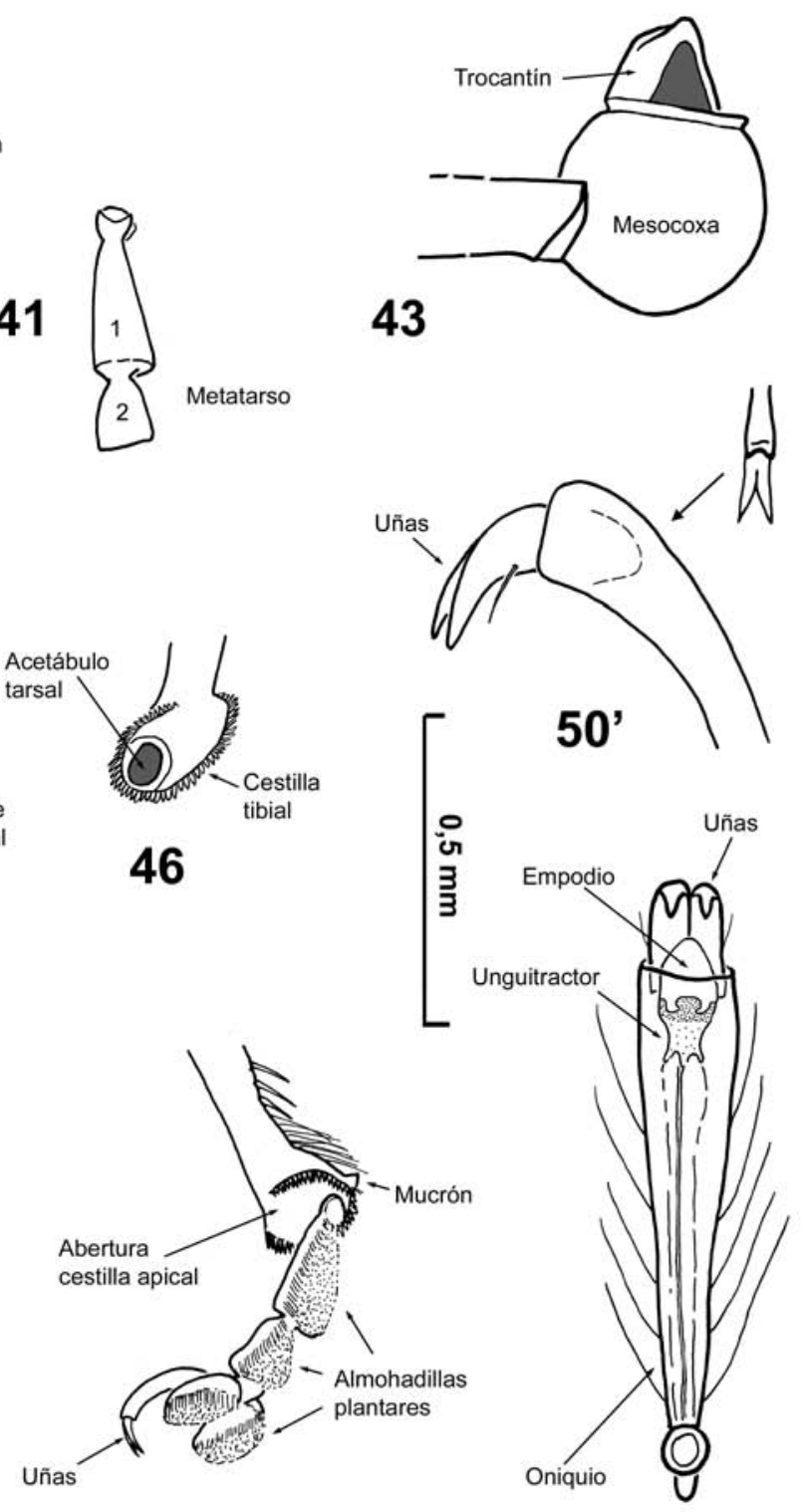

50 
pues no siempre es fácil interpretarlo dorsalmente (estrías borradas). Las estrías $1^{\mathrm{a}}$ y $2^{\mathrm{a}}$ discurren paralelas hasta el ápice, que es plano (a veces, algo deprimido) y truncado posteriormente; la estría $3^{\mathrm{a}}$ se une a la $8^{\mathrm{a}}$, la $5^{\mathrm{a}}$ y $6^{\mathrm{a}}$ se anastomosan entre sí y luego a la $4^{\mathrm{a}}$, quedando libres la $7^{\mathrm{a}}$ y la $9^{\mathrm{a}}$. Ésta última se interrumpe en las hembras ante la presencia de la característica tumefacción de la $9^{a}$ interestría, que se extiende hasta el ápice a nivel de la $2^{\mathrm{a}}$ estría (fig. 37). El abultamiento es bastante llamativo y altera el perfil homogéneo del declive elitral; en los machos no existe este callo anteapical o está apenas insinuado.

Restos alares.- Las alas posteriores del insecto han quedado reducidas a un largo y estrecho tubo acintado y flácido de unos 2-3 mm de longitud, que parte de la apófisis metaepisternal y pende libre en el espacio entre las membranas tergales y los élitros. Se aprecian indicios de división y un marcado estrangulamiento algo esclerosado hacia la mitad, que pudiera representar el punto de pliegue o el pterostigma. Todo su tegumento está provisto de microtriquios, visibles a 200 aumentos. No se distinguen restos de escleritos axilares.

\section{Patas}

Las patas delanteras y medias son aproximadamente de la misma longitud, y las posteriores son algo más largas y están bastante más separadas entre sí (figs. 1-2). Todas las coxas están encajadas en acetábulos en las placas esternales o entre ellas; las procoxas son cónicas y elevadas, las mesocoxas globosas y menos prominentes; ambas están rematadas basalmente por un collarete circular, brevemente emarginado, sobre el que se asienta un trocantín en forma de cono hendido a la mitad, por cuya abertura pasa la musculatura hacia el interior de la pata (fig. 42-43). Las metacoxas son transversales, más anchas, ovaladas y sobresalen muy poco sobre el perfil esternal. Están articuladas lateralmente a través de una pequeña pestaña con la rama basal del furcasterno y con el conjunto metapisternito-metapímero.
Los trocánteres (figs. 26 y 42) son de aspecto triangular, pequeños y todos portan una seta trocanteral fina y larga inserta en un alveolo.

Los fémures (figs. 23 y 40) se insertan oblicuamente sobre los trocánteres, de modo que sus bases quedan muy próximas a las coxas (tipo normal, $s$. Arnett, 1963); son alargados, subcilíndricos y se engrosan moderadamente hacia el ápice (claviformes), con el máximo grosor hacia los tres cuartos, para luego estrangularse preapicalmente (los profémures son más robustos que los demás). El ápice, truncado, está abierto por delante y su margen ventral presenta una gran escotadura en forma de "U" para recibir el cóndilo de la tibia. Todos los fémures son inermes y cuentan tan solo con una vestimenta rala de escamitas lanceoladas adpresas.

Las tibias son rectas en esta especie (figs. 3940), algo comprimidas, y se articulan a través de un cóndilo globular excéntrico, quedando su movilidad parcialmente limitada por las paredes del acetábulo femoral. La truncadura apical es oblicua dorso-ventral y lateralmente, dejando al área articular expuesta hacia atrás, con el consiguiente ensanchamiento del ápice tibial a modo de abanico, algo más pronunciado hacia dentro en los machos (fig 39). El área articular es oval, mayor en la mesotibia (fig. 45) y más aún en la metatibia, donde su eje, respecto del principal de la tibia, pasa de ser perpendicular a oblicuo (fig. 46). La superficie es lisa, sin carina interna ni espuelas tibiales, y el acetábulo tarsal se abre en su ángulo interno, tangente al borde. La llamada cestilla (“corbels" s. Torre Bueno, 1989) la forman una empalizada de setas recias aplastadas -a menudo muy desgastadas- que orla el borde distal (peine apical) y otra contigua que recorre el borde proximal (peine interior), interrumpida en su extremo proximal-externo para dejar espacio a los tarsos, de modo que puedan replegarse contra la tibia. Esta condición de "cestilla abierta" es generalizada en Laparocerus.

En los machos, existe un modesto mucrón próximo o tangente al ángulo interno, pero no apical

Figs. 51-58.- Endosqueleto del pterotórax y abdomen. 51) Estructura interna del meso- y metatórax mostrando endosque-

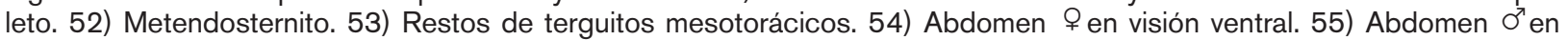
visión ventral. 56) Espiráculo torácico. 57) Espiráculos abdominales. 58) Abdomen + en visión lateral (élitros retirados).

Figs. 51-58.- Internal stucture of pterothorax and abdomen. 51) Internal structure of meso- and methatorax. 52) Metendosternite. 53) Remants of mesothoracic tergites. 54) Abdomen $O$ in ventral view. 55) Abdomen $O^{7}$ in ventral view. 56) Thoracic spiracle. 57) Abdominal spiracles. 58) Abdomen $O$ in lateral view (elytra removed). 


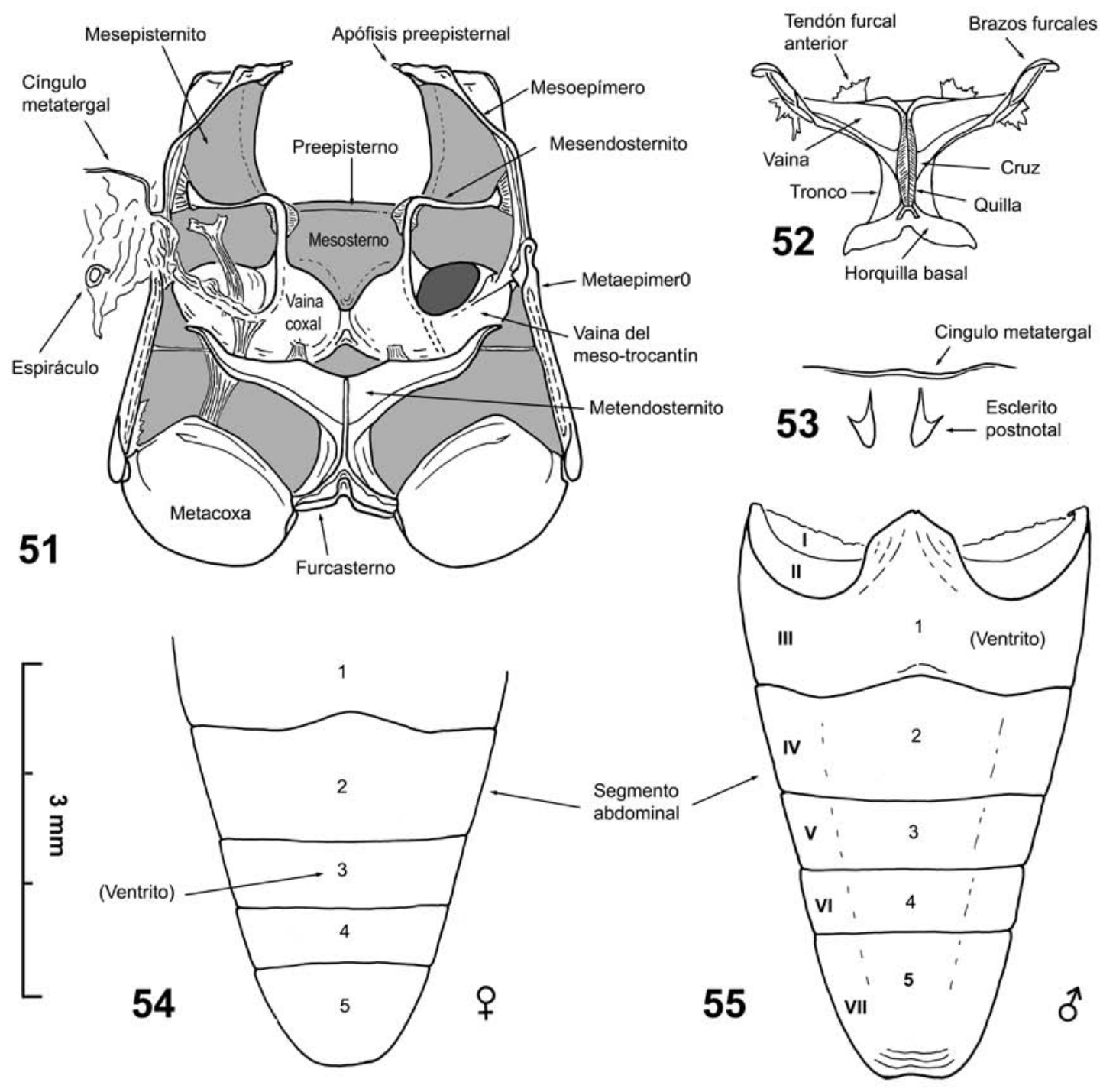

56

[ Espiráculos

57<smiles>c1ccccc1</smiles>

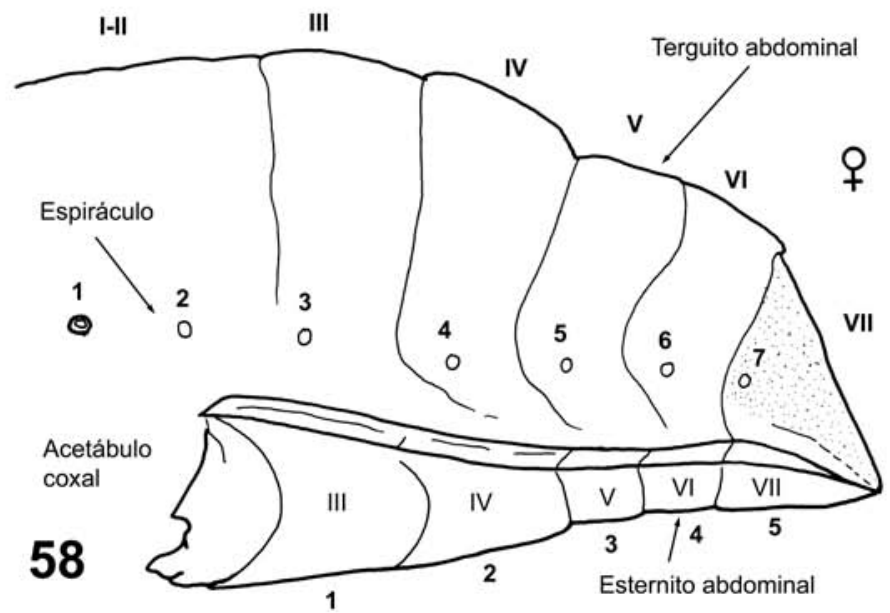


(pre-mucrón, según el criterio de Kuschel, 1951), con dos setas mucronales finas que sobresalen sobre las demás; está bien desarrollado en las protibias y menos en las meso y metatibias; en las hembras solo existe un mucrón pequeño en la protibia.

Las protibias masculinas muestran una amplia escotadura o estrangulamiento interno en su mitad distal (figs. 2 y 39), cuyo borde dispone de pequeños dentículos (incipientes en las hembras). Sobre este margen se implantan unas cuantas espinas tibiales que destacan entre las escamitas flavas setiformes o lanceoladas que visten la tibia, y que aumentan en longitud y densidad hacia el ápice. Las metatibias muestran también 4-5 pequeños dentículos a lo largo de su canto interno. La cara ventral de las pro- y mesotibias, está algo excavada en su tercio apical y la recorre un canal medio liso, que, en muchos Laparocerus, es rematado distalmente por un conjunto denso de pelos cortos a modo de "almohadilla tibial". Precisamente, en $L$. undatus está muy poco desarrollada.

Las tibias subcilíndricas o deprimidas provistas de mucrón son comunes en curculiónidos que trepan a la vegetación. Por la estructura de su región articular apical, las de Laparocerus encajarían en el tipo Noterini, según Morimoto (1962a).

El tarso (figs. 40, 47-49) está formado por 5 artejos o tarsómeros, aunque aparentemente sólo 4 son visibles. El artejo I se articula mediante un cóndilo globoso en el acetábulo de la tibia, con gran libertad de movimiento. Los artejos II y III se articulan del mismo modo sobre el precedente. El III es bilobulado; el IV es muy pequeño y está encastrado entre los lóbulos del III y soldado a la base del V, formando el oniquio ( $4^{\circ}$ visible aparentemente) (fig. 50). Éste es largo, arqueado y delgado, particularmente hacia su base, acoplada al $4^{\circ}$; apicalmente porta un par de cortas uñas unidas por la base, lo que se designa como "uñas soldadas" o "rígidas" (s. Morimoto, 1962). En la cara externa de las uñas existe una diminuta seta, como es típico en Entiminae (fig. 50'). El primer tarsómero es algo más largo que los dos siguientes (sobre todo en el metatarso, fig. 41) y los tres están cubiertos ventralmente de pulvilli, o pelos cortos apretados, formando las almohadillas plantares (fig. 49), que otorgan adhesión y ayudan al insecto a trepar. El oniquio sobresale de los lóbulos del tercer artejo y los duplica prácticamente en longitud; el empodio es lampiño.

\section{ABDOMEN}

Se acepta que el abdomen de los curculiónidos está constituido por diez u once segmentos, aunque solo cinco - del III al VII- son visibles en la cara ventral, por lo que es práctico designarlos con números romanos y emplear los arábigos 1-5 para referirlos topológicamente como ventritos (figs. 3 y 55). Los esternitos I y II se encuentran reducidos y solo son visibles en la pared interna de la cavidad coxal (fig. 55), mientras que los VIII-X se han invaginado o forman parte de las estructuras genitales.

Los ventritos 1-2 están parcialmente soldados y la línea de unión entre ellos es bastante arqueada hacia delante -procurva- en su tramo medio. Los demás se acoplan libremente con membranas interconectivas, incluidos sus pliegues laterales, lo que otorga cierta flexibilidad al conjunto a fin de poder abatir el extremo abdominal durante la cópula, la puesta o la defecación. El $2^{\circ}$ ventrito es tan largo a la mitad como el $3^{\circ}$ y $4^{\circ}$ reunidos, y el $5^{\circ}$ es algo más largo que estos dos reunidos y termina truncado o ligeramente escotado en el macho (fig. 55), mientras que en la hembra es más corto y termina en arco (fig. 54), diferencia sexual que suele ser normal en los Laparocerus.

El esternito VIII masculino es completamente membranáceo, salvo por una breve pieza impar en forma de $\mathrm{T}$, ahorquillada en la base y anclada en la mediana, que puede interpretarse como un spiculum relictum ( $s$. Thomson, 1992). Esta pieza parece ser una característica común a todos los Laparocerus.

En el dorso, al retirar los élitros, quedan expuestos teóricamente los tergos de $8\left(\sigma^{7}\right)$ o 7 ( 우) segmentos (fig. 56), cuyo reconocimiento no es fácil. Los seis primeros son membranáceos y carecen de terguitos y de pleuritos laterales o espiraculares, acorde con el abdomen de tipo "normal" $s$. Morimoto (1962a), propio de especies ápteras. Las separaciones entre el tergo metatorácico y el primero abdominal, y entre éste y el segundo, apenas se distinguen, aunque lateralmente existen dos espiráculos; el anterior es el espiráculo metatorácico (fig. 56 ), visiblemente mayor, y el siguiente debe pertenecer al segmento I o II, y es menor que el metatorácico e igual en tamaño a los cinco restantes (figs. 57-58). A partir del espiráculo III la separación de los terguitos está bien definida y concuerda con los esternitos subyacentes. El terquito VII está esclerosado, porta setas en su margen y el espiráculo se emplaza en el ángulo antero-lateral, sobre la parte esclerosada. En la hembra, el VIII terguito está 
cubierto por el VII. En el macho el VIII terguito queda parcialmente expuesto (pigidio) y los márgenes están reflejados para hacer de estuche; en la base, al medio, el esclerosamiento es menor y se distinguen los dos hemiterguitos que lo originaron; en sus ángulos basales cuenta con sendas apófisis bien desarrolladas que reciben la musculatura (fig. 69).

\section{Morfología interna del adulto}

\section{CANAL ALIMENTARIO}

El canal alimentario comprende tres partes: anterior, media y posterior (fig. 60). La proporción del tramo anterior respecto del total es del $18 \%$, moderadamente larga, siendo lo normal $8-15 \%$ en entiminos con cabeza no particularmente estirada (Calder, 1898); el tramo medio representa el 34\%. En su extremo anterior se encuentra la hipofaringe con apertura de contorno oval algo esclerosada que abre directamente en el esófago (fig. 61).

El esófago se conecta distalmente con el proventrículo, presentando un ligero ensanchamiento previo que podría ser interpretado como un buche incipiente (Aslam, 1961). El proventrículo (figs. 62-63) está bien desarrollado y tiene forma de farolillo octogonal, con ocho costillas longitudinales y ocho láminas provistas de doble hilera de setas aplastadas unidas por delante, que conforman la zona filtradora (fig. 64); apical e interiormente se dispone un corto fleco de sedas de cierre a contrapelo (fig. 65); la zona de placa es muy corta y carece de dientes. Esta configuración coincide con el tipo VI de Calder (1989), el más común en curculiónidos, y dentro de él se aproxima al subtipo b, al quedar un espacio libre antes del borde de la lámina. En los Entiminae la zona de placa suele estar bien diferenciada y contar con dientes (tipo VIe). El interior del esófago carece de cilios o dentículos.

Tramo medio: El proventrículo se abre a través de un collarín en el ventrículo anterior, que es largo, dilatado y lobulado en la base (hembra), estrechándose progresivamente hacia atrás (fig. 60) para conectar oblicuamente con el ventrículo posterior, conformado por un tramo tubular recurvado, semirígido y de diámetro uniforme, que en su mitad distal -tras un breve estrangulamiento- porta dos hiladas laterales de abundantes ciegos entéricos (caeca) o papilas tipo 2, en el sentido de Calder (1989), presuntamente contenedores de organismos simbiontes.
El tramo posterior es más retorcido, y consiste en tres partes: el íleon, el colon y el recto (fig. 60). El ileon es la porción más larga, flexible y delgada, que se dobla en "u" sobre sí mismo en su extremo posterior, como es característico en Rhynchophora (Aslam, 1961). Los tubos de Malpighi (criptonefridios) son seis en número, cuatro extremadamente largos y dos más cortos. Se disponen revueltos en la cavidad abdominal y parten de los flancos laterales agrupados a pares $(2+4)$ en el extremo anterior del ileon y acaban en los flancos de su extremo distal (3 +3 ), algo adelantados. Esta configuración la define Calder (1989) como tipo III. Sigue el colon, que es un tubo más grueso y rígido, liso y de diámetro uniforme. Su unión con el recto está bien delimitada por una constricción o válvula rectal transversal, no oblicua. El recto es más estrecho y mitad de largo, disminuyendo en grosor progresivamente hasta el ano, situado sobre la abertura genital al final del segmento IX, protegido por el terguito VIII (fig. 77).

\section{SISTEMA NERVIOSO CENTRAL}

El sistema nervioso central consiste en un frágil cordón con varios ganglios, doble en su tramo cefálico y torácico, y simple en el tramo abdominal (fig. 59). El ganglio cerebroide (cerebro) es grande y se distinguen bien los lóbulos oftámicos laterales; el arco periesofágico lo enlaza con un ganglio subesofágico alargado, desprovisto de ramificaciones; éste se conecta al ganglio protorácico, corto, con una rama lateral a cada lado, y continúa con dos conectores hasta el conjunto del ganglio meso y metatorácico, que están fusionados (se distinguen bien), portadores, cada uno, de una rama gruesa y otra estrecha, a cada lado. A partir de aquí, sigue un cordón impar a lo largo del que se anudan los ganglios abdominales, ovales, alargados e indiferenciados, al menos en número de dos, y posiblemente tres (estado primitivo, según Aslam, 1961).

\section{APARATO REPRODUCTOR MASCULINO}

Como es común en los coleópteros, el aparato reproductor masculino está compuesto por una parte de origen mesodérmico donde se genera el esperma (gónadas o genitalia interna), y otra ectodérmica, que comprende el aparato copulador, incluido el conducto eyaculador, y algunos escleritos auxiliares. 


\section{Gónadas}

Los testículos son muy grandes $(4-5 \mathrm{~mm}) \mathrm{y}$ están formados cada uno por dos amplios lóbulos planos y contiguos dispuestos a lo largo del cuerpo, compartiendo una misma envoltura (fig. 66). El lóbulo anterior es algo mayor y rectangular, con una veintena de folículos, y el posterior, cuyo extremo es triangular, cuenta con una quincena. Los dos vasos eferentes (vasa efferentia), adosados a los lóbulos, están muy engrosados, a modo de vejiga y desembocan juntos en el extremo distal del conducto deferente (vas deferens), que en este tramo presenta un engrosamiento homólogo (supuestamente para almacenar esperma), para luego continuar como conducto delgado y unirse a una de las cortas ramas del conducto eyaculador. En este punto de unión existe una corta expansión de tejido bajo la que convergen una docena compacta de túbulos arrosariados (algunos divaricados). Calder (1990) emplea el término de "racimo de uvas" para referir al amasijo equivalente observado en Cleonini y algún Amycterinae. Poco antes de esta unión y dorsalmente se insertan anastomosadas dos glándulas accesorias con forma de tubo delgado, largo y contorneado; una es muy larga y la otra apenas un cuarto de su longitud. La unión de todas estas piezas queda oculta por el amasijo de la glándula seminal.

\section{Órgano copulador}

Consta de tres piezas: conducto eyaculador, edeago y espículo gastral.

Conducto eyaculador.- El vaso deferente de cada testículo se prolonga en un breve conducto eyaculador que se unen para formar un único conducto, paralelo al edeago, más grueso y bastante rígido (musculado) en este primer tramo (fig. 66); luego tuerce $180^{\circ}$ y a modo de tubito delgado y flexible recorre en sentido inverso el edeago hasta desembocar en su saco interno (fig. 75), punto que constituye el gonoporo. Justo antes de esta unión el conducto está rodeado por un envoltorio muscular.
Edeago.- El edeago (aedeagus) está formado por el tegmen, con sus membranas anterior y posterior y por una pieza tubular esclerosada y retráctil que se desliza por dentro de él, el lóbulo medio (penis, phallus), con sus temones (figs. 72-74).

La pieza basal del tegmen (fig. 71) tiene forma anular y rodea el lóbulo medio permitiendo su deslizamiento hacia atrás y hacia delante (tipo anular $s$. Lindroth \& Pálmen, 1973). Ventralmente se prolonga en una apófisis impar alargada y rígida, el manubrio, dirigido hacia delante; dorsalmente, porta dos lóbulos parameroides o parámeros delgados y translúcidos, con flecos microscópicos en sus puntas. Sobre la pieza basal del tegmen y hacia atrás se inserta la primera membrana conectiva (membrana tegminal posterior, s. Sharp, 1918; post-tegminal, s. Wanat 2007), que a modo de tubo se proyecta hasta conectar con el extremo posterior laminado del espículo y la membrana esternal IX, dejando libre la abertura genital. La segunda membrana conectiva (membrana pre-tegminal) se prolonga un poco más allá de la pieza basal, para replegarse hacia dentro (en estado de reposo) y continuar hasta unirse al lóbulo medio.

El lóbulo medio es un tubo largo, aplastado, membranáceo en su parte dorsal y esclerosado lateral y ventralmente (pedon), salvo por una incursión basal, la abertura ventral, que alcanza casi un tercio de su longitud (fig. 72). Esta conformación sin tectum esclerosado es característica de los Curculionidae y Alonso-Zarazaga (2007) la designa como "pedal"(genitalia gonatocera ex aucct.). En vista dorsal, el lóbulo medio se estrecha progresivamente hacia atrás para terminar el ápice en punta afilada y recta (forma de piragua), donde se abre el orificio apical (ostium penis) subapicalmente. Visto de perfil, el lóbulo medio es bastante rectilíneo salvo en su parte basal, que está ligeramente arqueada y a cuyo extremo se unen, en ángulo muy abierto y poco marcado, un par de temones bastante rectilíneos, poco engrosados anteriormente y un tercio más cortos que la longitud del lóbulo medio. El edeago, en su conjunto, abarca todo el largo de la cavidad abdominal.

Figs. 59-65.- Sistema nervioso y canal alimentario. 59) Sistema nervioso central. 60) Canal alimentario. 61) Hipofaringe. 62) Proventrículo en vista anterior. 63) Proventrículo en vista lateral. 64) Lámina proventricular en vista externa. 65) Ápice de una lámina proventricular vista por dentro.

Figs. 59-65.- Nervous system and alimentary canal. 59) Central nervous system. 60) Alimentary canal. 61) Hypopharynx. 62) Proventriculus in anterior view. 63) Proventriculus in lateral view. 64) Proventricular blade, view from outside. 65) Apex of proventricular blade, view from inside. 


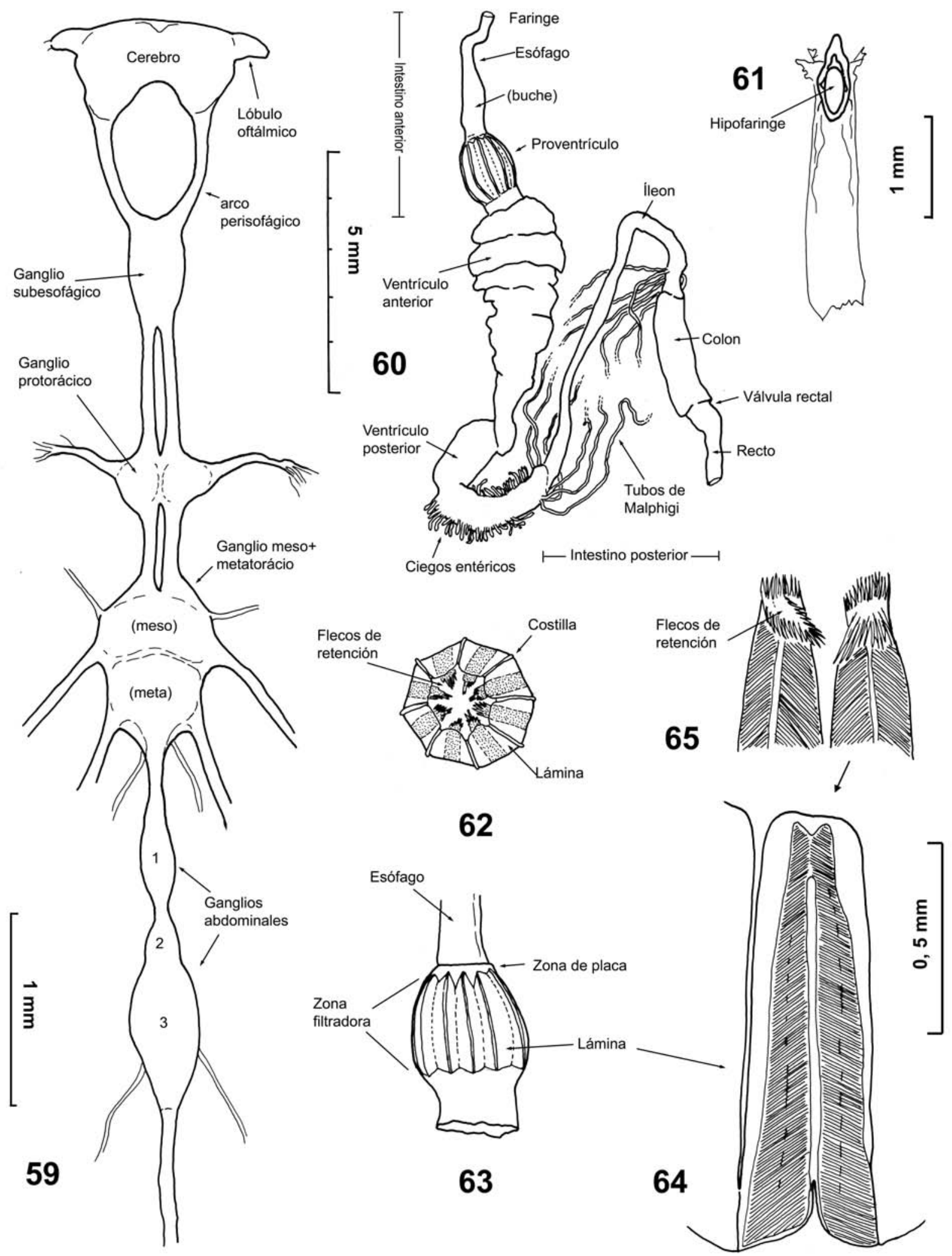


Dentro y a lo largo del lóbulo medio se encuentra el saco interno eversible (endophallus), que es de tipo tubular (s. Arzanov, 2003). Se trata de un largo tubo membranáceo transparente que se une a las paredes internas del lóbulo medio alrededor de su abertura apical (ostium penis), orificio por el que, durante la cópula, se proyecta hacia afuera -evaginándose- para penetrar la vagina y exponer el gonoporo, permitiendo la transfusión de esperma.

En reposo, el saco interno sobresale por la base del lóbulo medio y queda entre los temones, a los que, en esta especie, rebasa en trecho equivalente a la longitud de estos últimos, por lo que suele plegarse sobre sí mismo (fig. 74). En su misma base, junto al margen prepucial (s. Arzanov, 2003) existe un par de pequeños apéndices digitiformes con el ápice recurvado hacia abajo y atrás, que normalmente reposan en el interior acanalado de la punta del lóbulo medio por delante de la abertura apical, y asoman colgando uno a cada lado cuando el saco interno se extiende; se desconoce su función y podrían designarse como apéndices prepuciales o "bigoteras" (fig. 75).

El conducto eyaculador se conecta sobre un pequeño divertículo digitiforme, el divertículo gonoporal, que se inserta ventro-lateralmente a mitad del tubo general. Éste queda así dividido en un largo divertículo ciego distal, y en un tubo basal común a ambos divertículos. El tegumento del divertículo gonoporal está densamente cubierto de escámulas, y envuelve al conducto eyaculador en su inserción en un tramo difícil de precisar, pero sin esclerificaciones notables que puedan interpretarse como un flagelo (a lo sumo, incipiente); tampoco existe aparato trasponedor. El divertículo ciego es ligeramente bífido en su extremo distal, y hacia la base presenta dos pequeños campos de dientes esclerosados asimétricos. El tubo común muestra un campo de dientes doble mucho más desarrollado, próximo a donde se inserta los divertículos (tramo medio), mientras que en su tramo basal el tegumento muestra un estríado oblicuo y lleva adosado en el lado derecho una delgado pieza arqueada y de cabeza bífida, que debe facilitar de algún modo la eversión y posterior recuperación del saco; podría tratarse de los frena fusionados o de un "esclerito ostiolar" (s. Arzanov, 2003). El tegumento que constituye el saco está tapizado en gran parte (un lateral del tramo medio) por escámulas o dentículos microscópicos más o menos desarrollados, mucho menores que los dientes fuertemente esclerosados, cuyos campos varían en posición y desarrollo según la especie y son muy útiles en la sistemática del grupo. En la figura $75 \mathrm{el}$ saco se ha extraído directamente del lóbulo medio para representarlo, pero no se ha revertido ni está hinchado como ocurre durante la cópula, momento en que el conducto seminal discurre por dentro y los dientes quedan expuestos hacia afuera y sirven de enganche específico. Para observar bien la armadura del saco y su configuración tridimensional hay que evaginarlo, pero se trata de una operación difícil, incluso en animales grandes.

Durante la cópula, el lóbulo medio es proyectado hacia delante y todas estas piezas y membranas, incluido el saco interno, quedan alineadas para formar un larguísimo tubo compuesto, que termina en el gonoporo. El lóbulo medio se queda en la cloaca y no penetra la hembra, por lo que el nombre de pene (penis) que emplean algunos autores tal vez no sea el más apropiado.

Espículo gastral.- El espículo gastral (spiculum gastrale) es la pieza auxiliar rectilínea muy robusta que mantiene al edeago en posición y hace de guía durante su proyección (figs. 68-70). Según Morimoto (1962) corresponde al esternito IX. Thompson (op. cit.) afina más y considera al spiculum gastrale como el apodema del esternito IX, que comprendería además las expansiones laterales laminares de su extremo posterior. Éste está escotado en "V" en $L$. undatus, y las expansiones son cortas y se unen a la membrana esternal IX-X y a la primera conectiva del

Figs. 66-75.- Aparato reproductor masculino. 66) Gónadas masculinas. 67) Ápice abdominal $\sigma^{7}$ en vista lateral con los esternitos retirados. 68) Espículo relicto. 69) Terguito abdominal VIII (pigidio) en vista dorsal. 70) Espículo gastral. 71) Tegmen. 72) Edeago en vista lateral. 73) Edeago en vista dorsal. 74) Edeago en vista ventral. 75) Punta del lóbulo medio con el saco interno extraído (no evertido).

Figs. 66-75.- Male reproductive system. 66) Male genitals. 67) Abdominal apex in lateral view (sternites removed). 68) Spiculum relictum. 69) Abdominal tergite VIII (pigydium) in dorsal view. 70) Spiculum gastrale. 71) Tegmen. 72) Edeagus in lateral view. 73) Edeagus in dorsal view. 74) Edeagus in ventral view. 75) Apex of median lobe with extracted internal sac (not everted). 


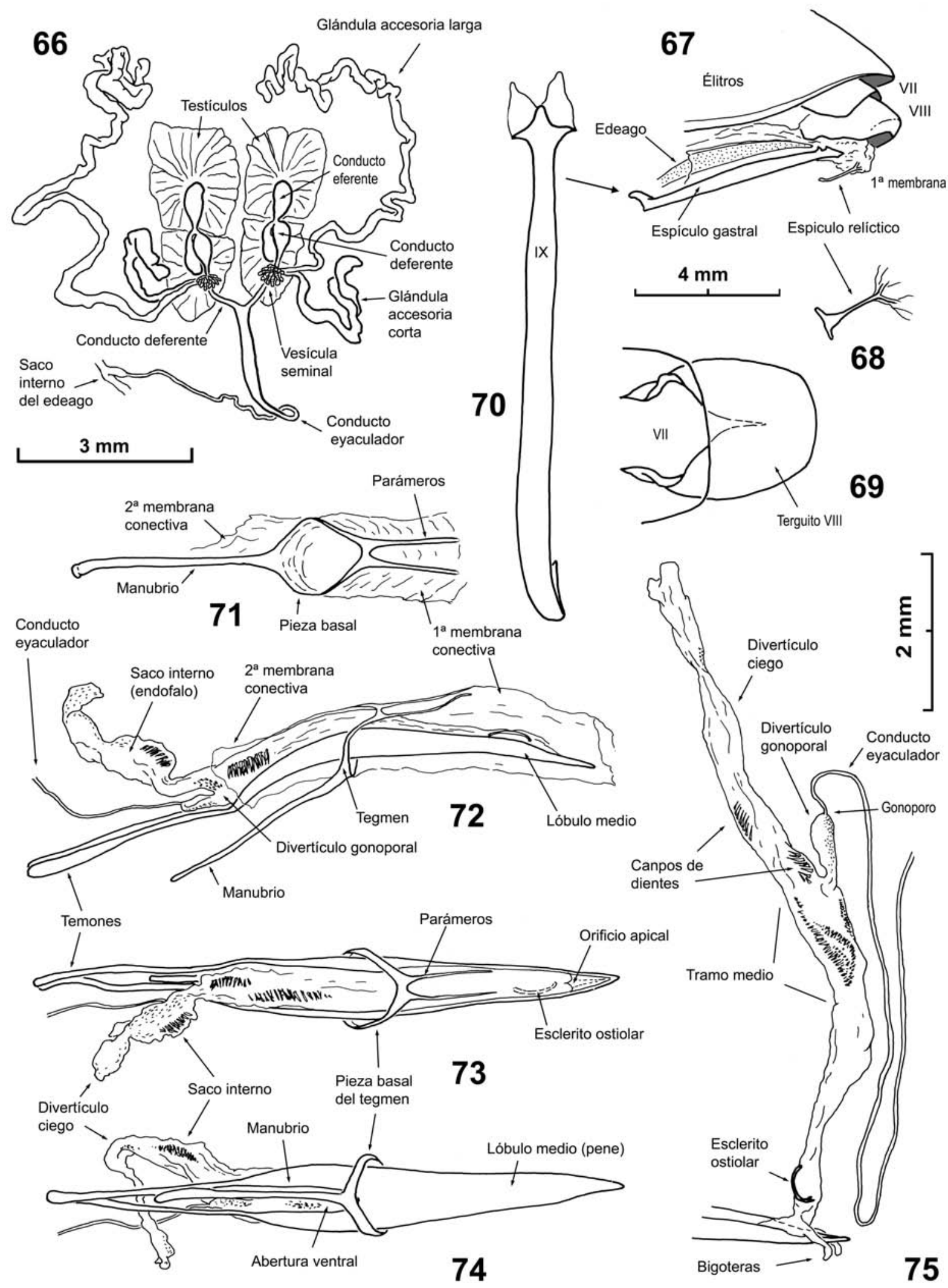


tegmen. Su extremo anterior es recurvado para abrazar por el lado derecho el extremo anterior del edeago (parámeros y saco interno) cuando está en reposo, a la vez que sirve de anclaje al poderoso paquete muscular que envuelve esta región del edeago y que también se agarra al manubrio.

\section{APARATO REPRODUCTOR FEMENINO}

Análogamente al aparato reproductor masculino, el femenino consta de unas gónadas de origen mesodérmico (ovarios y oviductos laterales) y otra parte ectodérmica, la genitalia (oviducto común, bolsa copulatriz, espermateca, vagina y ovipositor), además del esternito VIII, que presenta una lámina y cuyo apodema es el espículo ventral.

\section{Parte mesodérmica}

Los ovarios son dos, situados en posición dorsolateral en el abdomen, y varían mucho en función de su estado de madurez, ocupando un enorme espacio en la cavidad abdominal cuando contienen huevos desarrollados.

En su estado inicial, cada ovario está formado por dos ovariolos acrotróficos alargados (fig. 80), cuyo germario (germarium) se distingue bien del vitelario (vitellarium), en la base, mucho más delgado en esta fase inactiva. Los dos ovariolos desembocan en un mismo conducto, el oviducto lateral, que luego se une al del otro ovario para confluir en el oviducto medio. En el extremo anterior, los filamentos terminales de cada ovariolo se unen apicalmente para anclarse conjuntamente a la pared del tubo digestivo. El desarrollo progresivo de los oocitos puede distinguirse en el vitelario en fases de maduración más avanzadas (fig. 81). En Laparocerus, los ovarios no siempre maduran simultáneamente.

\section{Parte ectodérmica}

La genitalia femenina se sitúa ventralmente, por debajo del canal alimentario, y es bastante compleja, como suele ocurrir en curculiónidos provistos de un ovipositor tipo tubular ( $s$. Lindroth \& Palmén, 1970).
Oviducto común.- Los oviductos laterales de los ovarios (endodérmicos) conectan con el oviducto medio o común, permitiendo el acceso de los huevos a la vagina.

Vagina.- La vagina es muy grande, tubular, amplia, aplastada y en forma de " $Z$ " alargada y bastante rígida (fig. 79). Se conecta en su extremo anterior con la bolsa copulatriz y en el posterior con el ovipositor. En su tramo medio posterior se ensancha un poco y presenta ventralmente una invaginación cavernosa, en cuyo fondo desembocan el oviducto común y el conducto espermatecal, punto donde son fecundados los huevos. En su interior y sobre las paredes del anillado muscular se aprecian varias microesclerificaciones, en disposición irregular.

Espermateca.- La espermateca (fig. 82) es pequeña y falciforme (recuerda a una pajarita de papel). El cuerpo principal es globoso y continuo con la cola, que es recurvada; en el otro extremo se encuentra el lóbulo del conducto espermatecal (nodulus ex auct.), y el otro lóbulo, al medio y en posición dorsal, es el lóbulo glandular (ramus ex auct.) del que parte una larguísima glándula accesoria filiforme (fig. 79), la glándula de la espermateca. El ducto espermatecal es igualmente muy largo, flexible y nada esclerificado. Se ha adoptado la terminología propuesta por Thompson (1989) y apoyada por Kuschel (1989).

Bolsa copulatriz.- La bolsa copulatriz (bursa copulatrix) es muy grande y se abre en el extremo anterior de la vagina y bastante lejos del gonoporo/oviporo. Posee un largo pedicelo, y cuando está henchida forma una gran pelota en el interior de la cavidad abdominal. Eliminado el tejido graso, se pueden distinguir dos túbulos delgados (¿signa?) que rodean el amasijo semiesférico que resta en el interior (fig. 79).

Ovipositor-- El ovipositor es una estructura tubular que en reposo se retrae sobre sí misma y es casi tan larga como la vagina (fig. 78). Para la puesta se proyecta telescópicamente hacia afuera, adquiriendo una longitud considerable. La parte basal lisa o pretubo, se distingue bien de la apical, más corta y bien esclerosada, conformada por dos hemisternitos (fig. 76) que representan el IX esternito (Lindroth \& Pal-

Figs. 76-83.- Aparato reproductor femenino. 76) Hemisternitos del ovipositor. 77) Disposición de los segmentos apicales en el abdomen Q. 78) Espículo ventral. 79) Aparato genital femenino en visión ventral (faltan los ovarios). 80) Ovario izquierdo. 81) Ovario en desarrollo. 82) Espermateca. 83) Huevo.

Figs. 76-83.- Female reproductive system. 76) Hemisternites of oviscapt. 77) Disposition of apical abdominal segments ( ). 78) Spiculum ventrale. 79) Female genital system in ventral view (ovaries missing). 80) Left ovary. 81) Developing ovariole. 82) Spermatheca. 83) Egg. 


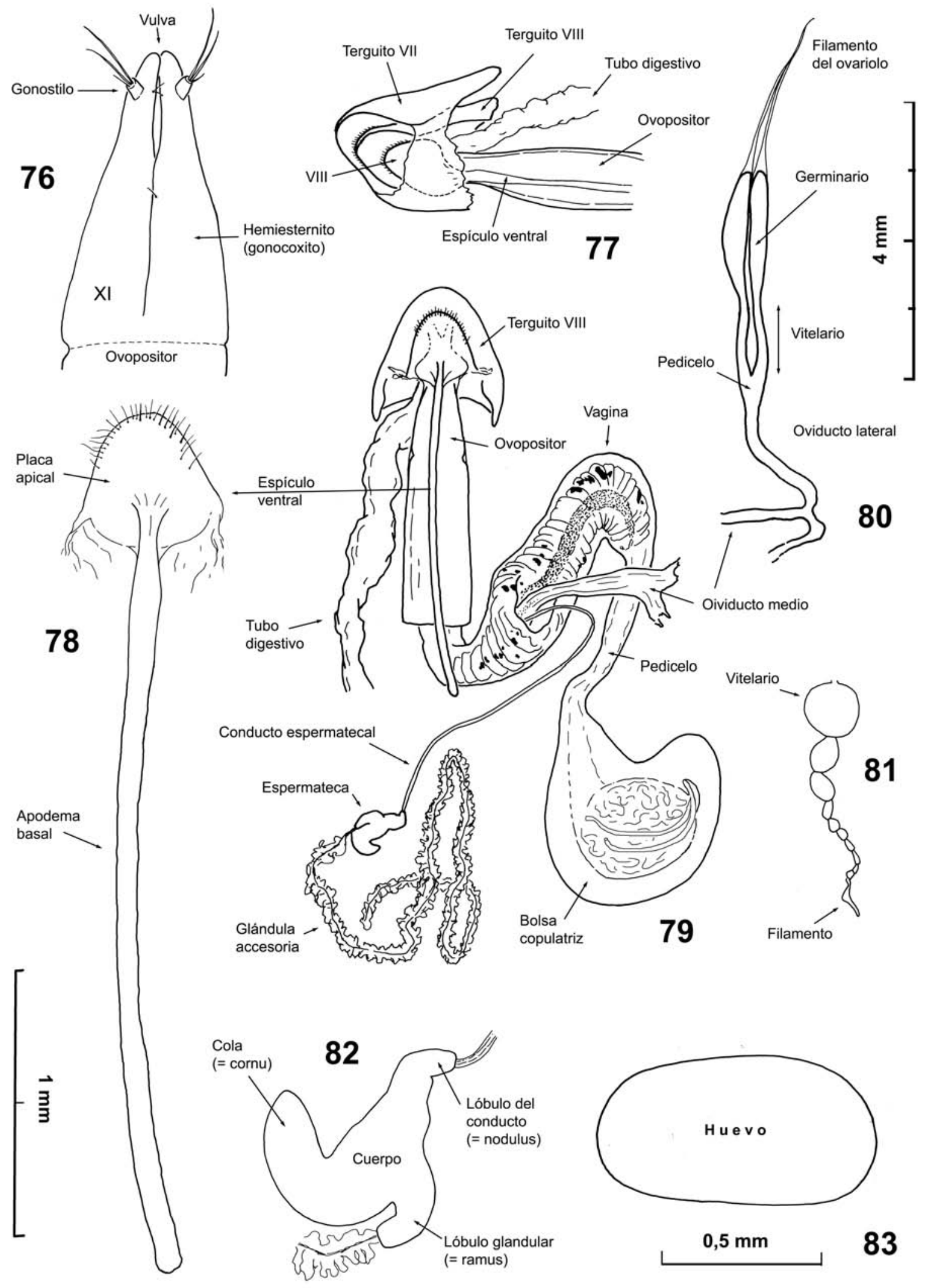


mén, 1970) y se mantienen fundidos en su base, sin que ello les impida abatirse hacia los lados para dejar expuesta la vulva. En L. undatus, no se aprecian báculos bien esclerificados a lo largo del ovipositor para darle rigidez, y los estilos (gonostyli) se emplazan preapicalmente, son muy cortos y ni siquiera alcanzan el ápice del hemisternito; en su extremo portan tres setas, dos largas y una corta. Aparte de éstas, el tegumento de los hemisternitos apenas cuenta con dos o tres setas minúsculas e inconspicuas.

Espículo ventral (figs. 78-79).- El espículo ventral (spiculum ventrale) es del "tipo 1", $s$. Yunakov \& Korotyaev (2008), y consiste en una espiga muy larga, ligeramente arqueada, que sirve de agarre a los músculos del ovipositor. Su extremo posterior se funde sobre una placa apical, tan larga como ancha, cuyo borde libre está curvado y provisto de setas cortas. Esta pieza es el esternito abdominal VIII, que ha devenido interno y cuyo borde basal se une mediante membranas a la vaina que conforma el pre-tubo del ovipositor. Sus variaciones resultan muy útiles en la sistemática de grupos en Laparocerus.

\section{El huevo}

Los huevos de L. undatus son bastante alargados, 1,9 veces más largos que anchos, y el corion es de color blanco sucio. En el interior de hembras grávidas es posible encontrar varias decenas de huevos. Se desconoce el número total de huevos que es capaz de poner una hembra; entre 40-80, o posiblemente más.

\section{La larva}

Las larvas de los Laparocerus no han sido descritas hasta la fecha. La de L. undatus es la típica de la mayoría de los curculiónidos, una larva ápoda escarabeiforme, de cabeza hipognata libre (no se retrae en el protórax), sin cercos, con antenas vesti- giales, y que alcanza una talla de $10 \mathrm{~mm}$, quizás de las mayores dentro del género. Su color es blancocremoso salvo en la cabeza pigmentada de color caramelo, empardecido anteriormente, y los tergitos terminales, ligeramente pigmentados. Algunos agricultores canarios designan de modo genérico como "arestín" a las larvas de gorgojos que viven libres en el suelo, alimentándose de raíces (Asynonychus, Brachyderes, Herpisticus, Laparocerus, Sitona, etc.).

\section{CABEZA}

La cápsula cefálica está bien esclerosada, es casi circular en vista dorsal (fig. 90), y oval-aplastada vista de perfil (fig. 84). La región dorsal está surcada en la mitad basal y al medio por la sutura epicraneal, de cuyo extremo anterior parten en "V" las dos suturas frontales, delimitando así la frente (frons), de aspecto triangular, que queda encajada entre las dos placas hemicraneales. Las suturas frontales alcanzan, pero no rebasan, la antena ("suturas incompletas", s. Anderson, 1947), y no se aprecia endocarina alguna. Carece de ocelos.

\section{Placas cefálicas}

Epicráneo.- El epicráneo está formado por dos placas que ocupan las regiones posterodorsal, lateral y lateroventral de la cápsula cefálica (fig. 90). Cada placa porta cuatro setas epicraneales dorsales (sed) largas, de las cuales la sed 3 se sitúa sobre la sutura frontal, en el borde del epicráneo; dos setas dorsolaterales ( $\mathrm{sel}$ ) medianas largas y dos ventrolaterales ( $\mathrm{sev}$ ) menores, en el ángulo anterior externo. Todas estas setas quedan emplazadas en la mitad anterior del epicráneo. En el dorso de cada hemicráneo existen además tres microsetas emplazadas a lo largo y paralelo al margen posterior, así como tres sensilos (sensilla), dos anteriores y uno mediano entre la sed1 y sed2. En la cara ventral se encuentra el foramen occipital, cordiforme, que separa las dos placas hemicraneales. El foramen

Figs. 84-89.- Aspecto general de la larva. 84) Larva madura en vista lateral. 85) Detalle de los escleritos torácicos en vista lateral (cuerpo hinchado). 86) Espiráculo torácico y $86^{\prime}$ abdominal $7^{\circ}$. 87) Espiráculo abdominal $1^{\circ}$ en vista oblicua y detalle de su apertura. 88) Detalle del extremo posterior del abdomen en vista lateral. 89) Detalle del ápice abdominal en vista posterior.

Figs. 84-89.- General aspect of the larva. 84) Mature larva in lateral view. 85) Detail of thoracic sclerites in lateral view (body inflated). 86) Thoracic spiracle and 86' abdominal spiracle 7. 87) Abdominal spiracle 1 and detail of aperture, in oblique view. 88) Detail of abdominal hind-part in lateral view. 89) Abdominal apex in posterior view. 


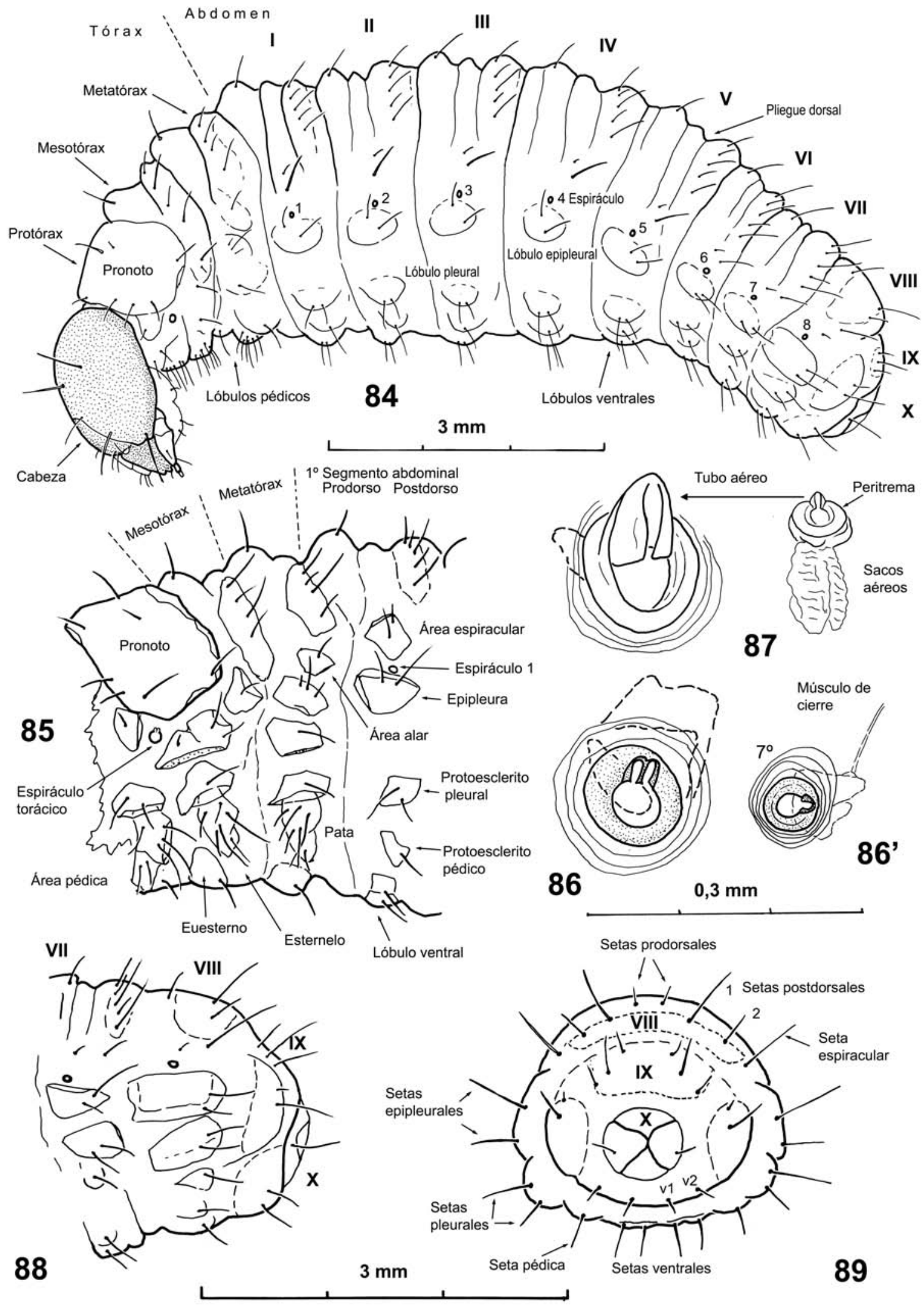


está delimitado por membranas coriáceas más o menos amplias (cervix), que en el tercio posterior forman dos lóbulos subtriangulares que se repliegan hacia el exterior, los cóndilos postoccipitales (May, 1994). La amplia lámina anterior es hialina y sus márgenes anterior y posterior son tricóncavos, siendo la escotadura posterior mediana la más amplia; es el puente tentorial. Existe otro puente membranoso en posición anterior, el hipofaríngeo, a modo de banda estrecha rectilínea con dos pequeños esclerosamientos a ambos lados de su mitad, que conecta los extremos ventro-anteriores del epicráneo, pero queda oculto en visión ventral por el labio y las maxilas.

En la región occipital, las paredes de cada hemicráneo se prolongan en el plano sagital hacia el interior de la cápsula cefálica, formando el tentorio occipital, visible a través del foramen occipital. Del extremo anterior de esta doble lámina o endocarina parten en ángulo y hacia atrás sendos brazos, mucho menos desarrollados en altura.

Frente.- La frente (frons) es amplia, triangular, con el ángulo posterior aguzado en punta. Las catapófisis antero-laterales están bien desarrolladas y esclerosadas. Existen dos pares de setas frontales: las del primer par ( $s f 1)$, submarginales, se emplazan a ambos lados de la mediana, bien separadas entre sí son y mucho más largas que las del otro par ( $s f 2)$, situadas en el margen antero-lateral junto a las catapófisis. Para la numeración de la setas se ha seguido a Van den Berg (1972); según el esquema homológico de quetotaxia de Marvaldi (2003), estas setas frontales serían la $4^{\mathrm{a}}$ y $5^{\mathrm{a}}$, respectivamente. En cada lado se distinguen 2 sensilos, uno junto a la $s f 1$ y otro posterior al mismo nivel: existen además una microseta al pie de la $s f l$ y próxima al sensilo, y tres alineadas longitudinalmente próximas a la mediana; las dos primeras más próximas entre sí, y la posterior, más cerca del ángulo frontal posterior.

Clípeo.- El clípeo tiene forma trapezoidal apaisada (casi 3x más ancho que largo), con los lados brevemente estrangulados en el margen anterior (fig. 96). Su unión con la frente genera un margen en declive, abrupto y muy esclerosado (posclípeo), sobre el que, con dificultad, se pueden distinguir a cada lado 2 pequeñas setas clipeales desiguales y un sensilo entre ellas, algo más avanzado. El anteclípeo está menos esclerotizado, salvo por una banda mediana.

Labro.- El labro se encaja en el clípeo por delante y la unión entre ambos se discierne bien, sobre todo dorsalmente; su forma es semicircularapaisada con los márgenes anteriores y laterales poco esclerosados. En la cara dorsal porta tres setas labrales a cada lado (numeradas en la fig. 96), quedando solo la mediana dentro del área esclerosada. Existe un sensilo labral impar situado en la mediana, en la base. En la cara ventral (superficie epifaríngea, fig. 95) existe un par de bastoncillos labrales bien esclerosados y enfrentados, con una ramificación corta hacia el interior, cuyo ápice, así como el de la rama principal, termina en una espina corta. Las dos espinas anteriores y más externas están el doble de separadas entre sí que las dos posteriores e internas, y en el área delimitada entre ellas existen un par de sensilos. Al medio y junto al margen labral anterior hay dos pares de setas epifaríngeas medianas anchas, y un par más (submarginal), mucho menor, junto al pie de la más interna. Hacia cada lado, se encuentra la serie de tres setas epifaríngeas anterolaterales anchas, usualmente con la punta desbastada. La superficie de las áreas marginales está provista de diminutas papilas triangulares.

\section{Piezas bucales}

Mandíbulas.- Las mandíbulas son cortas y macizas, con forma piramidal y cóncavas por su cara interna (fig. 92); están muy esclerosadas, salvo un área subtriangular en la depresión basal donde el tegumento es semi-traslúcido, lo mismo que en la cara ventral (fig. 92'). El ápice mandibular es bífido

Figs. 90-97'.- Cabeza y piezas bucales de la larva. 90) Cabeza en vista dorsal. 91) Cabeza en vista ventral. 92) Mandíbula izquierda en vista dorsal y 92' ventral. 93) Maxila izquierda en vista ventral y 93' detalle dorsal de la mala. 94) Labio en vista ventral. 95) Labro en vista ventral. 96) Parte anterior de la cabeza con clípeo y labro, en vista dorsal. 97) Detalle de las antenas en vista dorsal y 97 ' frontal.

Figs. 90-97'.- Head and mouth pieces of the larva. 90) Head in dorsal view. 91) Head in ventral view. 92) Left mandible in dorsal view, and 92' in ventral view. 93) Left maxilla in ventral view, and 93' detail of mala in dorsal view. 94) Labium in ventral view. 95) Labrum in ventral view. 96) Forehead with clypeus and labrum in dorsal view. 97) Detail of antenna in dorsal view, and $97^{\prime}$ in frontal view. 


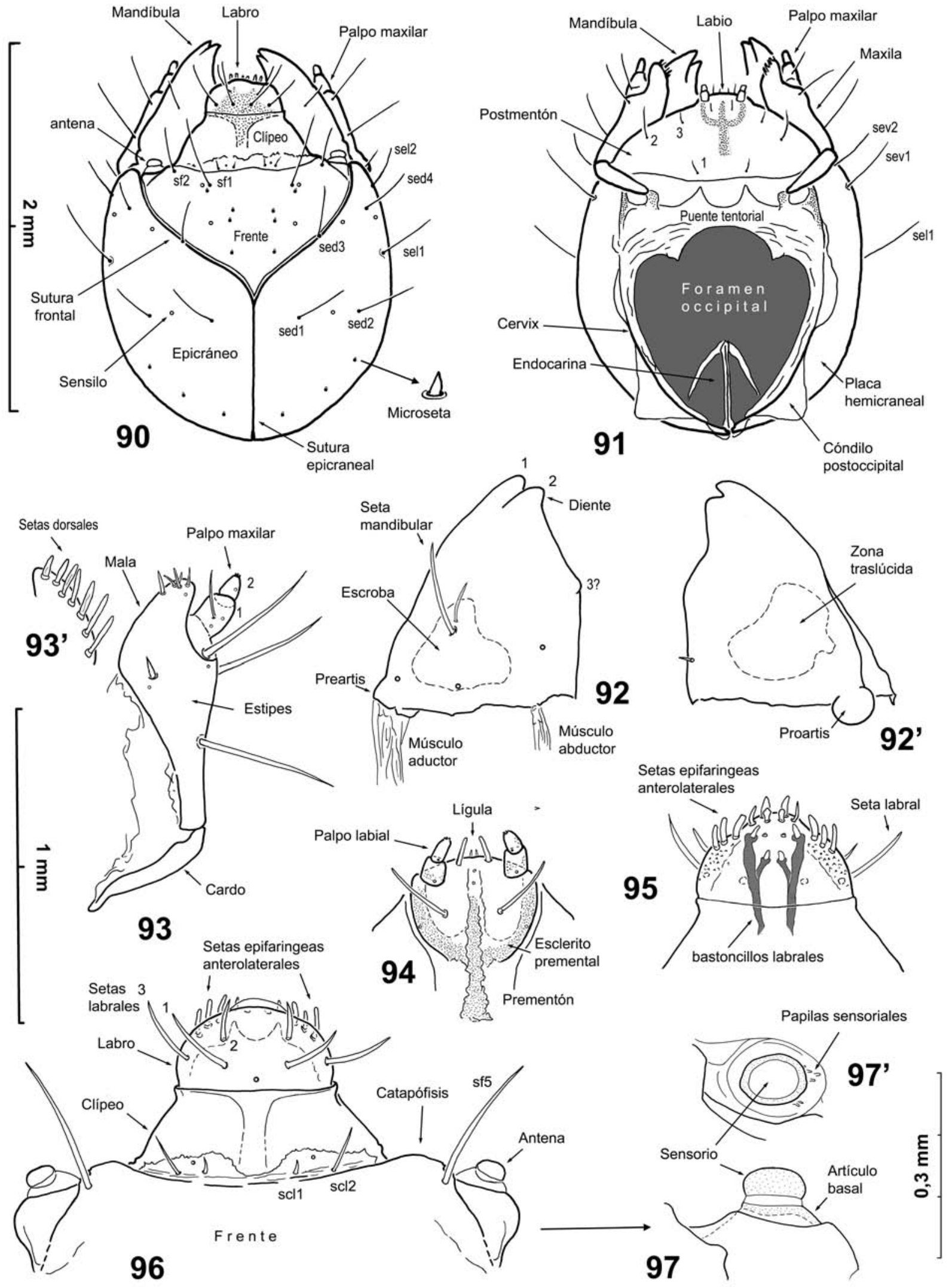


y los dos dientes son bastante romos en la larva adulta; en el canto interno masticador se aprecia hacia la mitad el indicio de un tercer diente en larvas jóvenes, luego desvastado (ángulo romo). En la cara dorsolateral, en el extremo anterior de la zona deprimida, se emplazan dos setas mandibulares, una larga y otra corta; existen además un sensilo en el ángulo posterior externo próximo al preartis, otro mediano, y un tercero casi a la altura de la seta mandibular, próximo al canto masticador. En la cara ventral hay una diminuta seta junto al canto masticador. El postartis es globular y el músculo abductor que se inserta junto a él está bastante menos desarrollado que el aductor, junto a al preartis.

Maxilas.- Como es característico de las larvas de curculiónidos (excepto Sitonini), la galea y lacinia están fusionadas para formar la mala; ésta, a su vez, se fusiona con el estipe sin que se aprecien las líneas de sutura (fig. 93). La pieza indistinta resultante tiene forma de paleta alargada progresivamente estrechada hacia la base, donde se articula en ángulo con el cardo, que es estrecho y largo. En el tercio distal, sobre una incisión abierta en el flanco externo, se inserta el palpífero, apenas esclerosado y portador de una larguísima seta palpíferal en su base. Sobre el palpífero se asienta el palpo maxilar, compuesto por un primer segmento cilíndrico con una seta bastante menor y dos sensilos, y un segundo segmento apical cónico, más corto y estrecho, con un sensilo ventral y algunas diminutas papilas apicales.

El estipe presenta dos largas setas rígidas sobre su margen externo; una mediana y otra próxima a la cavidad del palpo maxiliar, junto al sensilo estipital antero-lateral. La mala posee en su cara ventral una sola seta corta y un sensilo a su lado, además de un grupo de cinco setas apicales cortas en disposición irregular y desiguales de tamaño, más un sensilo subapical; por su cara dorsal y a lo largo del margen interno, presenta una hilera regular de siete anchas setas romas (mas anchas y largas que las ventrales), que alcanza el ápice. El tegumento en la cara dorsal (cardo incluido) está poco esclerosado y provisto de diminutos dentículos.

Labio.- En las larvas el postmentón es muy amplio (fig. 91), está apenas esclerosado y se une lateralmente al cardo y estipe de las maxilas; presenta tres pares de setas, siendo las del segundo par las más largas y externas. El prementón (fig. 94), en posición anterior, presenta una parte esclerosada en forma de tridente que es el esclerito premental, con dos sensilos apicales en la mediana de la rama central, y un sensilo marginal a mitad de altura en cada rama lateral. En la cara ventral hay un par de setas apicales cortas, y un par de setas prementonales mucho más largas, emplazadas a ambos lados de la rama media del tridente, que es de lados paralelos y está truncada y algo expandida en su extremo posterior. En la región membranosa anterior, interpretable como lígula, existen dos setas muy pequeñas. Los palpos labiales carecen de setas y están compuestos por dos segmentos, cada uno con un sensilo basal; el primero es más ancho que el segundo, que porta algunas papilas sensoriales en el ápice.

\section{Antenas}

Las antenas siempre son reducidas en todos los curculiónidos, y constan de un segmento basal y un apéndice sensorial, separados por un anillo algo esclerosado (fig. 97). El segmento basal presenta cuatro papilas sensoriales en su margen lateral externo, y dos más en posición postero-lateral (fig. 97'). El apéndice o sensorio antenal es convexo, de superficie lisa; visto de perfil tiene forma de almohadilla (más ancho que alto) y en visión apical tiene forma ovalada transversal (más ancho que largo), carácter autapomórfico de las larvas de Entiminae (Marvaldi, 1998).

\section{TÓRAX}

Salvo por el pronoto, la disposición de los protoescleritos de los segmentos torácicos resulta difícil de interpretar y se asimilan a los lóbulos visibles sobre el cuerpo de la larva (fig. 84). No obstante, los protoescleritos se reconocen bien si se hincha el cuerpo vaciado de la larva con glicerina, estirando los tegumentos y observándolos con luz lateral a la lupa (fig. 85). La descripción de la quetotaxia refiere a una mitad del segmento y las setas se suelen numerar por series, de la mediana hacia fuera.

\section{Protórax}

El pronoto es la única placa algo diferenciada del tórax al estar ligeramente esclerosada; ocupa el dorso y una buena parte del lateral del segmento. Presenta 7 setas de longitud variable, siendo la dorsal mediana la más larga. El esclerito pleural es contiguo, muy reducido y porta una seta. A su altura y por detrás se encuentra el espiráculo protorácico, que según Snodgrass (1935) se corresponde con el mesotorácico desplazado (entre el pro y mesotó- 
rax). Este espiráculo es bicameral ( $s$. Crowson, 1981), mayor que los abdominales, y los dos tubitos aéreos apuntan hacia el dorso; el peritrema se levanta sobre un pequeño tubérculo piramidal de tegumento anillado (5-7 vueltas) que destaca sobre el tegumento liso donde se emplaza. Los sacos aéreos son cortos y a nivel del mecanismo de cierre interior el lumen atricular está orlado por trabéculas radiales. El segmento protorácico es bastante más corto en su mitad ventral, donde se distingue el lóbulo pédico formado por un proto-esclerito basal con 2 setas, y otro apendicular más alargado con indicios de subdivisión y 6 setas (dos setas son largas). Existe un protosclerito esternal a cada lado, cada uno con una larga seta.

\section{Meso- y metatórax}

Los segmentos meso y metatorácicos son membranáceos y bilobulados en el dorso. El lóbulo anterior o prodorso (prodorsum) es más abultado y porta una única seta central muy grande. El lóbulo posterior o postdorso (postdorsum) cuenta con 4 setas (de arriba a abajo: corta, larga, corta y larga) sobre un protoesclerito dorsolateral. En el área alar hay un protosclerito con una seta y no existen espiráculos. En el área pleural mesotorácica existe un único protosclerito (aparentemente formado por la reunión del epipleural y pleural) alargado con $1+2$ setas (la más dorsal, siempre larga); en el segmento metatorácico, sin embargo, el esclerito epipleural (3 setas, la mediana larga) y el pleural (1 seta) están claramente separados. Los protoescleritos pédicos forman un rudimento de pata como en el protórax, salvo que el protoesclerito basal porta una única seta. El protoesternito se sitúa en posición anterior (lobulado en el metatórax), y porta 1 seta larga.

\section{ABDOMEN}

El abdomen es oblongo, grueso al medio, estrechado por detrás y aplastado en su cara ventral. Los segmentos están divididos dorsalmente por surcos transversales que delimitan tres pliegues más o menos lobulados. En los segmentos IV y V existe un primer surco que puede interpretarse como un auténtico pliegue tergal, pero que, según Anderson (1947), se corresponde con la delimitación lateral del prodorso. Los segmentos terminales VIII-X carecen de pliegues.

En el primer pliegue auténtico existe una seta prodorsal larga a cada lado de la mediana. El post- dorso se sitúa sobre el tercer pliegue y porta cinco setas (larga, corta, larga, corta y larga). En el área espiracular, por encima y distante del espiráculo, existen dos setas (la más dorsal, muy corta, la otra, larga) sobre un protoesclerito lateral apenas definido; en los segmentos VII y VIII la seta larga está desplazada hacia atrás y se alinea con la serie postdorsal. Por debajo del espiráculo se levanta el lóbulo epipleural, con dos setas epipleurales (mediana y larga); el lóbulo pleural, en posición lateroventral, porta dos setas pleurales /mediana y larga), y el lóbulo pédico que le sigue, porta sólo una seta larga. Los lóbulos esternales son alargados en sentido transversal, portan dos setas y se sitúan sobre el pliegue posterior, que corresponde al eusterno (eusternum s. Anderson, 1947); el esternelo (eusternellum) o porción posterior carece de setas.

Los segmentos VIII-X carecen de pliegues dorsales, sus escleritos están algo más esclerosados y pigmentados, y su quetotaxia es más simple (figura 88). El VIII cuenta con una seta prodorsal y solo dos postdorsales (larga y mediana) sobre un postdorso más amplio y algo más esclerosado; la seta larga del par espiracular está alineada las dos postdorsales y puede confundirse como perteneciente a esta serie. Los lóbulos epipleural y pleural son longitudinales y alargados, portando las dos setas hacia el extremo posterior.

El segmento IX es más reducido, algo cónico y truncado posteriormente; carece de espiráculo y cuenta con tres setas dorsales (mediana, larga, mediana) y dos setas (la dorsal muy pequeña) sobre un lóbulo lateral único (¿epipleural o espiracular?), $\mathrm{y}$ otras dos setas en posición ventral (fig. 89).

El segmento X, mucho menor y circular, se dispone a modo de tapa en el extremo terminal del abdomen; está dividido en diagonal en cuatro piezas triangulares nada sobresalientes, cuyas puntas convergen sobre el ano; las dos piezas laterales portan una seta larga.

El abdomen cuenta con ocho espiráculos a cada lado (figs. 84), de tamaño menor que el protorácico (fig. 86) y con un solo tubito aéreo, que emerge del peritrema a modo de mitra abierta hacia dentro (fig. 87). Existe mecanismo de cierre, como suele ocurrir en larvas de vida edáfica para evitar la penetración de agua. Los espiráculos abdominales también se emplazan sobre una ligera elevación anillada del tegumento; sus sacos aéreos son simples y reducidos, difíciles de distinguir de las tráqueas. El tubito 
aéreo de los primeros seis se dispone en orientación ligeramente dorsoposterior; esta inclinación aumenta en los espiráculos $5^{\circ}$ y $6^{\circ}$, para apuntar directamente en dirección posterior en el $7^{\circ}$ (fig. 86') y $8^{\circ}$. Los tubos traqueales ramificados están en disposición oblicua.

\section{La pupa}

La pupa de Laparocerus undatus tiene el aspecto característico de las pupas de curculiónidos, con el rostro, corto en este caso, bien destacado (fig. 98). Es de tamaño grande (longitud 10-11 mm, ancho torácico 3,5-3,8 $\mathrm{mm}$ ), blanda, de color blanco-cremoso, tornando a oscuro según se aproxima a la madurez. El tegumento presenta setas que nacen o no de pequeñas papilas cónicas y cuya disposición tiene relevancia taxonómica (las descripciones que siguen se refieren solo una mitad). La pupa se desarrolla en una pequeña cámara abierta bajo la tierra (varias pupas en cultivo fueron atacadas por nematodos diplogástridos).

\section{CABEZA}

La cabeza está completamente retraída hacia la cara ventral, reposando el rostro sobre la región prosternal, de modo que queda oculta en vista dorsal. El vértex presenta 1 seta pedunculada próxima a la línea mediana y 2 setas pequeñas laterales sin pedúnculo (fig. 99) por detrás de los ojos; 4 setas orlan el ojo en la frente, siendo pedunculada la más posterior; el rostro presenta 3 setas dorsolaterales, 1 lateral y 1 junto al borde anterior (región clipeal), y 1 ventrolateral en la pregena, ninguna de ellas pedunculada. Carece de surco frontal mediano. Las mandíbulas se reconocen bien y carecen de setas, pero las demás piezas bucales son difíciles de discernir.

Las antenas están acodadas a nivel de escapo y el funículo retraído por encima de las patas delantera y mediana, en el flanco del cuerpo. La división de los artejos del funículo es imprecisa, salvo la correspondiente al $2^{\circ}$ y $3^{\circ}$.

\section{TÓRAX}

El protórax está bien diferenciado y tiene forma semicircular, más ancho que largo, con la base ligeramente cóncava. Los pedúnculos de las setas sobresalen del margen otorgándole un aspecto erizado (fig. 100). Existen 2 setas anterolaterales y 1 preapical, 2 setas discales separadas entre sí, 2 laterales sobre el primer tercio (una pequeña), 1 al medio, más externa aún, y 2 sobre el segundo tercio (pequeña la más externa).

El mesotórax es algo más corto que la mitad del protórax y carece de escudete (leve marca transversal). Cuenta con 1 seta prodorsal (apical) 4 postdorsales (dorsolaterales), 1 "humeral" y 2 pleurales; todas brevemente pedunculadas. El espiráculo mesotorácico es mayor que los demás y se emplaza en la membrana intersegmental con el protórax.

El metatórax es la mitad de largo que el protórax y presenta igual quetotaxia que el mesotórax, salvo por la ausencia de seta "humeral" y que las dos setas pleurales quedan ocultas bajo las tecas elitrales. En la mediana de la membrana de unión con el primer segmento abdominal existe un pequeño óvalo transversal de tegumento liso, que destaca sobre el resto, que es microgranulado. Las tecas elitrales están visiblemente estriadas y discurren tangentes al cuerpo en sentido oblicuo, quedando encajadas entre la pata media y la posterior. Las alas metatorácicas son rudimentarias y asoman por debajo de las tecas elitrales, visibles solo en vista ventral. No existe espiráculo metatorácico.

Las patas están recogidas bajo el vientre y los únicos segmentos que se reconocen bien son los fémures, tibias y conjunto de los tarsos. Al igual que en la mayoría de los Curculionidae, destacan 2 setas pedunculadas sobre la cara externa distal de los fémures, la proximal algo más corta que la distal.

\section{ABDOMEN}

El abdomen lo conforman 9 segmentos que se estrechan progresivamente hacia el ápice. Los segmentos I-VI son subiguales, tan largos como el metatórácico, el VII es más largo, el VIII más corto y el IX es terminal. El segmento X está reducido a

Figs. 98-100.- Aspecto general de la pupa. 98) Pupa en vista lateral. 99) Pupa en vista ventral. 100) Pupa en vista dorsal.

Figs. 98-100.- General aspect of the pupa. 98) Pupa in lateral view. 99) Pupa in ventral view. 100) Pupa in dorsal view. 


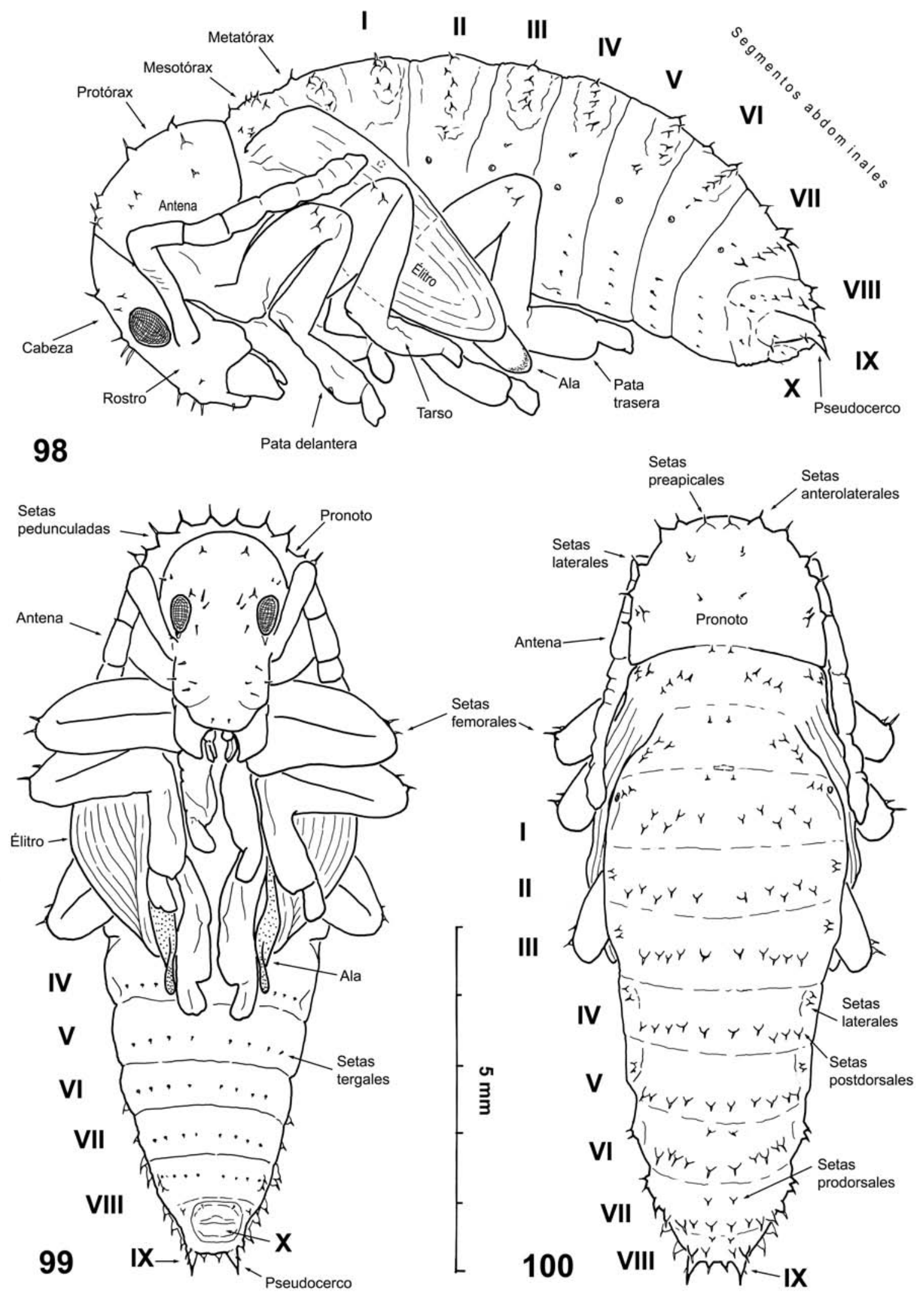


una placa circular con un surco transversal, solo visible ventralmente.

Las setas son pedunculadas en su mayoría, aumentando el tamaño del pedúnculo hacia el ápice. La quetotaxia es como sigue (una mitad): una seta prodorsal en los segmentos I (pequeña), VI, VII y VIII (?); la serie postdorsal es de cinco setas en los segmentos I-VII (alineadas solo en los posteriores), y de tres setas en el VIII. Las setas laterales (epipleurales, según algunos autores) se sitúan por encima de los espiráculos, son pequeñas y hay una en los segmentos III y IV, dos transversales en los segmentos I, II, V, y VI (la más dorsal es siempre menor), 2 dispuestas longitudinalmente en el VII (siendo la posterior grande y pedunculada, alineada con la serie postdorsal), y 2 diminutas y vestigiales en el VIII. En este último segmento, existe un par de pequeñas setas pleurales por debajo del espiráculo, que es vestigial (fig. 98). La hilera transvesal de 4 setas esternales son minúsculas, no pedunculadas, están bastante separadas entre sí y resultan difíciles de observar (fig. 99).

El segmento IX tiene una configuración especial; termina en un pseudocerco o pedúnculo cónico doble de largo que los anteriores, rematado en una seta, porta además una pequeña seta sobre su costado basal y una pedunculada externa, próxima a la base; hacia dentro existe otra seta pedunculada, de modo que el ápice abdominal termina dorsalmente en dos pseudocercos con dos setas pedunculadas entre ellos; ventralmente cuenta a cada lado con una gran seta pedunculada apical junto a otra pequeña, más interior. El segmento $\mathrm{X}$ porta un par de setas microscópicas por debajo del surco transversal mediano El conjunto de segmentos apicales (VI-IX) ofrece un aspecto bastante erizado.

Los espiráculos de los segmentos II-VIII son visibles en los flancos de la pupa, y el del segmento I, que queda tapado por la teca elitral, es el único expuesto en vista dorsal.

\section{Discusión}

La única diagnosis disponible de Laparocerini aparece en la descripción original de Lacordaire (1863): «Antenas más o menos largas y gráciles; su maza alargada y acuminada. Escudete en general visible. Élitros tanto un poco más anchos que el protórax como superándolo, con los hombros redondeados. Cestillas abiertas; uñas de los tarsos soldadas. Segundo segmento abdominal casi siempre más largo que cada uno de los dos siguientes, separado del primero por una sutura arqueada; saliente intercoxal bastante ancho, truncado por delante. Cuerpo áptero.»

Winkler (1932) no reconoce la tribu Laparocerini y, asigna Laparocerus a los Mylacini (actualmente Omiini $f$. Alonso-Zarazaga \& Lyal, 1999). Efectivamente, la separación entre las metacoxas es tan amplia como la distancia entre la meso y metacoxas, y las uñas están soldadas por la base como ocurre en Omiini, pero la escroba antenal de Laparocerus no se abre dorsalmente, lo que los aleja de este grupo.

Ante la inutilidad de la caracterización de Lacordaire y el arreglo propuesto por Winkler, la primera duda a resolver, al margen de cuestiones de prioridad, es si Laparoceus undatus, como representante del género tipo de Laparocerini, encaja en algunas de las muchas tribus de Entiminae conocidas $(>50)$, o si realmente se justifica mantener Laparocerini como taxón supragenérico diferenciado. Desafortunadamente, no existen claves que abarquen el universo completo de los gorgojos de morro corto, reflejo de la sistemática del grupo, que sigue siendo bastante caótica a juicio de algunos autores (Oberprieler et al., 2007). Ninguna de las claves recientes considera Laparocerini, y si se ensaya la determinación de L. undatus, se echa fuera o acaba forzado dentro de algún grupo, cuya ulterior comprobación diagnóstica no supera. Queda, sin embargo, la alternativa de repasar al menos aquéllos caracteres que últimamente se vienen considerando como relevantes para establecer relaciones de parentesco entre grupos de curculiónidos.

\section{LOS CARACTERES DEL IMAGO}

El insecto estudiado es un Entiminae en el sentido de Thompson (1992). Se trata de un curculiónido de morro corto (Curculiones brevirostres) que posee simultáneamente prolongaciones mandibulares dehiscentes (o la cicatriz tras haberse desprendido) y una genitalia masculina pedal (tipo "gonatócero"ex aucct.), con el lóbulo medio y espículo gastral más largo que el manubrio del tegmen.

La mayoría de los Entiminae tienen piezas bucales adelognatas, pero en Laparocerus las bases de las maxilas son visibles en el seno hipostomal a ambos lados del labio, que no las oculta. Esta con- 
dición fanerognata se da también en Sitonini, algunos Celeuthetini, en Phyllobiini y Polydrusini, y puntualmente en algunos géneros y especies no relacionados. La forma de las mandíbulas y maxilas se parecen bastante a las de Sitona (Ting, 1936), pero en Sitonini la gálea y la lacinia no están fundidas en una única mala, los palpos labiales están constituídos por tres artejos, además de presentar el ovipositor atrofiado. En Celeuthetini, las escrobas antenales son dorsales, las procoxas suelen estar separadas y las uñas son libres. En varios Phyllobius y Polydrusus, según ilustran Morimoto et al. (2006), el prementón es igualmente cordiforme, asentado sobre el pedúnculo estrecho y corto del postmentón, y con los palpos contiguos; la única diferencia notable con el de Laparocerus es que en éste no existen setas en el prementón (fig. 17). Phyllobiini tiene las escrobas antenales dorsales, y el oviscapto carece de estilos, de modo que, de este grupo de entiminos fanerognatos, queda Polydrusini como potencial grupo afín, a pesar de que son más cortos de morro, los ojos se emplazan más dorsalmente que en Laparocerus, y tienen alas funcionales.

Otros caracteres a destacar en la cabeza de $L$. undatus son: las escrobas antenales dispuestas sobre el lateral del rostro, el epistoma escotado en "V" (poco pronunciado en L. undatus), ausencia de placa rostral, seno hipostomal no desarrollado, la presencia de fóvea frontal, y la configuración del tentorio occipital (hemicónico, sin brazos, fig. 12) que no coincide con ninguna de las ilustradas por Ting (1936). La considerable longitud y delicadeza de las antenas, que dio origen al nombre de Laparocerus, ("grácil" + "cuerno"), no es en absoluto una exclusividad del género, y la esbeltez cierta de las antenas de L. undatus tampoco está generalizada entre sus congéneres, donde las hay bastante más robustas y claviformes, aunque el escapo girado hacia atrás, en posición de reposo, siempre rebasa la cabeza.

El pronoto es sencillo, sin lóbulos oculares y cerrado por detrás de los acetábulos coxales, como en Hylobius abietis (Linnaeus, 1758), por ejemplo. Según Morimoto et al. (op. cit.), el trocantín en los Polyphaga está fundido con el pleuron para formar el criptopleuron invaginado. En Laparocerus undatus el trocantín está perfectamente diferenciado y unido a la base de la procoxa; y en la mesocoxa lo mismo (figs. 42-43). En los esquemas del mecanismo pleuro-coxal que ilustra Hlávac (1972) no figura ninguno de Curculionidae, pero he comprobado en
Strophomorphus albarius (Reiche \& Saulcy, 1857), Polydrusus baudii (Faust, 1889) y Otiorhynchus ovalipennis (Boheman, 1843), la presencia de piezas equivalentes con la misma forma básica de medio cono, aunque en Otiorhynchus participan más escleritos del anillo interno o trocantinopleuritos, según interpretan Bäcker et al. (2008) la evolución de las subcoxas.

Fletcher (1965) se extraña de que de las alas metatorácicas rudimentarias que se aprecian en la pupa de muchos gorgojos, no quede luego vestigio alguno debajo de los élitros en el imago. No es el caso de Laparocerus, donde sí existe un rudimento alar (fig 38). No obstante, el metendosternito carece de brazos laterales y su conformación general se corresponde con la de un gorgojo áptero. En las ilustraciones que ofrece Morimoto (1962a) sobre esta pieza tan variable, no hay ninguna que coincida con la de L. undatus (figs. 51-52). La dibujada para Calomycterus setarius (Cyphicerini) se aproxima bastante (fig. 14 op. cit.), aunque en los ejemplares de Strophomorphus albarius (Brachyderini) que he diseccionado, tanto el metendosternito como el mesendosternito se parecen mucho más.

Los fémures clavulados de Laparocerus carecen de dientes; las tibias son mucronadas, nunca uncinadas, y presentan el área artícular oblícua, con el peine apical completo y el interior interrumpido (cestilla abierta, tipo Notarinae $s$. Morimoto 1962a); el tarso es excéntrico y las uñas están unidas por su base. Ninguno de estos caracteres es apomórfico de alguna tribu en particular; se repiten en muchas de ellas.

En el abdomen, el segundo ventrito es mucho más largo que el tercero $\left(2^{\circ}=3^{\circ}+4^{\circ}\right.$ medido en la mediana) y está unido al primero rígidamente, siendo la sutura completa y arqueada hacia delante (no recta) en su tramo medio, como ocurre en Ithycerus noveboracensis o en Otiorhynchus (Otiorhynchini). Sin embargo en este último grupo, al igual que en la mayoría de los Curculionidae, el VIII esternito está representado por dos hemisternitos más o menos unidos entre sí, carentes de apodemas, según ilustra Thompson (1992). En Laparocerus undatus no existe el esternito VIII masculino y solo queda un pequeño apodema con el extremo suelto en forma de $\mathrm{T}$ (fig 68). Consultado sobre el particular, Thompson (in litt. 14/7/2007) opina que un espículo singularizado como éste solo se conoce en algunas familias primitivas, como Nemonychidae y Urodontidae (comprobado después de su publicación de 1992), aunque en varios Curculionidae, entre ellos Entiminae, puedan 
existir varias esclerotizaciones en el mismo sitio y resulta cuestionable si se trata de estructuras homólogas al espículo relicto, que él asimila al espículo ventral de las hembras. Sugiere designarlo "median process" o con otro nombre. Wanat (2007) emplea el término de apodema pero no toma postura sobre si se trata de un espículo relicto homólogo. Deuve (1988) opina que los esternitos VIII y IX no existen en ambos sexos de Coleoptera y que lo que muchos autores consideran terguitos son lateroterguitos, y la condición dividida se puede esperar en cualquier coleópteros primitivo. Morimoto (1962a) y Morimoto et al. (1999) registran la presencia de spiculum relictum, en Nemonyx y Rhinorhynchus (Nemonychidae), Araecerus y Apolecta (Anthribidae), Rhinotia y Dicordylus (Belidae), Ithycerus (Ithyceridae) y algunos Brentidae. Según las ilustraciones de Girón \& Franz (2010) Apodrosus (¿Polydrusini?) se ha añadir a esta lista. De momento, he mantenido el término de espículo relicto, en tanto se aclara su interpretación. Como entimino, Laparocerus es un curculiónido evolucionado y, de hecho, presenta los veinticuatro caracteres derivados que relaciona Morimoto (1952b: 368), lo que no impide que coexistan con algún que otro carácter plesiomórfico, como podría ser el presente. El espículo no está acompañado de placas laterales desarrolladas, como ocurre con el apodema central de los pocos entiminos que lo presentan (p.e. Entimus nobilis). Yunakov \& Korotyaev (2008) mencionan como apomorfías de Chiloneus (Sciaphilini) el epistoma en forma de U y un spiculum relictum membranáceo, pero no aparece dibujado en la ilustración de la genitalia de Chiloneus siculus que aportan (fig 8A op. cit.). En Laparocerus, el espículo relicto parece estar presente en todas las especies, incluidas las de aquéllos subgéneros muy diferenciados, como Lichenophagus o Atlantis, que originalmente fueron descritos como géneros independientes ( $v$. Machado, 2008b).

En el canal digestivo de Laparocerus undatus se observa un proventrículo bien desarrollado del tipo más común en subfamilias de Curculionidae (tipo VI, s. Calder 1989), pero cuya zona masticadora - de placa- es muy corta y carece de dientes, siendo por el contrario frecuente en Entiminae que esté desarrollada (Velázquez de Castro, 2007). La presencia de flecos retenedores en su interior son como los que ilustra Aslam (1961) en Otiorhynchus singularis. Lo común en Entiminae, según Calder (1989), es que el tramo anterior del tubo digestivo represente entre el 5-15\% del total, y en L. undatus es del 18\%. En Merimnetes sp. existen, al igual que en L. undatus, ciegos entéricos dispuestos lateralmente en el tramo posterior del intestino medio, pero son muy largos y menos abundantes; carece además de láminas filtradoras en el proventrículo. En general, del centenar de ilustraciones que aporta Calder (fig. 49 op. cit.), el canal alimentario de Rhadinosomus lacordairei (Cyclominae: Aterpini) es la que más se asemeja al de Laparocerus undatus, incluidos los ciegos entéricos. Aslam (1961) menciona que Amblyrhinus (Cypherini) el ventrículo anterior es lobulado en hembras y liso en machos, lo que coincide en L. undatus. Es una lástima que un sistema como el digestivo, que ofrece una inusitada variación, se conozca tan poco en los diferentes grupos como para poder ser útil a la hora de establecer relaciones.

Del cordón nervioso central, cabe decir otro tanto. El de Laparocerus undatus (fig. 59) encaja en la variación de los Curculionidae, pero tampoco coincide con ninguna de las ilustraciones de Aslam (1961) y Calder (1989). El cerebro presenta pequeños lóbulos oftálmicos, el arco esófágico es amplio y largo, el ganglio protorácico se mantiene diferenciado, y el meso y metatorácico están fundidos, y los ganglios abdominales son tres, muy próximos entre sí (el segundo prácticamente fundido con el tercero). Según Aslam (1961), este esquema es el más primitivo y está presente en los gorgojos de morro corto. El mayor parecido entre los ilustrados por Calder (op. cit. fig. 121) lo ofrece Phlyctinus callosus (Oosomini), pero el cordón de unión de los ganglios abdominales es pareado, y en Laparocerus es único y algo más corto.

El conjunto gonadal masculino de L. undatus (fig. 66) corresponde en general al descrito para Entiminae por Calder (1990), pero con algunas peculiaridades que no permiten asimilarlo a ninguno concreto de los estudiados por este autor. Los dos lóbulos de cada testículo tienen forma de escudo, se disponen contiguos en el mismo plano y contienen muchos folículos pequeños (ca. 20+15); este modelo no es el más generalizado (lóbulos circulares gruesos, no alineados y separados, con 6-10 folículos) y lo presenta, por ejemplo, Phlyctinus callosus (Oosomini). Además, los conductos eferentes y deferentes de L. undatus están tremendamente hinchados individualmente. Según Calder, conductos deferentes anteriores hinchados son obvios en Nemonychidae, Anthribidae, Brentidae, 
Curculioninae y, algo menos, en algunas especies de Apionidae y Cryptorhynchinae, sin mencionar para nada a los Entiminae o comentar hinchazones equiparables en los vasos aferentes. Aslam (1961, fig. 164) dibuja vasos aferentes hinchados, aunque no tanto, en Alcidodes fabrici (Molytinae: Mecysolobini). La vesícula seminal está constituida comúnmente por ocho gruesos lóbulos transparentes adosados radialmente sobre el conducto eferente y, a veces, uno más hipertrofiado. Una vesícula seminal en forma de "racimo de uvas", como refiere Calder al amasijo que presentan Cleonini y algún Amycterinae, es lo más parecido a la descrita aquí para Laparocerus undatus. En términos generales, la ilustración de Pachycerus cordiger la recuerda bastante (op. cit., fig. 98), incluidas las dos glándulas accesorias muy largas y desparejas, con muchos bucles; pero difiere en la forma del los vasos aferentes y testículos cuyos lóbulos están separados y son circulares. Aparentemente, Laparocerus ofrece una combinación propia.

En Entiminae la conformación del edeago, y particularmente, la de su saco interno, suelen ser muy útiles en la sistemática de especies y géneros, pero menos para establecer filiaciones intergrupales. Estas variaciones se dan dentro del propio género Laparocerus. El esquema del saco interno de L. undatus, con el gonoporo emplazado en un divertículo lateral mucho más corto que el "aparentemente" principal, que es ciego y a menudo voluminoso, es el más generalizado, pero en el subgénero Atlantodes y Lichenophagus, ambos de Madeira, el divertículo gonoporal se asienta a modo de prolongación en el extremo del tubo principal, extraordinariamente largo en el caso de Lichenophagus (Machado, 2008b). La forma "lateral" en que se emplaza el gonoporo en el saco interno en Laparocerus no es contemplada en los esquemas de saco interno reseñados por Arzanov (2003). En la base del saco interno, próximo a la abertura apical (ostium penis) existe un pequeño esclerito o trabilla ostiolar que debe ser homólogo a la estructura que dibuja Morimoto et al. (2006) en varios Phyllobius, solo que en éstos es algo más robusta y descansa más dorsalmente o sobre el costado izquierdo, en vez del derecho. La forma general del lóbulo medio y el tegmen de los Laparocerus recuerda bastante a la de los Phyllobiini y Polydrusini, aunque éstos suelen presentar flagelos y aparatos transponedores en el saco interno, y a veces el ápice del lóbulo medio es trífido. Nada de esto ocurre en Laparo- cerus, aunque el ápice se curve o ensanche en formas caprichosas, que no es el caso en $L$. undatus, que lo tiene simple. Los delicados parámeros del tegmen terminan en unos pequeños flecos, visibles solo a gran aumento y en nada comparable a las setas apicales bien aparentes que portan los parámeros de gorgojos ortóceros (Thompson, 1992). Es posible que existan en otros grupos de entiminos y que hayan pasado desapercibidos dado su pequeño tamaño.

La genitalia femenina ofrece algunos caracteres interesantes. Según Aslam (1961), todos los Adelognatha (excepto Sitonini) tienen una vagina longitudinal tubular y esclerotizada, y el conducto de la espermateca es muy largo en Otiorhynchini, Brachyderini, Sitonini, Eremnus (Tanyrhynchini) y Cionini (Curculioninae); en los demás es corto (Aslam, 1961). Esta condición se da en Laparocerus undatus, donde, además, la glándula accesoria de la espermateca es extraordinariamente larga, más que el conducto espermatecal. La vagina está musculada y es bastante rígida, tiene forma de $\mathrm{Z}$ y su tramo medio es tan largo como el ovipositor. El oviducto $y$ el conducto espermatecal se insertan en ella basalmente, tras el primer codo, de manera que queda muy alejada de la enorme bolsa copulatriz que se une al otro extremo mediante un largo pedicelo. Bolsas copulatrices bien desarrolladas existen en varios grupos (v. Aslam 1961). En Polydrusus japonicus, por ejemplo (Morimoto et al., 2006: fig. 594), ocurre así, pero el oviducto se une, como suele ser común, en el extremo distal y próximo a la bolsa copulatriz; el gonoporo nunca queda tan alejado como en L. undatus (fig. 79). Los estilos son muy pequeños en esta especie, pero en otros Laparocerus son mayores, rebasan el ápice del hemisternito, o se emplazan más apicalmente. Siempre existen.

\section{LOS CARACTERES PREIMAGINALES}

Los estudios larvarios de curculiónidos han recibido mayor atención que los correspondientes a la anatomía interna del adulto, y son varios los autores que han intentado desvelar la filogenia de Curculionoidea aprovechando esta nueva información (Anderson, 1947; Van Emden, 1952; May, 1993; Crowson, 1995; Marvaldi, 1997, 1998; Morimoto et al., 2006). Las relaciones filogenéticas basadas sobre caracteres de los estadios preimaginales no siempre coinciden con las obtenidas a partir de caracteres del 
adulto (Van Emden, 1952). Esta discrepancia puede radicar, en opinión de Marvaldi (1997), en que la diferenciación larvaria precedió a la de los adultos en la filogenia, pero también a homoplasias desapercibidas, que pueden afectar tanto a larvas como a adultos.

Marvaldi (1997) realiza un análisis cladístico de los Curculionidae basado en 41 caracteres larvarios, 3 de la pupa y 5 del adulto. Entre otros resultados, concluye que los Entiminae sensu Thompson (1992) constituyen un clado natural y propone una clasificación mucho más simplificada, con solo cinco tribus segregadas en dos clados: Pachyrhynchini + Ectemmnorhinini y Alophini + Sitonini + Entimini. Los estados de los caracteres de Laparocerus undatus concuerdan con todos los atribuidos a Entimini, salvo por los siguientes:

- Maxilas de la larva con cinco y no cuatro setas ventrales en la mala (fig. 93).

- Larva con vestigios de patas incipientemente segmentadas, en vez de ausentes (fig. 84).

- Seta postdorsal 4 del segmento abdominal VIII ausente en vez de presente (fig. 88).

- Pupa sin setas en la teca mandibular en vez de tenerlas (figs. 98-99).

- El imago presenta piezas bucales fanerognatas y no adelognatas (figs. 9 y 17).

Estos cinco caracteres se manifiestan en $L$. undatus en su estado plesiomórfico y no derivado, como cabría esperar. Marvaldi (1997) plantea como apomorfías de las larvas de Entiminae la forma en almohadilla con base oval del sensorio antenal y las cuatro setas ventrales en la mala. Laparocerus cumple con lo primero, pero no con lo segundo (los Cyclominae tienen 5 setas en la mala, pero el sensilo antenal es cónico). Respecto de los otros caracteres, como el esquema adelognato de las piezas bucales o la ausencia de seta en la teca mandibular de la pupa, acepta que son homoplásicos. Por otra parte, en un trabajo posterior (Marvaldi, 1998) amplía la caracterización larvaria de la subfamilia, considerando la posición de la seta dorsal epicraneal sobre el surco frontal, la presencia de cóndilos postoccipitales, y los segmentos abdominales I-VII con 3-4 pliegues, caracteres que se dan en Laparocerus, pero no así otros dos: el sensilo entre la seta epicraneal dorsal 2 y la 4 debería estar ausente, y en el segmento abdominal VIII debería haber siempre una seta homóloga a la postdorsal $5^{\text {a }}$ de los segmentos precedentes. En el epicráneo de la larva de Laparocerus undatus (fig. 90) existe un sensilo próximo a la sed 4 que, a juzgar por el esquema de la quetotaxia larvaria de Marvaldi, correspondería a la quinta y la cuatro estaría ausente (salvo que se interprete como tal a la lateral $1^{\mathrm{a}}$, desplazada); en cualquier caso, hay un sensilo en esta área además del situado entre la sed 1 y sed2, y el que se sitúa próximo a la sed3 junto al surco frontal. El segmento abdominal VIII (figs. 88-89) presenta solo dos setas postdorsales, una larga y otra corta, y la tercera que está alineada con ella hay que interpretarla como la seta larga del par espiracular que ya en el segmento VII se desplaza hacia atrás alineándose con la serie postdorsal. De hecho, esta seta nace fuera del esclerito postdorsal, que se distingue bien por estar ligeramente esclerosado.

En cualquier caso, los estadios preimaginales de Laparocerus undatus encajan en los Entimini (sensu Marvaldi), antes que en Alophini o Sitonini, y a ello se suma la posición lateral -no dorsal- de los espiráculos del octavo segmento abdominal (May, 1993).

Marvaldi (1998) propone igualmente una reagrupación interna del universo de los Entimini basada en los caracteres larvarios y distingue solo tres grupos de larvas: A B y C. Estos grupos combinan o incluso desagregan varias de las tribus y subfamilias tradicionales (i.e. Otiorhynchinae, Brachyderinae) establecidas sobre los caracteres del imago. De momento, Marvaldi define los grupos larvarios y deja pendiente su posible designación como subtribus "Polydrosina", Entimina y "Barynotina", respectivamente. Según las claves que aporta, la larva de Laparocerus undatus pertenecería al grupo A, pues existe una sola seta alar (fig. 85) y las setas hipofaríngeas medianas están más separadas que las posteriores, con algunos sensilos entre medio (fig. 95). Este grupo A o posible "Polydrosina" incluye géneros como Polydrusus, Barypeithes, Sciaphilus, Strophosoma, Brachyderes (= Thylacites), Otiorhynchus, Phyllobius, y Trachyphloeus, con los que, según se expuso al discutir los caracteres del adulto, Laparocerus tiene mayor afinidad morfológica que con otros.

Cabe reseñar, que los bastoncillos labrales de $L$. undatus se parecen bastante a los que dibuja May (1993) para Phlyctinus callosus (Oosomini), sin embargo, son más rectos y divergentes, con un breve brazo lateral mediano sobre el que se asienta la seta posterior. También el apéndice posterior del esclerito premental es más largo y ensanchado hacia su ápice.

Salvo por la ausencia de seta mandibular, la pupa de Laparocerus undatus encaja bien en Entiminae: 
presenta dos setas en el ápice femoral y la teca alar no cubre el último par de patas. Destacan también la ausencia de escudete y los dos pseudocercos que emergen en el extremo abdominal de la pupa, como ocurre en varios entiminos (p. ej. Otiorhynchus o Phyllobius; Scherf, 1964: figs. 455, 461, 466, etc.).

\section{LOS CARACTERES MOLECULARES}

Los caracteres moleculares son una importante fuente complementaria de información sobre las especies y ayudan sobremanera a inferir las homoplasias morfológicas y a reconstruir las filogenias de modo más natural (e.g., Marvaldi et al., 2002). Ello abre la posibilidad de localizar el pariente más cercano de Laparocerus por la vía molecular, aunque en estudios filogenéticos es preciso contar con muestras amplias y representativas de los grupos sujetos a análisis $\mathrm{y}$, por lo común, no basta con emplear un solo marcador. Hundsdorfer et al. (2009) y McKenna et al. (2009) y han realizado los mayores análisis moleculares de los Curculionoidea hasta el presente (157 y 135 especies, respectivamente), intentando superar este tipo de dificultades o la saturación de la señal del 16S que surgen cuando el muestreo es amplio. Es una lástima que no incluyeran Laparocerus en su estudio, pero al menos en ambos trabajos Cyclominae, Entiminae, e Hiperini forman un clado, que los primeros autores tratan como Entiminae sensu lato (incluyen también a Myllorhinus), y al que los segundos añaden Gonipterini.

En el estudio filogenético molecular del género Laparocerus vengo empleando secuencias parciales de los genes mitocondriales 16SrRNA y COII, complementados con alguna muestra de un gen nuclear (factor de elongación alfa) para intentar resolver relaciones más basales. Los resultados del clado maderense ya han se han dado a conocer (Machado et al., 2008; Machado, 2008b) y los del clado canario-africano, aunque disponibles, siguen pendiente de publicación. De momento, se confirma la monofilia de ambos clados y la estrecha relación entre ellos una vez eliminado de Laparocerus el subgénero Drouetius Méquignon, 1942 de las Azores, que apenas guarda relación con el grupo (Machado 2009).

El conocimiento genético sobre los Curculiónidos es todavía muy limitado ( $v$. Gómez Zurita \& Galián, 2005). El número de secuencias disponibles en GenBank apenas abarca una escasísima muestra de la enorme diversidad tribal que se da en Entiminae, además de que no siempre coinciden sobre el mismo marcador. La búsqueda de secuencias homólogas a la de Laparocerus undatus se realizó en el ámbito del gen 16S rRNA, por contener más variedad que las de mtCOII. Los resultados del BLAST son desalentadores. Las únicas relaciones de identidad significativas aportadas por BLAST se establecen con otras especies de Laparocerus (Id. max. 98-91\%), y las de otros géneros son inferiores al 90\%) y más o menos equivalentes, sin que ninguno destaque de manera clara sobre el otro. La única especie que supera el $90 \%$ de identidad es Brachyderes incanus. Es una lástima que no existan secuencias disponibles de géneros como Chiloneus, Pholicodes o de las ramas africanas de Entimini.

En la Tabla 1 se muestran las divergencias géneticas (16SrRNA) halladas entre Laparocerus undatus y diecinueve géneros de Entimini, indicando a la tribu de Entiminae a la que pertenecen ( $s$. AlonsoZarazaga \& Lyal, 1999) y a los grupos larvarios de Marvaldi (1998). Se añadieron a la tabla Sitona (Sitoninae), además de Brachycerus lutosus (Brachycerinae), este último como grupo externo. La muestra es obviamente escasa, pero no hay mucho donde escoger.

La distancia entre Laparocerus undatus y $L$. canariensis, ambos del archipiélago canario, es del orden del $2 \%$, y con L. madeirensis del archipiélago madeirense, es inferior al 7\%. Por encima de este umbral, entre el 8 y el 9\%, se sitúa Philopedon plagiatum (Cneorhinini), y con divergencias entre el $9 \mathrm{y}$ el 9,5\%, Brachyderes incanus (Brachyderini), Barynotus moerens (Geonemini), Sciaphilus asperatus (Sciaphilini), Trachyphloeus scabriusculus (Trachyphloeini), Otiorhynchus sulcatus (Otiorhynchini) y Strophosoma melanogrammum (Brachyderini). Tanto Philopedon como Barynotus pertenecen al grupo larvario $\mathrm{C}$, con las setas hipofaringeas alineadas de otro modo, dos setas alares, etcétera, demostrando una vez más que los caracteres morfológicos y moleculares no siempre son coherentes. Los demás géneros presentan divergencias superiores al 10\%, llamando la atención Polydrusus y Phyllobius, con distancias del 10,8\%, bastante altas a pesar de la semejanza entre sus piezas bucales o genitalia y las de Laparocerus undatus. Las discrepancias con la sistemática inferida de la morfología reflejan que la señal molecular disponible es del todo insuficiente para reflejar las relaciones naturales, o que la interpretación que hacemos de los estados derivados $\mathrm{y}$ 
Tabla 1.- Divergencia genética entre Laparocerus undatus y otros curculiónidos, basada en la comparación de la secuencia parcial de $16 \mathrm{SrRNA}$, ordenadas de menor a mayor. Tribus según Alonso-Zarazaga \& Lyal (1999) y grupos larvarios de Entimini sensu Marvaldi (1998).

Tabla 1.- Genetic divergence of Laparocerus undatus with other curculionids, based on the comparison of partial sequences of the 16SrRNA, in increasing order. Tribbes according Alonso-Zarazaga \& Lyal (1999) and larval groups of Entimini sensu Marvaldi (1998).

\begin{tabular}{lllll}
\hline Especie & GenBank & Distancia & Tribu & Larva \\
\hline Laparocerus canariensis Boheman, 1842 & EF683419 & $2,0 \%$ & Laparocerini & A \\
Laparocerus madeirensis Machado, 2008 & EF583408 & $6,9 \%$ & Laparocerini & A \\
Philopedon plagiatum (Schaller, 1783) & AJ 495514 & $8,6 \%$ & Cneorhinini & C \\
Brachyderes incanus Flach, 1907 & AJ495503 & $9,1 \%$ & Brachyderini & A \\
Barynotus moerens (Fabricius, 1792) & AJ495512 & $9,1 \%$ & Geonemini & C \\
Sciaphilus asperatus (Bonsdorff, 1785) & AJ495502 & $9,1 \%$ & Sciaphilini & A \\
Trachyphloeus scabriusculus (Linnaeus, 1771) & AJ495516 & $9,3 \%$ & Trachyphloeini & A \\
Otiorhynchus sulcatus (Fabricius, 1775) & AJ495482 & $9,6 \%$ & Otiorhynchini & A \\
Strophosoma melanogrammum (Forster, 1771) & AJ495505 & $9,8 \%$ & Brachyderini & A \\
Malvinius sp. & FM994882 & $10,3 \%$ & Tropiphorini & B \\
Omias rotundatus (Fabricius, 1792) & AJ495515 & $10,3 \%$ & Omiini & A \\
Barypeithes araneiformis (Schrank, 1781) & AJ495500 & $10,5 \%$ & Sciaphilni & A \\
Rhyncogonus excavatus Van Dyke, 1937 & EF583435 & $10,5 \%$ & Rhyncogonini & C \\
Polydrusus undatus (DeGeer, 1775) & AJ495496 & $10,8 \%$ & Polydrusini & A \\
Phyllobius pyri (Linnaeus, 1758) & AJ495491 & $10,8 \%$ & Phyllobiini & A \\
Tanymecus palliatus (Fabricius, 1787) & AJ495507 & $11,0 \%$ & Tanymecini & C \\
Peritelus leucogrammus (Germar, 1824) & AJ495484 & $11,3 \%$ & Peritelini & A \\
Cylindrorhinus biangulatus Champion, 1918 & FM994720 & $12,0 \%$ & Cylydrorhinini & B \\
Psallidium sp & AJ495513 & $12,0 \%$ & Psallidini & C \\
Sitona suturalis Stephens, 1731 & Aj495510 & $12,7 \%$ & Sitoninae & - \\
Leptopius sp. & AJ495487 & $13,2 \%$ & Tropiphorini & B \\
Brachycerus lutosus Gyllenhal, 1833 & AJ495597 & $15,0 \%$ & Brachycerinae & - \\
Diaprepes abbreviatus (Linnaeus, 1758) & EF042125 & $15,7 \%$ & Eustylini & C \\
\hline
\end{tabular}

plesiomórficos de algunos caracteres morfológicos no es del todo acertada.

Los árboles filogenéticos obtenidos mediante Paup (máxima parsimonia) o con MrBayes, son absolutamente inútiles por lo reducido de la muestra. Todas las relaciones basales entre los géneros evaluados -incluidos Laparocerus y Brachyderesquedan sin resolver. Lo mismo se observa en los once Entiminae incluidos por Marvaldi et al. (2002) en su estudio morfogenético de los Curculionoidea, a pesar de que sus secuencias son más largas. En el ensayo por mí realizado solo se obtienen vinculaciones significativas por pares entre las especies de los siguientes géneros: Omias y Phyllobius $=1.00$; Sciaphilus y Trachyphloeus $=$ 1.00 ; Barynotus y Rhyncogonus $=0.97$, y Peritelus y Cylydrorhinus $=0.96$ (valores expresados en probabilidad posterior bayesiana). Nótese que en esta última pareja, Peritelus pertenece al grupo larvario
A y Cylydrorhinus al grupo B, lo que cuestiona la solidez de estos grupos.

En su estudio sobre Pachyrhinus lethierryi, un Polydrusini, Gosik et al. (2010) presentan un reducido árbol filogenético (NJ) basado en el gen mitocondrial COII. En él incluyen algunas especies de Laparocerus, que se relacionan con Barynotus moerens, pero de modo nada significativo.

\section{EL CONCEPTO DE LAPAROCERINI}

El presente estudio morfológico supone un avance neto en el conocimiento de la anatomía de Laparocerus undatus en sus fases de larva, pupa y adulto. Sin embargo, ni el análisis de los caracteres morfológicos, ni las pruebas moleculares realizadas han permitido localizar un género de curculiónido claramente relacionado con Laparocerus y cercano desde el punto de vista filogenético. Los indicios 
derivados de los caracteres del adulto, de la larva y los moleculares, no son coincidentes ni apuntan a una tribu en particular. Así, por ejemplo, las piezas bucales fanerognatas de Laparocerus muestran semejanzas importantes con Polydrusini o Phyllobiini, pero los datos moleculares o la anatomía interna (digestivo, p.ej.) apuntan hacia una relación más cercana con otras tribus, como Brachyderini o Sciaphilini, que las tienen adelognatas.

Laparocerus undatus es un gorgojo de morro corto, encuadrable en los Entiminae siempre que se amplíe el concepto de este grupo para dar cabida a varios caracteres en estado plesiomórfico, particularmente en la larva. Se justifica el mantener Laparocerini como una tribu o subtribu independiente, según se consideren los entiminos en la jerarquía taxonómica al uso. La tribu Laparocerini podría ocupar una posición basal dentro de los entiminos, ya que conserva caracteres supuestamente primitivos, que en las restantes tribus aparecen como derivados; dicho esto con las debidas cautelas, toda vez que el conocimiento de la cincuentena de tribus aceptadas -y más de mil cien géneros- no es nada homogéneo. Inquieta particularmente lo poco estudiada que está la fauna africana y parte de la antigua cuenca del Tethys, de donde, por simple lógica biogeográfica, debió de proceder la línea colonizadora de los Laparocerus macaronésicos.

A falta de confirmarlo en el conjunto de especies del generotipo, los Laparocerini podrían caracterizarse por presentar piezas bucales fanerognatas (maxilas visibles a ambos lados del prementón), prolongación mandibular dehiscente (o su cicatriz); escapo antenal largo (rebasando hacia atrás la cabeza); ojos y escrobas laterales (no dorsales), sutura entre el primer y segundo ventrito sinuosa al medio, éste tan largo como el tercero y cuarto reunidos; fémures sin dientes; tibias mucronadas sin espuelas, con cestilla abierta; uñas soldadas; zona de placa del proventrículo no diferenciada; esternito VIII masculino membranoso (sin hemiescleritos diferenciados) y con un espículo relícto mediano; edeago estilizado con saco interno sin flagelo ni aparato transponedor; tegmen con dos parámeros digitiformes y manubrio largo; ovipositor largo, siempre con gonoestilos; glándula espermática muy larga, bolsa copulatriz bien desarrollada y distante del gonoporo; larva con antenas de base oval y forma almohadillada, y mala con cinco setas ventrales; pupa sin surco rostral, setas pedunculadas, sin setas en las mandíbulas y con un par de pseudocercos terminales.
Con esta definición de Laparocerini, parece acertada la exclusión de los géneros propuesta por otros autores, tal como se comentó en la introducción: Pholicodes y Epiphaneus transferidos a Brachyderini, Aomus a Sciaphilini, Elytrodon a Omiini y Aprepes a Phyllobiini.

El Dr Ramamurthy ha tenido a bien facilitarme ilustraciones de la anatomía de Cyrtozemia dispar realizadas por su colega Dr G. Mahendiran (India), donde se ven hemisescleritos en el segmento VIII del macho, y la ausencia del espículo relicto. Este carácter es posiblemente el más fiable para reconocer un Laparocerini, según el concepto que aquí se propone. Consecuentemente, propongo excluir a Cyrtozemia de Laparocerini.

Otro tanto habría que hacer con el género australiano Merimnetes. La estructura del morro, el tipo de escamas, la disposición del ventrito $1^{\mathrm{o}}$ y $2^{\circ}$, el ápice elitral retraído, el mucrón tibial en posición apical y, sobre todo, la conformación de su tubo digestivo y de la genitalia, con testículos poliglobosos, glándulas anejas cortas y la vesícula seminal lobulada (Calder, 1989, 1890), nada tienen que ver con los de Laparocerus.

Toda esta acumulación de diferencias parecen justificar la exclusión de Merimnetes de la tribu Laparocerini, lo mismo que Neomerimnetes, género igualmente de origen australiano y próximo al anterior, con el mismo tipo de escamas, sutura recta entre el ventrito 1 y 2, ausencia de escudete, etcétera (Blackburn, 1900). A juicio de Miguel A. AlonsoZarazaga (in litt.) estos géneros parecen estar más relacionados con Leptopius Oke, 1951 (Tropiphorini) de Nueva Zelanda y Australia.

Quedan otros tres géneros de los actualmente atribuidos a Laparocerini, que no han sido cuestionados. Se trata de entiminos africanos: Aphyonotus de Etiopía, Asmaratrox de Eritrea y Straticus de Zaire. La existencia de Laparocerini en África sería, en principio, mucho más razonable que en Oceanía. Desconozco las razones por las que Lona (1938) los atribuye a esta tribu; tal vez por la forma grácil de las antenas o la conformación de las escrobas.

De estos tres genéros, sólo he podido estudiar una hembra inmadura y dañada Aphyonotus zophosoides Faust 1895. La distancia entre las metacoxas es extraordinariamente amplia, mayor que la longitud del primer ventrito al medio, como en $\mathrm{Bra}$ chycerus barbatus o Synthocus truncatus (ambos Brachycerinae), según ilustra Thompson, 1992), 
aunque en Aphyonotus todo el abdomen es marcadamente triangular. Además, el primer ventrito es igual de largo que los tres siguientes reunidos; la sutura entre el $1^{\circ}$ y $2^{\circ}$ es prácticamente rectilínea, y el $2^{\circ}$ apenas más largo que el $3^{\circ}$. La estructura de la genitalia femenina es muy distinta a la de Laparocerus. Los terguitos y estenitos VIII son del tipo C ( $s$. Yunakov \& Korotyaev, 2008), característico en las especies adaptadas a poner huevos en los suelos áridos. La lámina del octavo esternito de la hembra termina en punta aguzada y comprimida lateralmente (a modo de proa de barco) con el apodema prolongado hasta la misma punta; los hemisternitos están comprimidos lateralmente y los estilos portan 2 setas terminales y 3 laterales. Además, en Aphyonotus zophosoides la vagina es muy corta, la espermateca es tubular y alargada, próxima a la base del oviscapto. Este género también debe excluirse de Laparocerini.

Heller (1909) destaca de Asmaratrox que la sutura metaepisternal no es visible a todo su largo como en Laparocerus, y el segundo ventrito es de igual longitud que el tercero (no mayor); en relación a Straticus, apunta que el morro queda separado de la cabeza por un surco transverso y que carece de escudete. Estas diferencias son importantes, pero quizás no suficientes para separarlos de Laparocerini sin haber comprobado cómo son sus respectivas genitalias y, particularmente, el esternito VIII masculino. En la Tabla 2 se resume cómo quedaría la tribu Laparocerini a la luz de los cambios aquí comentados.

\section{EL CONCEPTO DE LAPAROCERUS}

Al centrarse el presente estudio en una única especie, Laparocerus undatus, no se pueden extrapolar sus caracteres críticos al conjunto de todos los Laparocerus conocidos, aunque el más significativo de ellos, la presencia de espículo relicto sobre el esternito VIII membranáceo, sí parece ser una generalidad en el grupo. La caracterización del género Laparocerus no es fácil, y se abordará en futuros trabajos. Algunos de los actuales subgéneros fueron originalmente descritos como géneros independientes (Lichenophagus Wollaston, 1854; Atlantis Wollaston, 1854; Cyphoscelis Wollaston, 1854 = Laparocerus; Amphora Wollaston, 1864 = Laparocerus (Guanchotrox), y Anillobius Fauvel, 1907), reconociendo así las notables diferencias morfológicas externas que existen entre ellos. Anillobius figura en el catálogo de
Alonso-Zarazaga \& Lyal (1999) como incerta sedis. Ensayos moleculares posteriores a la publicación de Machado et al. (2008) ubican a este género edáfico dentro del clado maderense de Laparocerus (datos sin publicar).

Cabe preguntarse si realmente nos encontramos ante un único género, Laparocerus, muy plástico y rico en subgéneros (18 en mi esquema provisional), o si por el contrario se trata de varios géneros de Laparocerini, muchos aún pendientes de describir. Esta es una cuestión pendiente que no puedo responder sin concluir el estudio filogenético molecular y, particularmente, sin haber ajustado el reloj molecular de este grupo y estimado la edad de sus grandes divisiones. Las hipótesis alternativas son dos:

A Todos los Laparocerus se han originado a partir de una misma línea ancestral que llegó a Madeira y a Canarias donde radió in situ generando múltiples ramas (subgéneros); todos serían neoendemismos.

B Los Laparocerini eran un grupo africano rico en géneros y una muestra de él logró colonizar las islas, asentándose y radiando a menor escala; luego, el grupo se extinguió en el área matriz como consecuencia de los cambios climáticos continentales; el resultado sería un conjunto de paleo y neoendemismos.

Para la Sistemática fenética, el género tiene un claro fin utilitario en la medida que facilita la separación entre "cosas" fenéticamente distintas. Sin embargo, según la moderna Sistemática cladista, el género, como unidad taxonómica, ha de reunir especies en grupos naturales monofiléticos (aunque algunos autores, p.ej. Anderson, 1987, admiten géneros parafiléticos), y debería además reflejar en lo posible la historia y repartición de las especies que agrupa. Si atribuimos a la especie la unidad filética en la evolución, el género podría hacer de unidad biogeográfica.

En el supuesto A, y por muy diferentes morfológicamente que sean los productos de la radiación evolutiva, expresaría mejor lo sucedido el mantener un género con múltiples subgéneros, resaltando así el fenómeno de radiación insular, tan común en archipiélagos oceánicos. Si fuera cierta la hipótesis $\mathrm{B}$, se justificaría establecer tantos géneros como líneas colonizadoras diferenciadas se detectasen. Éstas se pueden reconocer, por ejemplo, si el tiempo de segregación calculado con el reloj molecular supera la edad de los archipiélagos. En tal caso, los 
Tabla 2.- Resumen de las modificaciones habidas en la atribución de taxones a la tribu Laparocerini.

Tabla 2.- Summary changes in the attribution of taxa to the tribe Laparocerini.

\begin{tabular}{|c|c|c|c|}
\hline Tribu Laparocerini & Distribución & Status & Referencia \\
\hline Laparocerus Schönherr, 1834 & Macaronesia & Género tipo de Laparocerini & \\
\hline Lichenophagus Wollaston, 1854 & Madeira & Subgénero de Laparocerus & Machado et al., 2008 \\
\hline Cyphoscelis Wollaston, 1854 & Madeira & $=$ Laparocerus s. str. & Machado et al., 2008 \\
\hline Atlantis Wollaston, 1854 & Madeira & Subgénero de Laparocerus & Lacordaire, 1863 \\
\hline (= Amphora Wollaston, 1864) & Canarias & $\begin{array}{l}\text { = Guanchotrox Alonso-Zarazaga \& } \\
\text { Lyal, 1999. Subgénero de Laparocerus }\end{array}$ & Lona, 1938 \\
\hline Anillobius Fauvel, 1907 & Madeira & Subgénero de Laparocerus & Machado (i.l.) \\
\hline Asmaratrox Heller, 1909 & Eritrea & Pendiente de confirmación & \\
\hline Straticus Pascoe, 1886 & Zaire & Pendiente de confirmación & \\
\hline \multicolumn{4}{|l|}{ Taxones excluidos } \\
\hline Laparocerus (Drouetius Méquignon, 1942) & Azores & ¿Peritelini? & Machado, 2009 \\
\hline Aprepes Schönherr, 1847 & Europa oriental & Phyllobiini & Lona, 1938 \\
\hline Elytrodon Boheman, 1843 & Mediterráneo oriental & Omiini & Lona, 1938 \\
\hline Pholicodes Schönherr, 1826 & Mediterráneo oriental & Brachyderini & Lona, 1938 \\
\hline Epiphaneus Schönherr, 1842 & Mediterráneo oriental & Brachyderini & Lona, 1938 \\
\hline Aomus Schönherr, 1834 & Mediterráneo oriental & Sciaphilini & $\begin{array}{l}\text { Yunakov \& } \\
\text { Korotyaev, } 2008\end{array}$ \\
\hline Edmundia Faust, 1891 & Cáucaso, Somalia & Sciaphilini & Lona, 1938 \\
\hline Mitophorus Gerstaecker, 1855 & África oriental & Peritelini & Lona, 1938 \\
\hline Aphyonotus Faust, 1895 & Etiopía & Se propone la exclusión & este trabajo \\
\hline Cyrtozemia Pascoe, 1872 & India & Se propone la exclusión & este trabajo \\
\hline Merimnetes Schönherr, 1842 & Australia & Se propone la exclusión & este trabajo \\
\hline Neomerimnetes Blackburn, 1900 & Australia & Se propone la exclusión & este trabajo \\
\hline
\end{tabular}

géneros debieron formarse en África antes de poblar los archipiélagos, y posiblemente hubo más géneros, actualmente extinguidos o pendientes de descubrir. Hasta el momento solo se conoce Laparocerus susicus (Escalera, 1914) en Marruecos occidental, pero se trata aparentemente de una retrocolonización a partir de las Canarias orientales.

\section{Agradecimientos}

Quiero expresar mi agradecimiento al Dr. Miguel Ángel Alonso-Zarazaga (Museo Nacional de Ciencias Naturales, Madrid) por la discusión estimulante de este manuscrito, así como a otros colegas que han aportado información y sugerencias, aunque me consta que no siempre estarán conformes con las interpretaciones que de ellas he hecho. Mi reconocimiento al Dr. Richard Thompson (Museo de Historia Natural, Londres), a la Dra. Adriana Marvaldi (Instituto Argentino de Investigaciones de Zonas Áridas, Mendoza), a la Dra. Anna Hundsdörfer (Museum für Tierkunde, Dresden) y al Dr. Vilayanoor V. Ramamurthy (Indian Agriculture Research Institute, Nueva Delhi). El Dr. Enzo Colonelli (Roma) me facilitó ejemplares de Aomus, Merimnetes y Aphyonotus, de su colección.

\section{Referencias}

Alonso-Zarazaga, M. Á., 1989. Pseudopiezotrachelus frieseri nouvelle espèce d'Apionidae (Coleoptera) du Nepal. Bulletin de la Societé entomologique de France, 93(5-6): 167-173.

Alonso-Zarazaga, M. Á., 2007. On terminology in Curculionoidea (Coleoptera). Boletín de la Sociedad Entomológica Aragonesa, 40: 210

Alonso-Zarazaga, M. Á. \& Lyal, C. H. C., 1999. A world catalogue of families and genera of Curculionoidea (Insecta: Coleopotera) (Excepting Scolytidae and Platypodidae). Entomopraxis. Barcelona. 315 pp.

Anderson, R. S., 1987. Systematics, phylogeny and biogeography of New World weevils traditionally of the tribe Cleonini (Coleoptera, Curculionidae, Cleoninae). Quaestiones Entomologicae, 23(4): 431-709.

Anderson, W. H., 1947. A terminology for the anatomical characters useful in the taxonomy of weevil larvae. Proceedings of the entomological Society of Washington, 49: 123-132.

Arnett, R. H. jr., 1963. The beetles of the United States. A manual for identification. Catholic University of America Press. Washington D.C. 1112 pp. 
Arzanov, Y. G., 2003. Use of the endophallus characters in the systematics of the Rhynchophorous beetles (Coleoptera, Curculionoidea). Entomological Review, 83(8): 930-944 [traducido de Entomologicheskoe Obozrenie, 2003, 82(3): 7001-719].

Aslam, N. A., 1961. An assessment of some internal characters in the higher classification of the Curculionidae s.l. (Coleoptera). Transactions of the Royal Entomological Society of London, 113(14): 417-480.

Bäcker, H., Fanenbruck, M. \& Wägele, J. W., 2008. A forgotten homology supporting the monophyly of Tracheata: The subcoxa of insects and myriapods revisited. Zoologischer Anzeiger, 247: 185-207.

Balfour-Browne, F., 1961. The metendosternite in the Coleoptera. Journal of the Linnean Society of London, Zoology, 44: 337-354.

Bargagli, P., 1883. Rassegna biologica dei Rincofori europei. Bollettino della Società entomologica italiana, 16: 301-326.

Blatchley, W. S. \& Leng, C. W., 1916. Rhynchophora or weevils of North Eastern America. The Nature Publ. Co. Indianapolis. $682 \mathrm{pp}$.

Blackburn, T., 1900. On some new genera and species of Australian Coleoptera. Proceedings of the Royal Society of Victoria (N.S.), 12(2): 206-223.

Calder, A. A., 1989. The alimentary canal and nervous system of Curculionoidea (Coleoptera): gross morphology and systematic significance. Journal of Natural History, 23: 1205-1265.

Calder, A. A., 1990. Gross morphology of the soft parts of the male and female reproductive systems of Curculionoidea (Coleoptera). Journal of Natural History, 24: 453-505.

Damoiseau, R., 1967. Monographie des Coléoptères Brentidae du Continent Africain. Annales du Musée royal de l'Afrique Central. Série in $8 v o$ (Sciences Zoologiques), 1: 1-507.

Deuve, T. 1988. Les sternites VIII et IX de l'abdomen soint-ils visibles chez les imagos des coléoptères et des autres insectes holométaboles? Nouvelle Revue d'Entomologie (N.S.), 5(1): 21-34.

DuPorte, E. M., 1960. Evolution of cranial structure in adult Coleoptera. Canadian Journal of Zoology, 38: 655-675.

Faust, J., 1890. Die Gattung Sciaphilus Sch. Stettiner entomologische Zeitschrift, 51: 257-252.

Fremuth, J. \& Lodos, N., 1987. Taxonomic position of the genera Aomus Schoenherr and Chilodrosus Reitter (Col.: Curculionidae), with the description of the two new species from Turkey. Turkish Journal of Entomology, 11(2): 73-84.

Girón, J. C. \& Franz, N. M., 2010. Revision, phylogeny and historical biogeography of the genus Apodrosus Marshall, 1922 (Coleoptera: Curculionidae: Entiminae). Insect Systematics \& Evolution, 41: 339-414.
Gómez Zurita, J. \& Galián, J. 2005. Current knowledge on genes and genomes of phytophagous beetles (Coleoptera: Chrysomeloidea, Curculionoidea): a review. European Journal of Entomology, 102: 557-597.

Gosik, R., Hirsch, J. \& Sprick, P. 2010. Biology and molecular determination of Pachyrhinus lethierryi (Desbrochers, 1875) with description of the mature larva and pupa (Coleoptera, Curculionidae, Entiminae: Polydrusini) Snudebiller, 11: 80-95.

Heller, K. M., 1909. Rüsselkäfer aus Erythräa. Wiener Entomologsiche Zeitung, 28(7-8): 233-239.

Heyne, A. \& Tachenberg, O., 1893. Die exotische Käfer in Wort und Bild. Band I. Verlag von G. Reusche. Leipzig. 262 pp. + lám. 30, fig. 7 (II, 1908).

Hlávac, T.F., 1972. The prothorax of Coleoptera: Origin, major features of variation. Psyche, 79(3): 123-149.

Hopkins, A. D., 1909. Contributions toward a monograph of the Scolytid beetles. The genus Dendroctonus. USDA Technical Series, 17(1): 1-164.

Hundsdoerfer, A. K., Rheinheimer, J. \& Wink, M., 2009. Towards the phylogeny of the Curculionoidea (Coleoptera): Reconstructions from mitochondrial and nuclear ribosomal DNA sequences. Zoologischer Anzeiger, 248: 9-31.

Ienistea, M. A., 1986. A new hierarchical system of Arthropoda, mainly referring to insects. YES Quarterly, 3(2): 13-38.

Imms, A. D., 1970. A general textbook of Entomology, including the anatomy, physiology, development and classification of insects. Methuen \& Co Ltd. London. $886 \mathrm{pp}$. (9 $9^{\text {th }}$ edition, revised by O.W. Richards and R. G. Davies).

Jeannel, R. \& Paulian, R., 1943. Morphologie abdominale des Coléoptères et systématique de l'ordre. Revue française d'Entomologie, 11: 65-110.

Katoh, K., Kuma, K., Toh, H. \& Miyata, T., 2005. MAFFT version 5: improvement in accuracy of multiple sequence alignment. Nucleic Acids Research, 33(2): 511-518.

Kuschel, G., 1951. Revision de Lissorhoptrus LeConte y géneros vecinos de América. Revista chilena de Entomología, 1: 23-74.

Kuschel, G., 1995. A phylogenetic classification of Curculionoidea to families and subfamilies. Memoirs of the Entomological Society of Washington, 14: 5-33.

Kuschel, G., 1989. Terminology affecting the Spermatheca. Curculio, 27(January 15): 4.

Lacordaire, Th., 1863. Histoire naturelle des Insectes. Genera des Coléoptères. T. VI. Curculionides. Librairie Encyclopédique de Roret. Paris. 594 pp.

LeConte, J. L. \& Horn, G. H., 1876. The Rhynchophora of America north of Mexico. Proceedings of the American Philosophical Society, 15: i-xvi + 1-455 pp.

Lindroth, C. H. \& Palmén, E., 1970. Cap. 16. Coleoptera. In: S. L. Tuxen (ed.). Taxonomist's glossary of genitalia in insects. Munksgaard. Copenhagen: 80-88. 
Lona C., 1938. Curculionidae: Otiorhynchinae III. In: W. Junk \& S. Schenkling (eds.). Coleopterorum Catalogus. Dr. W. Junk. Gravenhage: 413-600.

Lyal, C. H. C., 1995. The ventral structures of the weevil head (Coleoptera: Curculionoidea). Memoirs of the Entomological Society of Washington, 14: 35-51.

Lyal, C. H. C. (ed.). 2010. Glossary of weevil characters. International Weevil Community Website. http://weevil.info/glossary-weevil-characters (consultada 30.06. 2010).

Machado, A., 2007. New species of Laparocerus Schönherr, 1834 from La Gomera, Canary Islands (Coleoptera, Curculionidae, Entiminae). Zootaxa, 1643: 1-38.

Machado, A., 2008a. Three new endogean species of Laparocerus Schönherr, 1834 from the Canary Islands (Coleoptera, Curculionidae). Journal of Natural History, 43(17-18): 1277-1288.

Machado, A. 2008b. New taxa of Laparocerus Schönherr, 1832 from Madeira and Porto Santo,with a key to the species of the Madeiran Archipelago (Coleoptera, Curculionidae, Entiminae). Graellsia, 64(2): 307-328.

Machado, A. 2009. El género Drouetius Méquignon, 1942 stat. prom., de las islas Azores (Coleoptera, Curculionidae, Entiminae). Graellsia, 65(1): 19-46.

Machado, A., López, M., Almeida, T. \& Hernández, M. 2008. Mitochondrial DNA phylogenetic analysis of the genus Laparocerus (Coleoptera, Curculionidae, Entiminae). I. Zoologica Scripta, 37: 415-427.

Machado, A. \& Morera, M. (eds.), 2005. Nombres comunes de las plantas y los animales de Canarias. Academia Canaria de La Lengua. La Laguna. 277 pp.

Marvaldi, A. E., 1997. Higher level phylogeny of Curculionidae (Coleoptera: Curculionoidea) based mainly on larval characters, with special reference to broad-nosed weevils. Cladistics, 13: 285-312.

Marvaldi, A. E., 1998. Larvae of Entiminae (Coleoptera: Curculionidae): tribal diagnoses and phylogenetic key, with a proposal about natural groups within Entimini. Entomologica scandinavica, 29(1): 89-98.

Marvaldi, A. E., 2003. Key to larvae of South American subfamilies of weevils (Coleoptera, Curculionidae). Revista chilena de Historia Natural, 76: 603-612.

Marvaldi, A. E. \& Morrone, J. J., 2000. Phylogenetic systematic of weevils (Coleoptera: Curculionoidea): A reappraisal based on larval and adult morphology. Insect Systematics \& Evolution, 31(1): 43-58.

Marvaldi, A.E., Sequeira, A.S., Brien, Ch.W. \& Farrell, B. D., 2002. Molecular and morphological phylogenetics of weevils (Coleoptera, Curculionoidea): Do niche shifts accompany diversification? Systematic Biology, 52(5): 761-785.

Matsuda, R., 1970. Morphology and evolution of the insect head. Memoirs of the Entomological Society of Canada, 76: 1-430.
May, B. M., 1993. Larvae of Curculionioidea (Insecta: Coleoptera): a systematic overview. In: C. T. Duval (ed.). Fauna of New Zealand, 28. Manaaki Whenua Press. Lincoln. 226 pp.

McKenna, D. D., Sequeira, A. S., Marvaldi, A. \& Farrell, B. D., 2009. Temporal lags and overlap in the diversification of weevils and flowering plants. Proceedings of the National Academy of Sciences of the United States of America, 106(17): 7083-7088. doi: 10.1073/ pnas.0810618106

Morimoto, K., 1962a. Comparative morphology and phylogeny of the superfamily Curculionoidea of Japan . Journal of the Faculty of Agriculture, Kyûsh $\hat{u}$ University, 11(4): 331-372.

Morimoto, K., 1962b. Key to families, subfamilies and genera of the superfamily Curculionoidea of Japan excluding Scolytidae, Platypodidae and Cossoninae (Comparative morphology, phylogeny and systematics of the superfamily Curculionoidea of Japan. III). Journal of the Faculty of Agriculture, Kyûshû University, 12: 21-66.

Morimoto, K., Kojima, H. \& Miyakawa, S., 2006. The insects of Japan. Vol. 3. Curculionoidea: General introduction and Curculionidae: Entiminae (Part 1), Phyllobiini, Polydrusini and Cuphicerini (Coleoptera). Entomological Society of Japan. Fukuoka. 406 pp.

Oberprieler, R. G., Marvaldi, A. E. \& Anderson, R. S., 2007. Weevils, weevils, weevils everywhere. Zootaxa, 1228: 491-520.

Pierce, W. D., 1913. Miscellaneous contributions to the knowledge of the weevils of the families Attelabidae and Brachyrhinidae. Proceedings of the United Satates National Museum, 45: 365-426.

Scherf, H., 1964. Die Entwicklungsstadien der mitteleuropäischen Curculioniden (Morphologie, Bionomie, Ökologie). Abhandlungen der Senckenbergischen Naturforschenden Gesellschaft, 506: 1-335.

Seidlitz, G., 1868. Die Otiorhynchiden im engeren Sinne eine Gruppe aus der Familie der Rüsselkäfer nach den morphologischen Verwandschaftsverhältnissen ihres Hautscelet's vergleichend dargestellt. Entomologischen Vereine in Berlin. Berlin. 153 pp.

Sharp, D., 1918. Studies in Rhynchophora. IV. A preliminary note on the male genitalia. Transactions of the Entomological Society of London, 1918(I, II): 209-221.

Snodgrass, R. E., 1995. Principles of insect morphology. Cornell University Press. Ithaca et London. 768 pp. ( $1^{\text {th }}$ ed. McGraw-Hill 1935).

Tamura, K., Dudley, J., Nei, M. \& Kumar, S., 2007. MEGA4: Molecular Evolutionary Genetics Analysis (MEGA) software version 4.0. Molecular Biology and Evolution, 24: 1596-1599.

Thompson, R. T., 1989. Terminology of the spermatheca - a protest. Curculio, 26(January 15): 3-4. 
Thompson, R. T., 1992. Observations on the morphology and classification of weevils (Coleoptera, Curculionoidea) with a key to major groups. Journal of Natural History, 26: 835-891.

Ting, P. C., 1936. The mouth parts of the coleopterous group Rhynchophora. Microentomology, 1(3): 93-114.

Torre-Bueno, J. R. d. 1., 1989. The Torre-Bueno glossary of Entomology / compiled by Stephen W. Nichols; including Supplement A by George S. Tulloch. The New York Entomological Society. New York. 840 pp. Edición revisada.

Van den Berg, H. C., 1972. The morphology of Eremnus cerealis Marshall (Coleoptera: Curculionidae). Annale Universiteit Van Stellenbosch, Serie A, 47(1): 1-58.

Van Emden, F. I., 1952. On the taxonomy of Rhynchophora larvae: Adelognatha and Alophinae (Inects: Coleoptera). Proceedings of the zoological Society of London, 122: 651-795.

Velázquez de Castro, A. J., 1998. Morphology and taxonomy of the genus Sitona Germar, 1817. (I): the metendosternite (Coleoptera: Curculionidae). In: E. Colonnelli, S. Louw \& G. Osella (eds.). Taxonomy, Ecology and Distribution of Curculionoidea (Coleoptera: Polyphaga). Proceedings of a Symposium (28 August, 1996, Florence, Italy), XX International Congress of Entomology. Museo Regionale di Scienze Naturali. Torino: 109-123.

Velázquez de Castro, A. J., 2002. The terminology of metendosternite in Coleoptera. Elytron, [2001], 15: 191-194.

Velázquez de Castro, A. J., Alonso-Zarazaga, M. Á. \& Outerelo, R., 2007. Systematics of Sitonini (Coleoptera: Curculionidae: Entiminae), with a hypothesis on the evolution of feeding habits. Systematic Entomology, 32: 312-331.

Wanat, M., 2007. Alignment and homology of male terminalia in Curculionoidea and other Coleoptera. Invertebrate Systematics, 21: 147-171

Winkler, A. (ed.), 1932. Catalogus Coleopterorum regionis palaearcticae. Pars 12. Albert Winkler. Wien. pp. 1393-1520.
Yukanov, N. N. \& Korotyaev, B. A., 2008. On the systematics of the weevil genus Araxia Khnzorian with descriptions of new taxa from Transcaucasia, Turkey, and Turkmenistan (Coleoptera: Curculionidae: Entiminae). Insect Systematics \& Evolution, 39: 39-54.

Zhang, Z., Schwartz, S., Wagner, L. \& Miller, W., 2000. A greedy algorithm for aligning DNA sequences. Journal of Computer Biology, 7(1-2): 203-214. 